796 THE SECRETARY ON ADDITIONS TO THE MENAGERIE. [Dec. 6 ,

\title{
December 6, 1870 .
}

\section{R. Hudson, Esq., F.R.S., in the Chair.}

The Secretary read the following report on the additions to the Society's Menagerie during the months of October and November, 1870 :-

The total number of registered additions to the Society's Menagerie during the month of October was 71 , of which 2 were by birth, 47 by presentation, 5 by purchase, 4 by exchange, and 13 were animals received on deposit. The total number of departures during the same period, by death and removals, was 108 .

The more remarkable animals among the acquisitions were :-

1. Two Red-tailed Guans (Ortalida ruficauda) from Tobago, received October $4 \mathrm{th}$, having been presented to the Society by the Hon. W. J. Buhôt, M.D., M.R.C.S., of that island. These are the first examples of this Guan ever received alive by the Society, but were in very poor condition when they arrived. One has since died; but the other seems likely to recover.

2. A fine specimen of Geoffroy's Cat (Felis geoffroii), purchased October 10th of Capt. E. Hairby, by whom it was brought from Buenos Ayres, with the information that it had been obtained from Paraguay. On the arrival of this animal I identified it from memory with a specimen I had seen in the British Museum, upon which Dr. Gray had established his Leopardus himalayanus (List of Mamm. in B. M. p. 44), and of which he afterwards made a new genus and species under the name Pardalina warwickii*. Mr. Bartlett, having examined the specimen in the British Museum, confirmed my opinion; and I accordingly entered the animal on the register as Warwick's Cat (Felis warwickii $\uparrow$ ).

The so-called Felis warwickii being now dead, I have been able to examine it more carefully, and find it to belong to a well-known South-American species-Felis geoffroii of D'Orbigny and Gervais. This Cat was discovered by D'Orbigny on the Rio Negro, and is well figured and described in the 'Magasin de Zoologie' (1844, Mamm. pl. 57), and in D'Orbigny's 'Voyage' (Mamm. p. 25, tab. 14). In the latter work the skull is also figured (pl. 13. figs. 1, $\mathrm{l}^{\mathrm{a}}$ ). Burmeister (La Plata-Reise, ii. p. 397) tells us that it is found all over the Argentine Republic in the more wooded districts. The native name is "Gato montese" - the Felis pajeros, which we have also lately received alive ( $f f$. P. Z. S. 1868, p. 530) being designated as the "Gato de la pampa."

I have now also myself compared our specimen with the original of Pardalina warwickii in the British Museum, and have no doubt of their belonging to the same species. The skull of our specimen, which was a young although fully grown animal, does not, however,

* Cat. Carn., Pach., and Edentate Mamm. p. 14 (1869).

† See 'Field' for 22nd October, 1870, p. 349. 
quite agree with the skull of Felis warwickii, which is that of a very old individual, being rather shorter (total length from end of præmaxilla to occipital foramen 3.7 inches instead of 4 inches) and considerably narrower in proportion (being only $2 \cdot 6$ inches in extreme width of the zygomata instead of 3.1 inches). But I believe there is considerable variation in the skulls of most species of the genus Felis.

Felis geoffroii seems to be nearly allied to the Ocelot (Felis pardalis); and I cannot understand what claims it has to be regarded as forming a distinct genus.

Dr. Gray refers to his "Pardalina warwickii" Sir William Jardine's figure of Felis himalayanus in the 'Naturalist's Library' (vol. xvi. pl. 24*), stating that the figure in question was taken "from the specimen in the Surrey Zoological Gardens." But Sir William Jardine expressly says that his figure of "Felis himalayanus" is a copy of a drawing by Mr. Lear, taken from a "skin received from the Himalayan district of India ;" and there can be no doubt, I think, that it represents the Viverrine Cat (Felis viverrina, Bennett) of India, of which it is, indeed, a very fair representation.

3. Two Spider Monkeys, purchased October 14th, and stated to have been brought from Nicaragua. One of these belongs to the species called in the Catalogue of Vertebrates (ed. iv. p. 8) Ateles frontatus, Gray $t$, which we have more than once received from the same locality $\neq$. The second Spider Monkey, which has since died, and of which I now exhibit the stuffed skin, is apparently of a different species, and unknown to me. There is, however, a similar example in the British Museum, which is, as I am informed by Mr. Gerrard, the type of a proposed new species of Dr. Gray (Ateles ornatus), to be described in a forthcoming Catalogue of the Quadrumana.

The total number of registered additions to the Society's Menagerie during the month of November was 32 , of which 1 was by birth, 16 by presentation, 7 by exchange, and 8 were animals received on deposit. The total number of departures during the same period, by death and removals, was 118 .

Amongst the acquisitions the only animal worth remark was a female of the Antarctic Wolf (Canis antarcticus), received November 8th. Mr. H. Byng, the acting colonial secretary of this colony, kindly forwarded a pair of these animals as a present to the Society's Menagerie; but one only survived to reach the Society's Gardens. Mr. Byng states that, as Mr. Marwin (Zool. Voy. Beagle, ii. p. 10) prophesied would probably be the case, this animal, formerly so common, has now become almost extinct in the Falklands, the depredations it commits upon the Sheep having rendered its extirpation necessary. The only previous specimen of this animal, as far as I know, was that brought home by Lecomte in 1868 (see P. Z. S. 1868, p. 529).

+ Brachyteles frontatus, Gray, Voy. Sulphur, Mamm. p. 9, pl. 1.

$\ddagger$ See P. Z. S. 1862 , p. 186. 
In concluding my report for these last two months, I must not omit to record the existence in the Gardens during a part of that period of an example of the Ka-ka-po, or Night-parrot of New Zealand (Strigops habroptilus). On the 20th of September Mr. G. S. Sale deposited in the Society's care a specimen of this most interesting bird, and removed it on November 3rd, after some unavailing attempts to come to terms with us as to its price. A good illustration of the Kakapo, taken from this bird, was given in the 'Field' for 15 th October, 1870 (p. 328); and at p. 411 (November 12th) will be found a notice of its habits by the owner.

The Secretary read the following extract from a letter addressed to him by Dr. R. C. Cunningham, C.M.Z.S., concerning a specimen of the Manatee (Manatus americanus) kept alive in captivity :-

"The specimen of the Manatee observed by me at Rio in 1867 and 1869 had been procured, as I was informed, from the Amazons, and was kept in a strip of artificial water in the Passao Publico (Public Gardens) of the city, which was tenanted also by two young Jacares and a variety of water-fowl. It measured, as nearly as I could calculate, between 4 and 5 feet in length. In general it could only be recognized as an inky shadow moving along at some distance below the surface of the water. It evinced a curious predilection for the society of a white Swan, following this bird, which was not at all alarmed by its associate, from place to place, so that we found that the presence of the Swan on any particular spot on the water was a guide to that of the Manatee, or ' $\mathrm{Cow}$-fish' as it is generally termed by the inhabitants of Rio. It was very tame, often protruding its curiously fringed lips above the surface of the water to take bunches of grass from the hands of the bystanders; and several times I observed it grazing on the short herbage at the sides of the water. This it accomplished by raising its head and shoulders above the surface, and maintaining itself in this position by means of one pectoral fin placed on the top of the low stone ledge or parapet which separated the water from the adjoining turf, while it slowly moved along sideways in this position, cropping the grass as it went."

The following (ninth) letter upon the ornithology of Buenos Ayres, by Mr. W. H. Hudson, C.M.Z.S., was read*:-

“Buenos Ayres, June 20th, 1870.

"We are now near the winter solstice, and the weather has become exceedingly mild. This short period of pleasant weather in midwinter is called in Buenos Ayres 'Veranillo de San Juan,' and is experienced here almost every season. So warm have the last few days been, that the Dusky Thrush (Turdus leucomelas) has been heard frequently, though his full delightful song is never put forth till September; but the Cardinal, Black-headed Finch, and Calandria have been singing as if it were really spring.

$$
\text { * For Mr. Hudson's last letter see anteà, p. } 748 .
$$


"I have only been able to obtain three specimens of the Molothrus rufo-axillaris since receiving your letter asking for some skins of that species : they all proved males; so I shall keep them for you until I have samples of both sexes. I am not yet very well acquainted with the breeding-habits of this bird, but, from what I have observed, strongly suspect that it is polygamous. If this is true, it is a wonderful circumstance that the three Molothri of Buenos Ayres should differ from almost all other birds in their weakness or total want of sexual attachment. I hope in summer to be able to discover some additional facts concerning the $M$. bonariensis, also to collect for you some of their eggs, which I am sure you will think interesting curiosities.

"Winter and resident game birds are uncommonly plentiful this season, affording me a good opportunity for securing specimens and observing their habits. As I am fond of gunning, the Duck and Snipe families are favourites. Of the Scolopacida family I am acquainted with twenty species. Seventeen of these are well known to naturalists, or at least have had their affinities determined; but before writing much about them I should like to become more familiar with some of their habits, especially the times of their arrival and departure, also the nidification of the resident species. The other three are perhaps not known, or not considered natives of this region. I have formerly shot, but never preserved, specimens of two of them. But I will say no more at present about these birds, as memory is not a faithful guide in such matters, and some favourable chance may bring them in my way again.

"It is a remarkable circumstance that the three birds that possess perhaps the widest range of all the species belonging to the fauna of Buenos Ayres should have been uncommonly abundant this autumn. These birds are the Himantopus nigricollis, a native of both Americas ; the Otus brachyotus, called here 'Lechuson,' and known, I believe, in Asia and Europe as well as in America; and the Glossy Ibis (Ibis falcinellus), a bird possessing a still wider range. The Black-necked Himantopus, though almost unfailingly found wherever much water occurs on the pampas, is not a numerous species; but at present they are extremely abundant, and quite familiar even in cultivated fields near the farmhouses, flocks of them being seen wherever little pools of water have been formed by the rains. At some future time I will communicate all I have learned from personal observation respecting its habits. Whether the habits of a species (like this bird) distributed over an entire continent become modified by circumstances in the widely separated regions they frequent, or not, must be an interesting subject of inquiry to naturalists.

"The Glossy Ibis is very common all over the State of Buenos Ayres. They appear in spring; but as their movements are very irregular, and many individuals remain through the winter, their migrations are probably not altogether dependent on atmospheric changes. They have a graceful flight; and when migrating, the flocks are seen to succeed each other in rapid succession, each flock being usually composed of from fifty to a hundred individuals, but 
sometimes of a much greater number. A body of these birds on the wing is a most interesting sight-now soaring high in the air, displaying the deep chestnut hue of their breasts, now descending with a graceful curve towards the earth, as if to exhibit the beautiful metallic green of their upper plumage. The flock is in the mean time continually changing its form or disposition, as if at the com. mand of a leader. One moment it spreads out in a long straight line; suddenly the birds scatter in disorder, or throw themselves together like a cloud of Blackbirds; as suddenly they again re-form and proceed in the figure of a phalanx, half-moon, or triangle. The fanciful notion will scarcely fail to suggest itself to the beholder's mind, that the birds go through these unnecessary evolutions intelligently to attain greater proficiency in them by practice, or merely to make a display of their aërial accomplishments. The Ibis has another remarkable habit while flying; it is not, however, a habit exclusively confined to this species. The flock is sometimes seen as if seized with sudden frenzy or panic, every bird rushing wildly away from its fellows, and descending with a violent zigzag flight; in a few moments the mad fit leaves them, they rise again, reassemble in the air, and resume their journey.

"I should like to know if any thing has been recorded concerning the nidification of this bird. Having the four quarters of the globe for an habitat, perhaps it is in no country more common than in this; yet its only breeding-place here that I have yet heard of is the Gualicho, a marshy district about 170 miles south of Buenos Ayres city. I have not visited this place in the breeding-season, but have been told by people living in its vicinity that the Ibises breed there in great numbers, and make their nests close together. The nest is made of dry grass on the ground; the eggs are blue, and three in number. Baird, in his 'Synopsis of North-American Birds,' says nothing is known of its nidification ; but this may refer to the bird only in North America. I hope from my own observation to find out something more of its breeding-habits in this country. The Lechuson (Otus brachyotus), though, like the preceding species, pretty generally distributed over the pampas, was, until within the last three years, rather a scarce bird. It breeds on the ground, makes no nest, but merely clears and presses a circular spot on the ground among the loose tussocks of long grass, and lays four white eggs of a slightly oval form. Near sunset the Lechuson is seen quitting its concealment and sitting perched upon a thistle or other eminence, or sailing above the ground with a slow Heron-like flight; at intervals while flying it strikes its wings together under its breast in a very sudden, quick manner. It is not at all shy, the intrusion of a man or dog at evening in the field it frequents appearing greatly to excite its indignation. An imitation of its cry will attract numbers of them about a person; the report of a gun has the same effect. The language of this species has considerable variety; when alarmed or angry they utter a loud sharp hiss, and at times a sudden shrill laugh-like cry. They have also a dismal hollow scream, not often heard, and at twilight hont-this part of their vocal perform- 
ances sounding not unlike the distant baying of a 'deep-mouthed' watch-dog.

"The late great increase of the large Owls in this neighbourhood can only be ascribed to the recent cultivation of the plains near the city. Within the last six years a great extent of hitherto bald shelterless grounds have been enclosed, and are now yearly planted with wheat and maize; in the fields the Owls find shelter, and their favourite food in abundance, Mice, Partridges, \&c.

"The Lechuson frequenting open plains in preference to woods, and hiding by day on the ground, has the colour of its plumage adapted to a country like the desert pampas, rough with a brown vegetation. But the introduction and increase of Sheep quickly changed the aspect of a vast extent of the plain; the long brown grasses disappeared, their place being taken by a tender herbage, short and brilliant green; the country was thus unfitted for their pasturage. All the wild animals have, no doubt, been greatly affected by this sudden change in vegetation and total destruction of cover. But cultivation has now partially restored the physical conditions necessary to the preservation and increase of many species like the Lechuson. In future descriptions I shall frequently refer to these changes on the pampas.

"The gradual increase or diminution constantly going on in many species about us is little remarked; but the sudden appearance in vast numbers of a species not usually common is regarded by all with interest and wonder. When, owing to a season favourable to propagation, a small species multiplies greatly (as often happens here with Mice, Toads, Crickets, \&c.), we may confidently look for the appearing of multitudes of those birds that subsist on them. Thus, in the year 1856, when the earth swarmed with Mice, vast numbers of the then scarce Lechuson, and flocks of the Great Adjutant Stork (Mycteria americana) also appeared. Armies of these majestic white birds were seen stalking over the grass on all sides, or at the close of day winging their flight to the distant watercourses in a continuous flock; while the night air resounded to the solemn hootings of the innumerable Owls. However simple may be the cause of the first phenomenon (the sudden great increase of a species incapable of migration but exceedingly prolific), the attendant one appears to have been remarked with astonishment from very early times, and to have given rise to many conjectures. Pliny, if I remember right, relates that one season in some part of Asia Minor the Mice increased in an extraordinary manner, but soon appeared ' an army of strangely painted birds' and devoured them all. Birds of prey and those that subsist on large insects, and possess great powers of flight, without being strictly migratory, when not occupied with the business of propagation, are incessantly wandering in quest of food. They often fly high, and traverse vast distances. When the natural food of any one of such species abounds very much in a particular region, all the birds that discover it remain in it and continually attract to them all of their kind passing over them. It 
thus happens here with the large Owl, the Adjutant, and other species that fly singly or in small flocks : a few first appear like harbingers ; these are soon joined by new comers in considerable numbers; and before long they are in myriads. Inconceivable numbers of birds are, no doubt, continually passing over us unseen. It was once a matter of wonder to me that flocks of Swans should almost always appear flying past after a shower, even when none had been visible for a long time before, and when they must have come from great distances. But the simple reason soon occurred to me, that after rain a Swan may be visible at a vastly greater distance than during fair weather, the sun shining on its snow-white plumage against the dark background of a cloud rendering it very conspicuous. The fact of Swans being seen almost always after a rain is only a proof that they are almost always passing. Whenever we are visited by a great dust-storm, myriads of Gulls appear flying before it; this is invariably the case even when not a Gull has been visible for months. A dust-storm is always preceded by long drought, so that from the watercourses being all dry the Gulls could not well have subsisted in the region over which it passes. Yet in seasons of drought Gulls must be incessantly passing over us, visible only when driven together and forced towards the earth by the violence of the storm. The bird I allude to is the Black-headed Gull (Larus cirrhocephalus). In seasons when Grasshoppers abound very much, flocks of these birds also appear, often in such multitudes as to free entire districts from the devastating swarms of the hated insects. It is a fine sight, and a welcome one as well, to see a flight of these birds settle on the afflicted district; at such times their mode of proceeding is often so regular, that a body of them well deserves the appellation of ' an army of birds.' They come down with a swift graceful flight, and settle on the earth with loud joyful cries, but do not abandon when the work of devouring has begun the order in which the flock was disposed. It often presents a front of several thousand feet, with a breadth of but sixty or eighty; all along this line of battle the excited cries of the innumerable birds produce a loud, incessant noise. Every bird is incessantly on the move-some skimming along the ground with half expanded wing, others pursuing the fugitives through the air; and all the time the hindmost birds are flying over the flock and alighting in the front ranks; so that the whole body is steadily advancing, and leaving the earth over which it passes free from the pest. The Black-headed Gull is one of our most common birds, and has many very interesting habits; I hope before long to make it the subject of another letter.

$$
\begin{aligned}
& \text { "I remain, Sir, } \\
& \text { "Truly yours, } \\
&
\end{aligned}
$$

Dr. J. Murie read the second part of his memoir on the Anatomy of the Sea-lion (Otaria jubata). The present portion treated of the skeleton and nervous system, vascular and respiratory organs, di- 
gestive system, and urino-generative organs of this animal, as observed in the male specimen which died in the Society's Gardens in $1870^{*}$.

This paper will be published in the Society's 'Transactions.'

Mr. Gould brought under the notice of the Meeting two species of Humming-birds, which he believed to be new to science, and for which he proposed the names of Chatocercus bombus and Thalurania hypochlora. They formed part of a collection made by $\mathrm{Mr}$. W. Buckley in the temperate parts of Ecuador during the autumn of the present year, 1870. This collection was remarkable for the absence of many of the species, and even of the forms, inhabiting the high lands around Quito, and for the presence of others which are mostly found in Venezuela, Veragua, and Costa Rica.

The collection comprised about 130 specimens of thirty species, of which the following was a list, with the localities wherein they were obtained :-

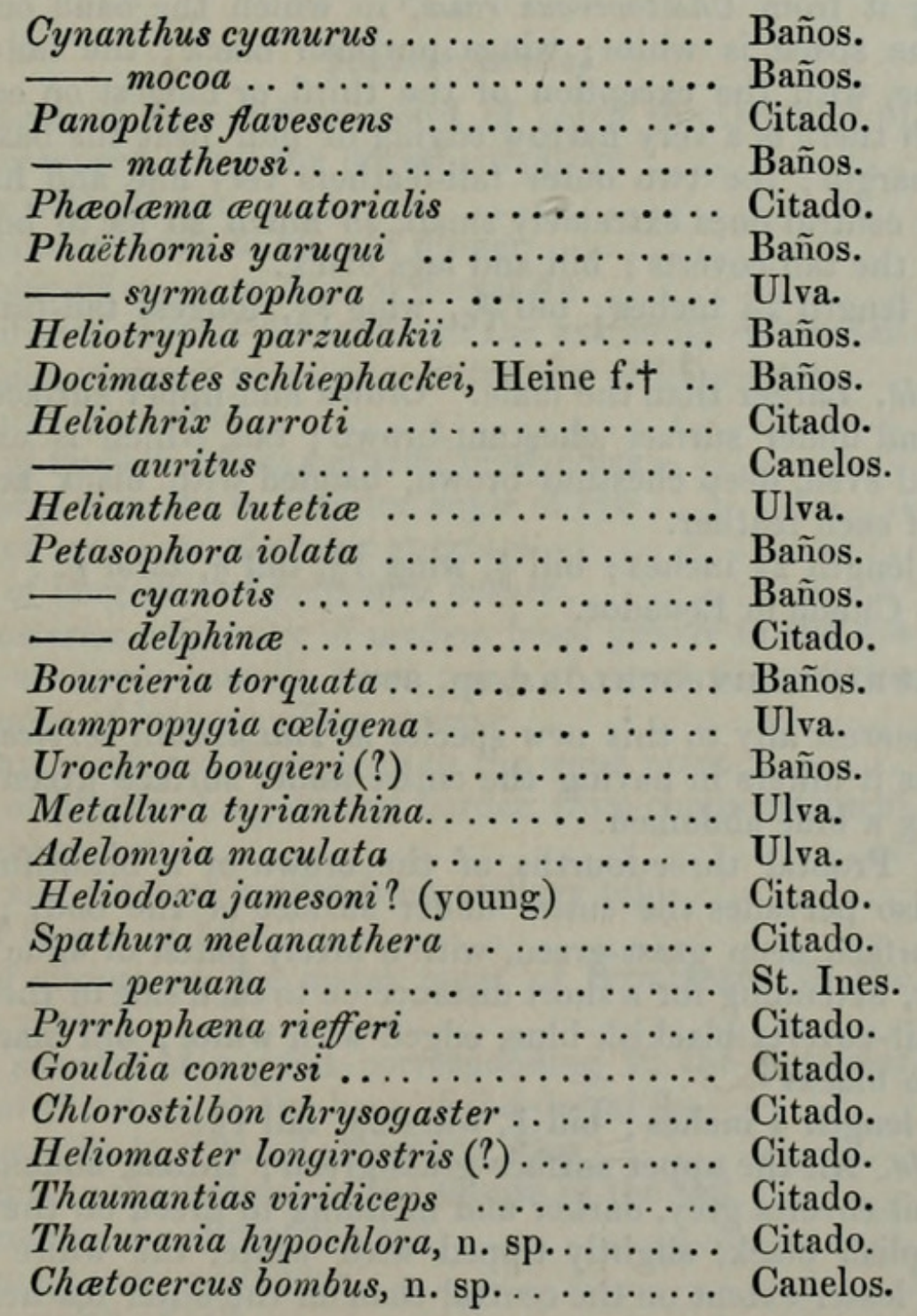

Mr. Gould eulogized the zeal and perseverance displayed by Mr.

* See P. Z. S. 1867, p. $243 . \quad$ † Journ. f. Orn. 1863, p. 215. 
Buckley in having collected so many species during the very short time he had been in the country, and gave the following descriptions of the two new species :-

\section{Chetocercus bombus, sp. nov.}

This species must be classed with the most diminutive of the Trochilidæ. In its general appearance and in its coloration it strongly reminds one of Chatocercus rosa, while, in some parts of its structure, particularly in the form of its two hair-like outer tailfeathers, it resembles Acestrura mulsanti; its wing is even smaller and shorter than that of the little A. heliodori. It must, however, be placed, as I believe it is correctly, in the genus Chatocercus.

The following is a more minute description and admeasurement of this little bird.

Male. Crown of the head, upper surface, and abdomen bronzy green ; throat brilliant crimson-red, nearly surrounded by a mark of buff, forming a conspicuous band across the chest, a feature distinguishing it from Chretocercus rosa, in which the band occupying the same space is white; wings purplish black; the tail-feathers the same, with the exception of the third or longest on each side, on which there is a very narrow edging of buff near the base of the inner margin; the two outer tail-feathers very fine and hair-like; the four central ones extremely small, so much so as to be hidden beneath the tail-coverts; bill and legs black.

Total length $2 \frac{1}{2}$ inches; bill $\frac{9}{16}$, wing $\frac{15}{16}$, longest tail-feathers $\frac{3}{4}$, $\operatorname{tarsi} \frac{1}{8}$.

Female. Larger than the male. Crown and upper surface green; throat and under surface chestnut-brown; tail, which is extremely short and even, deep chestnut-brown, banded with black across the centre of each feather.

Total length $2 \frac{1}{2}$ inches; bill $\frac{5}{8}$, wing $1 \frac{1}{8}$, tail $\frac{1}{2}$, tarsi $\frac{1}{8}$.

$\mathrm{Hab}$. Citado in Ecuador.

Thalurania hypochlora, sp. nov.

The nearest ally to this new species is Thalurania verticeps; but from this it differs in having the entire under surface green instead of having a blue abdomen.

Male. Frontal three-fourths of the crown of a beautiful green, which also pervades the entire under surface of the body; all the upper surface deep grass-green, with a lovely patch of blue on the shoulder, extending for a short distance on to each side of the breast; under tail-coverts blackish blue, edged with white; bill black; feet brownish black.

Total length 4 inches ; bill $\frac{7}{8}$, wing $2 \frac{1}{8}$, tail $1 \frac{3}{8}$.

Female. All the upper surface grass-green; throat, abdomen, and under tail-coverts grey, darker and inclining to green on the flanks; tail purplish black, slightly tipped with white, the white tipping being of lesser extent on the central than on the outer feathers.

Size rather less than that of the male.

$H a b$. Citado in Ecuador. 
The following papers were read :-

1. Notes on the Anatomy of Balcenoptera rostrata. By J. B. Perrin. (Communicated by Prof. Flower, F.R.S., V.P.Z.S.)

A young female specimen of this species, captured in April 1870, at Weymouth, was purchased by Mr. Gerrard of Camden Town, and removed to the dissecting-room of the Zoological Society, where, by permission of the Council and through Professor Flower's kindness, I had the opportunity of dissecting it. With his valuable assistance have I been enabled to make the observations embodied in the following communication.

The anatomy of this species has been so fully described in the Monograph of Carte and Macalister* that it will be only necessary to mention certain peculiarities which this specimen presented.

The following are the principal external measurements :-

\section{Measurements.}

Total length of animal from point of snout to extremity of tail, measured along the dorsal curvature ......... $13 \quad 8 \frac{1}{2}$

Ditto, in straight line ..................... $13 \quad 5$

From point of snout to base of flipper $\ldots \ldots \ldots \ldots \ldots \ldots, 4 \quad 1$

From point of snout to base of dorsal fin ........... $941 \frac{1}{2}$

From anterior part of dorsal fin to the extremity of the tail $4 \quad 7$

From point of snout to anterior extremity of blow-hole.... 110

Length of blow-holes .................... 0

Length of median sulcus between blow-holes ..........

From point of snout to anterior angle of eye .......... $2 \quad 7 \frac{1}{2}$

Length of long axis of ocular aperture $\ldots \ldots \ldots \ldots \ldots \ldots, 0.62$

Length of long axis of palpebral fissure........... 0

From posterior extremity of median basal groove to the eye $\quad \begin{array}{lll}1 & 1 \frac{3}{4}\end{array}$

Length of upper maxilla from point of snout to posterior extremity of intermaxillary groove

Lower jaw measured from apex to the same point.......... $33_{3} \quad \sigma_{2}$

Length of flipper along ventral border, from commencement of basal groove ................................. $2 \quad 2 \frac{1}{2}$

Length along dorsal border from axillary fold $\ldots \ldots \ldots \ldots$ l $\quad 9$

Girth of flipper at base $\ldots \ldots \ldots \ldots \ldots \ldots \ldots \ldots \ldots$ l $1 \frac{1}{4}$

Girth of flipper at the distal point of termination of the white zone

Anus is situated at a point corresponding to the posterior part of the ridge at the base of the dorsal fin.

The mammilla is situated above the anus $\ldots \ldots \ldots \ldots \ldots, 00 \ldots 1 \frac{1}{2}$

From anus to the bottom of the fissure in the tail........ $3 \quad 6 \frac{1}{2}$

From anus to the end of the tail $\ldots \ldots \ldots \ldots \ldots \ldots \ldots, 38$

From anus to the umbilicus $\ldots \ldots \ldots \ldots \ldots \ldots \ldots \ldots, 24$

Extreme width of tail $\ldots \ldots \ldots \ldots \ldots \ldots \ldots \ldots \ldots \ldots, 3 \quad 8 \frac{1}{2}$

* Philosophical Transactions, 1868, p. 201. 
From termination (apex) of dorsal spinous ridge to the apex

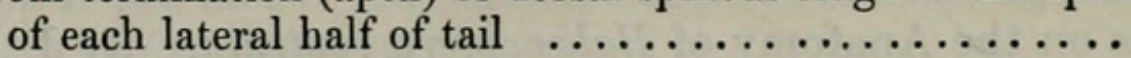

Depth of fissure in tail

ft. in.

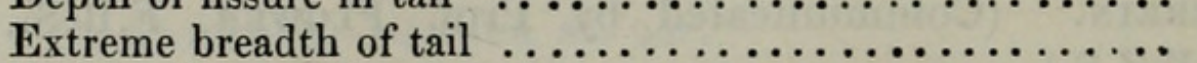

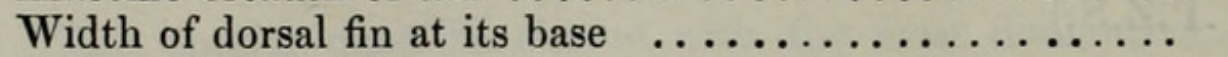

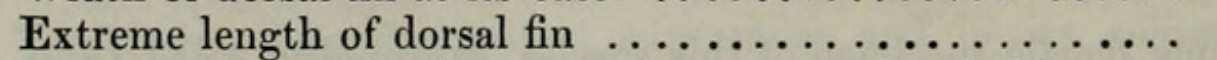

Height of dorsal fin from apex to posterior basal ridge....

Girth of trunk opposite the bases of the flippers (underneath

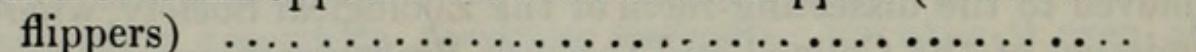

Girth in front of dorsal fin .......................

Girth 1 foot from base of tail . ...................

Girth 2 feet in front of dorsal fin, i. e. about midway between dorsal fin and flipper....................

Length of baleen, measured along its outer side (from base to point of termination in median line in front) .........

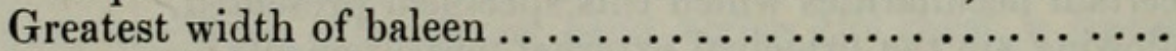

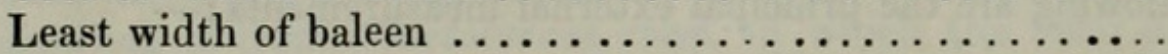

Number of plates in each lateral half of baleen 330 ; total 660 .

A line drawn transversely across between the anterior angles of the eyes crosses the summit of forehead $2 \frac{1}{2}$ inches from posterior extremity of median nasal groove.

Distance from posterior extremity of blow-hole to this transverse line .......................... $003 \frac{1}{2}$

Width from eye to eye..................... $2 \quad 2$

The groove between the blow-holes measured 7 inches, projecting an inch in both the anterior and posterior directions beyond the blow-holes. In the specimen described by Carte and Macalister the nasal groove commenced an inch in front of the anterior commissures of the blow-holes, and fell short of their posterior commissures by about the same distance. The posterior extremity of each blow-hole was wider than the rest of the groove, and the marginal commissures in this situation were marked by rugæ or folds. No hairs were discernible on the nasal commissures. There were, however, two small hairs on the integument covering the apex of the lower maxilla, which could be distinctly seen. The auditory apertures could not be found.

The palpebral fissure extended for a considerable distance both forwards and backwards beyond the ocular aperture, the anterior portion extending a little more than 2 inches, the posterior a little less than 1 beyond it.

The lower jaw projected $1 \frac{3}{4}$ inch more forward than the upper on snout.

The integument covering the whole of the dorsal surface of the animal was of a dusky black, whilst that of the ventral surface was white intermingled with pink, the latter approaching here and there to an almost red colour. This was probably due to exposure to the air. This difference in colour of the integuments on the two surfaces of the body gave a remarkably beautiful appearance to the 
animal, which was still further increased by the ribbed arrangement of the skin on the anterior half of the ventral aspect. This ribbed arrangement was produced by numerous longitudinal furrows or sulci, which penetrated fully a quarter of an inch in depth into the skin, and ran in a more or less regularly parallel manner from before backwards, thus dividing the integument into striæ. These striæ were limited laterally by a line drawn from the angle of reflection of the jaws to the base of the flippers, in which situation they were short and somewhat arched. The striæ commenced in front at the lower jaw, extending its whole length. They were wider both at their commencement and at their termination than in the rest of their course. The median striæ were smaller than the lateral, and more uniform in width throughout their entire length, measuring about half an inch, and sometimes a little more or less; whereas the lateral striæ at origin and termination measured from $1 \frac{1}{4}$ to $1 \frac{1}{2}$ inch. Posteriorly they terminated in a radiate manner, those in the middle line of the ventral surface being the longest, the remainder gradually shortening as they approached the lateral aspect of the trunk. The sulci or grooves in the median line presented some difference from those more laterally situated. Thus the former terminated more gradually than the latter, and resembled a cut made into the skin by an inexperienced operator; the lateral sulci terminated sharp and abruptly. These plicæ or folds did not decussate, or decrease in number in their transit from before backwards, as mentioned in Carte and Macalister's specimen; they were continuous and well marked throughout. The sulci were wedge-shaped, and not quadrilateral as shown diagrammatically by Hunter; no doubt, if the integument were considerably distended they would present that appearance.

The flipper was traversed about the middle of its entire circumference by a zone of white, which contrasted strongly with the slaty black which extended along its basal extremity for about eight inches, and for the same distance along its distal end. This white zone at the basal end was limited by a sharp and abrupt line of termination directed obliquely from before backwards. Distally it terminated in a radiate manner, the white becoming gradually lost in the black.

The ventral surface of the tail was likewise covered with white integument, except at the margins, where the white and black gradually merged into each other.

The Cranio-mandibular Articulation.-This articulation presented several remarkable and interesting features. It was effected by means of a huge fibro-elastic mass, spheroidal in shape and closely adherent by both of its extremities to the squamosal posteriorly, and the condyle of the mandible anteriorly. A small portion, however, of the concavity of the squamosal was free, the cartilage being unattached, as ascertained by making an artificial opening; the finger could be readily passed for a short distance underneath. There was not the slightest trace of a synovial membrane even here; and the close adherence of the elastic mass to the rest of the squamosal, on the one hand, and the globular head of the mandibular arch on

Proc. Zool. Soc.-1870, No, LIV. 
the other, altogether precluded the possibility of such a membrane existing in these situations. The object of the laxity of the fibrocartilage at the squamosal concavity was evidently to allow of the passage of a strong ligamentous band from the under surface of the cartilage to the depression in the squamosal, also to allow of the transmission of vessels.

On the inner side the elastic fibro-cartilage projected beyond the squamosal, and was firmly attached to a strong zone or belt, of a more dense fibro-cartilaginous material, which surrounded the tympanic bone, affording to them an efficient retentive as well as protective nidus. On removing the articular mass, the tympanic zone could be well seen; it was broader on the inner than on the outer side of the ossicle, and broader behind than in front. In the former situation it measured $2 \frac{1}{4}$ inches from before backwards; in the latter 2 inches, whilst its width on the inner side was only one inch. In the centre of this nidus the oval under surface of the tympanic bone could be seen to the extent of two and a quarter inches, measured in its long axis, and one inch and three-quarters measured transversely.

The superficial or circumferential fibres of the articular cartilage at the maxillary end were prolonged forwards on to the circumference of the mandibular condyle, forming a capsular-like belt of attachment, thereby materially adding to the fixity of the cartilage. The fibro-elastic cartilage was still further protected by a dense ligamentous band which passed, from the squamosal to the maxillary condyle, along its under surface. Surrounding it was a dense mass of connective tissue, in which ramified an intricate plexiform network of vessels and nerves. Imbedded in this connective tissue, on the inner side, was a small wedge-shaped muscle, about $3 \frac{1}{2}$ inches long, arising tendinous from the osseous ridge leading from the condyle to the inferior dental foramen. It was about half an inch wide, and terminated in a fascial expansion which was inserted into the fibro-cartilage upon its upper and inner side. The action of this muscle seems to have been to draw the articular mass forwards and inwards, thereby limiting the outward tendency it would otherwise have when the lower jaw was approximated to the upper, and also concentrating the cartilage in the axial line of the mandible during that movement.

The cartilage weighed, when removed, $2 \frac{1}{4} \mathrm{lbs}$. Its circumference measured $17 \frac{1}{2}$ inches. Its maxillary extremity measured transversely 4 inches, and $2 \frac{3}{4}$ inches from above downwards. Its squamosal end measured 5 inches laterally, and $4 \frac{1}{2}$ from above downwards. It presented the well-marked shape of the squamosal articular surface, namely concavo-convex, the concavity being situated antero-internally, the convexity postero-externally. Its length was $4 \frac{I}{2}$ inches.

This articulation is a true amphiarthrosis, exactly analogous to that between the vertebral segments of the human subject, minus the pulp.

The muscles of mastication were moderately well developed, being short, thick, and strong, and so closely approximated to the articular 
cartilage as to afford a still further protective shield to it. These muscles presented no difference from the very accurate description given of them by Carte and Macalister, except that the internal pterygoid was present, arising posterior and internal to the external pterygoid, and inserted anterior and internal to it, thus closely imitating the disposition of the corresponding muscle in the human subject. It was thin and small comparatively to the external pterygoid.

The Pelvic Bones.--These were two in number, both in a cartilaginous condition, situated immediately above and on each side of the anal aperture, the inner extremity of the base of each being distant only an inch and three-quarters from it; they were asymmetrical, the right being a quarter of an inch longer than the left, owing to its anterior extremity being more pointed and prolonged a little more forwards. Both presented two flattened surfaces, two borders (an internal, concave, and an external, convex at its upper and concave at its lower part), and two extremities (an anterior pointed, and a posterior broad and directed obliquely from without downwards and inwards towards the anal aperture). At the summit of the outer convexity there was a small rough fibrous mass, about the size of a pea, in which were imbedded a number of very small cartilaginous plates. This is evidently the rudimentary representative of the femur. It is an easy matter to overlook this little mass, if attention is not particularly directed to it.

Both of these cartilaginous pelvic bones were enveloped in a dense fibrous capsule, which, stripped off, exhibited about the middle a prominent pinkish-red spot, studded over with minute puncta vasculosa. In the left one only was there a decided centre of ossification. The right was entirely cartilaginous.

Both of these rudimentary pelvic bones were imbedded in a mass of muscular tissue, so that care was required to detect them.

The heart and great vessels, except that the former was more median in position and flattened, presented a similar disposition to those of the human subject. The weight of the heart was about $100 \mathrm{oz}$. The walls of the left ventricle were an inch and a quarter thick, whilst those of the right ventricle were only about half an inch. In the right ventricle there was a very prominent fleshy column, situated on its inner wall, and about half an inch thick. It traversed the long axis of the ventricular cavity. From the middle of this column a second or transverse one arose, which crossed the middle of the cavity to the right wall, where it divided into a number of smaller columns, continuous with those on the posterior wall. The pulmonary artery was very large; its diameter measured $3 \frac{1}{4}$ inches in the interior, readily admitting a circular disk of this size without any distention. Its walls, however, were very thin in comparison with those of the aorta.

The pulmonary semilunar valves were large. The right one had a small nodule of Arantius, the rest being destitute of it.

The aorta, at its origin from the left ventricle, was two inches in diameter. As it approached the part from which the innominate 
artery was given off, it underwent some increase in size, and became diminished again below the origin of the left subclavian.

The diameter of the interior of the artery measured only an inch and a quarter, the remaining three quarters of an inch being occupied by the walls.

The inferior wall of the aortic arch presented a remarkable increase in thickness from that of the rest of the tube, at the point opposite the orifice of the innominate artery, being fully half an inch in thickness. The thickness is obviously to prevent yielding at this part, which otherwise would be a weak point, and liable to aneurismal dilatation from the constant shocks which would be communicated to it by the pressure from the recoil of blood from the right aortic wall.

The posterior wall of the arch of the aorta was traversed by numerous irregularly longitudinal striæ, which extend as far as the origin of the left common carotid artery. From these striæ it can be easily inferred that the aorta is subjected to considerable dilatation at each ventricular systole.

The Lungs.-The left lung measured, in its long axis, 23 inches, the right 21 inches. The left lung weighed $6 \frac{1}{2} \mathrm{lbs}$, the right $5 \mathrm{lbs}$. Both lungs were very much congested, especially the left one. Neither presented any lobular divisions.

The trachea was remarkably short, but very wide and flattened. It gave off a small additional bronchus on the right side, to the the upper part of the right lung.

Alimentary Canal.-The stomach consisted of four irregular cavities. The outward configuration of each varied cousiderably, especially of the first and second. The former presented a fusiform shape, being much wider at the centre than at its apex and œsophageal extremities. It measured, when moderately distended with water, 22 inches in its long diameter, and 11 inches transversely at its widest part. The œsophagus entered the upper part of its dorsal aspect, the upper end projecting upwards beyond the point of junction of the gullet, and formed a continuous fence or band with the second stomach. Below it tapered to a blunted point.

The second stomach was cylindrical in shape, being directly continuous at its anterior part with the first stomach, the two being united at an acute angle, and forming a V-shaped figure, the apex being directed upwards towards the diaphragm, and then the two diverging away from each other, the latter, or second stomach, projecting somewhat beyond the first, and presenting a more regular calibre throughout its entire length, terminating, however, below in a blunted and somewhat rounded point. It measured in its long diameter, from the angle of junction between it and the first stomach, 17 inches.

The third stomach was smaller than either of the preceding, and directed more obliquely. It was attached to the middle of the right side of the second stomach, and presented an elliptical shape. It measured 13 inches in its long diameter. It was connected with the second stomach by a strong band of fascia, which passes between the adjacent sides of the second and third stomachs.

The fourth stomach was directed more horizontally than the pre- 
ceding, and was of a rounded or globular shape. It measured 6 inches in its long diameter, or somewhat less than half the diameter of the third stomach. It had, arising from the middle of its dorsal aspect, in an infundibuliform manner, the duodenum, or commencement of the small intestines.

The girth of the first stomach at its middle or widest part measured 30 inches, that of the second 22 inches, the third 21 inches, and the fourth $18 \frac{1}{2}$ inches.

On opening the stomachs there was found in the first ten small pebbles, and in the second also ten others. All the stomachs were perfectly empty in other respects.

The mucous membrane presented different characters in each of the four stomachs. In the first it was of a pearly pinkish-white hue, complexly convoluted, the convolutions being continuous from the longitudinal rugæ of the œsophagus. In the second stomach the colour of the mucous membrane was pale brown, the rugæ running in a transverse direction, and in the upper and lateral walls presenting large and small alternations, the large ones projecting very prominently in the interior of the cavity. At the distal end the rugæ were almost absent.

In the third and fourth stomachs the mucous membrane was of a pale creamy-yellow colour; the rugæ scanty and irregular

The aperture between the first and second stomachs is very large, and readily allows of the passage of materials from one to the other. The aperture between the second and third stomachs is circular, and guarded by an annular, prominent valve. The diameter of this opening is about two inches, the canal afterwards becoming convoluted, and, at its entrance into the third stomach, again undergoes dilatation. The latter aperture is also guarded by an annular valvular fold. The length of this canal is about $2 \frac{1}{2}$ inches long. The aperture between the third and fourth stomachs is small and semilunar, and directed transversely. The fourth stomach passes directly into the intestine, the only lines of demarcation between the two being the abrupt termination of the large calibre and the presence of valvulæ conniventes.

The intestines measured 72 feet 2 inches from the commencement of the duodenum to the cloaca. The large intestine occupied only 5 feet 4 inches of the length. From the commencement of the duodenum to the first diverticulum, a little sac-like dilatation of the small intestine, measured 43 feet 5 inches.

Kidneys :-Weight $=2 \mathrm{lbs} .1 \mathrm{oz}$; ; length 15 inches; width across, or transverse measurement, $=5$ inches; shape fusiform. Surface mapped out into comparatively regularly polygonal-shaped spaces, giving to the kidney a beautiful lobulated character. The diameter of the lobules varied from $\frac{6}{8}$ to an inch. The lobules could be readily isolated, being connected together by a very thin, delicate areolar tissue. The liver was similar in every essential particular to that of Carte and Macalister's specimen.

Muscles of the Shoulder and Extremity.-These presented some few differences from those described by Carte and Macalister. 
Mr. J. B. PERrin ON BALENOptera rostrata. [Dec. 6,

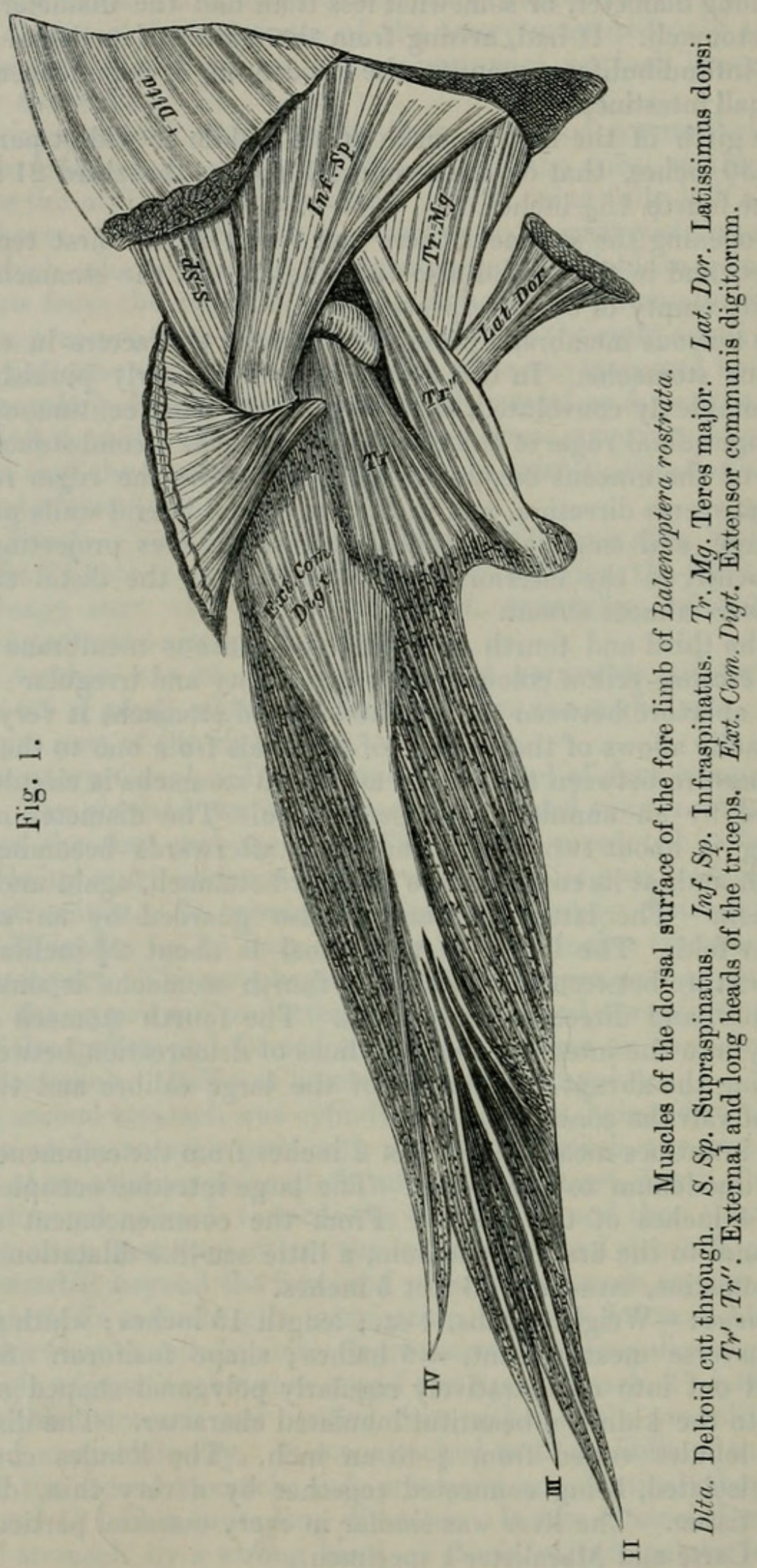




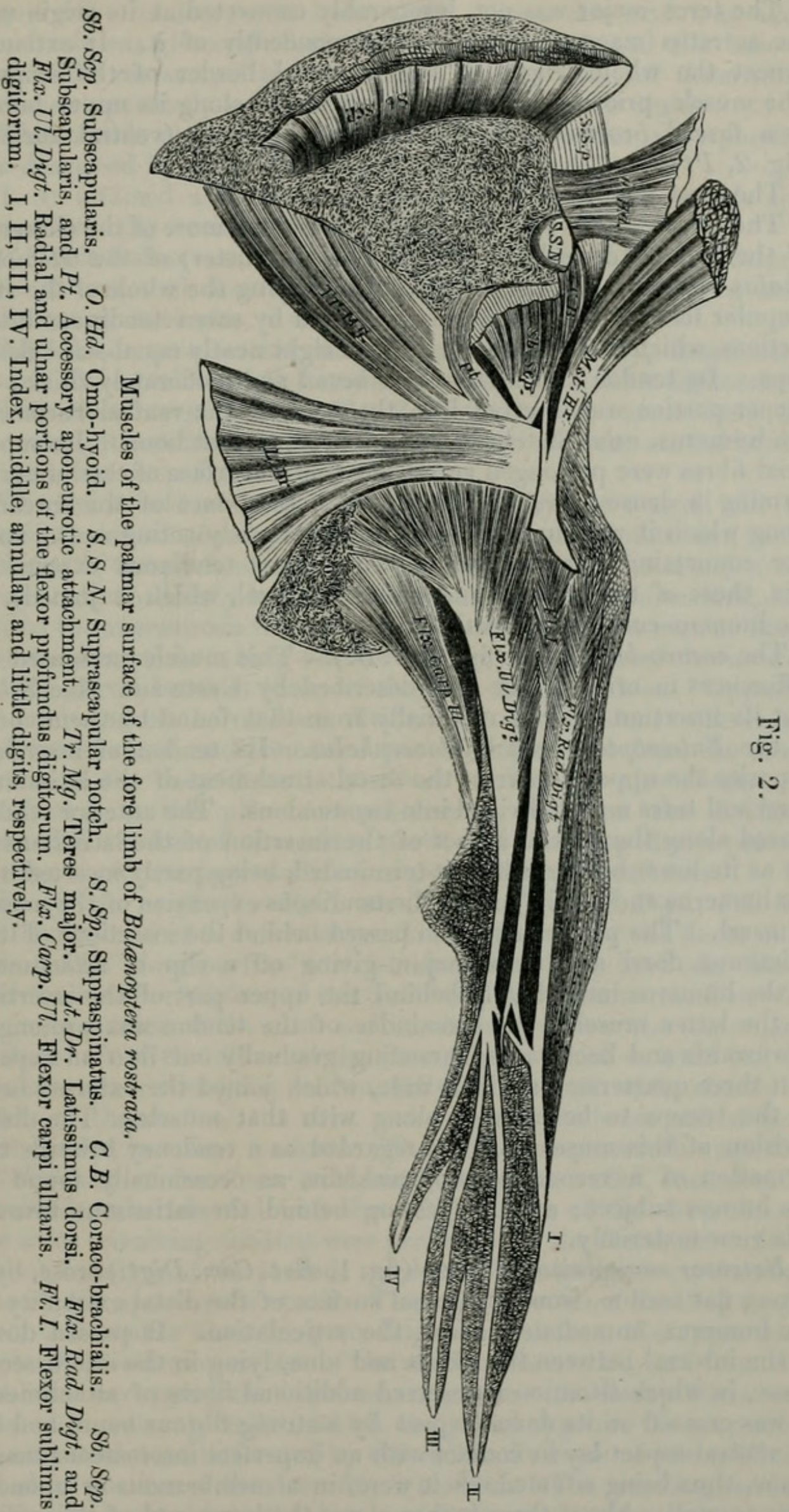


The teres major was not inseparably connected at its origin with the serratus magnus, but arose independently of it. It extended almost the whole length of the postaxial border of the scapula. The muscle, prior to its insertion, was joined along its upper border by a fascial process from the capsular ligament (ventral surface) (fig. 2, Pt).

The teres minor was absent.

The subscapularis (fig. 2, Sb.Scp.) presented more of the character of the muscle (described by Carte and Macalister) of the Globiocephalus svineval. It was very large, occupying the whole of the subscapular fossa. Its surface was traversed by seven tendinous intersections, which divided the muscle into eight nearly equal-sized fleshy slips. Its tendon of insertion was broad and moderately thick; its deeper portion was inserted into the neck of the ventral surface of the humerus, immediately below the head of that bone. Its superficial fibres were prolonged across the ventral surface of the humerus, forming a dense investment to it, on to the bones of the forearm, along which it was further continued, previously acting as the anterior connecting ligament, along with other tendinous expansions (viz. those of the pectoral and masto-humeral, which it joined), to the humero-cubital articulation.

The coraco-brachialis (fig. 2, C. B.).--This muscle presented no differences in origin from that described by Carte and Macalister. But its insertion differed materially from that found by them, both in the Balanoptera and Globiocephalus. Its tendon of insertion, opposite the upper border of the distal attachment of the latissimus dorsi and teres major, divided into two tendons. The anterior tendon passed along the ventral aspect of the insertion of the latissimus as far as its lower border, where it terminated, being partly inserted into the humerus and partly joining the tendinous expansion of the mastohumeral. The posterior tendon passed behind the insertions of the latissimus dorsi and teres major, giving off a slip of attachment to the humerus immediately behind the upper part of the insertion of the latter muscle; the remainder of the tendon was prolonged downwards and backwards, spreading gradually out into an expansion three quarters of an inch wide, which joined the external head of the triceps to be inserted along with that muscle. The distal division of this muscle may be regarded as a tendency towards the formation of a second coraco-brachialis, as occasionally found in the human subject; and its passing behind the latissimus favours this view materially.

Extensor communis digitorum (fig. 1, Ext. Com. Digt.) arose, by a strong flat tendon, from the dorsal surface of the distal extremity of the humerus, immediately above the articulation. It passed down in the interval between the radius and ulna, lying in the interosseous space, in which situation it received additional fibres of attachment. It was crossed on its dorsal aspect by a strong fibrous band, and by its ventral aspect lay in contact with an imperfect interosseous membrane, thus being situated, as it were, in a membranous or aponeurotic tunnel. About three inches above the lower end of the radius 
it gave off a tendon to the index digit. From this tendon an additional one was given off to the dorsal carpal fascia and the base of the middle metacarpal bone. Besides these it gave off three other tendons respectively to the second, third, and fourth digits.

This muscle presented a few differences from the corresponding one described by Carte and Macalister, namely :-

1. It attained a humeral attachment, whereas Macalister's specimen had only a radio-ulnar attachment.

2. Its indicator tendon gave off an additional slip to the metacarpus.

3. It was well developed, Macalister's specimen being a mere rudimentary fasciculus.

The flexor muscles are three in number-namely, flexor carpi ulnaris, flexor sublimis digitorum, and flexor profundus digitorum.

The flexor carpi ulnaris (fig. 2, Flx. Carp. Ul.) arose from the olecranon, its ventral aspect, and was inserted into the ventral border of the lower end of the ulna.

The flexor sublimis digitorum (fig. 2, Fl. I.) was a small and bipenniform muscle, occupying the interval between the ulnar and radial divisions of the profundus flexor. It arose from the distal end of the humerus, immediately below the insertion of the latissimus dorsi, and behind the aponeurosis from the masto-humeral. Its muscular fibres soon terminated in a long slender tendon, which passed downwards in the interval between those of the deep flexor tendons. Opposite the lower end of the radius it divided into two tendons: the radial tendon was short, and joined a corresponding tendon from the ulnar portion of the deep flexor; the ulnar tendon was also short, and terminated in the palmar carpal fascia. Between the divisions the radial tendon of the ulnar portion of the deep flexor passed, forming a rudimentary condition of perforatus and perforans.

The flexor profundus digitorum (fig. 2, Flx. Rad. Digt., Flx.Ul. Digt.) consisted of two distinct portions, separated by the flexor sublimis. The ulnar portion was fan-shaped, arising by fleshy fibres from the anterior surface of the distal end of the humerus, from the adjoining surface of the ulna and its olecranon, from the upper part of the shaft of the ulna and the strong fascia which covered it. It terminates in a strong flat tendon, fully half an inch wide, about the middle of the shaft of the ulna, and opposite the lower end of that bone divided into four tendons. The radial one passed through the two divisions of the flexor sublimis, joining the radial one, already described, to be inserted into the radial tendon of the deep flexor. The three remaining tendons were prolonged to the distal extremities of the phalanges of the second, third, and fourth digits respectively, imbedded in aponeurotic canals. The radial portion of the deep flexor was much smaller than the preceding: it arose from the upper twothirds of the anterior surface of the shaft of the radius, and from the membrane occupying the interosseous groove. Its fleshy fibres terminated in a strong tendon, which was joined opposite the carpus by the conjoined tendon formed by the radial divisions of the sublimis and ulnar portion of the deep flexor tendons. The resulting tendon was finally inserted into the distal extremity of the first digit. 
This arrangement differs somewhat from that described by Carte and Macalister.

There was no palmaris longus.

The suprascapular ligament is triangular in shape, $2 \frac{1}{2}$ inches long, and attached by its base to the upper border of the scapula, reaching as far outwards as the coracoid process. The omo-hyoid muscle is attached to the whole length of this ligament.

The suprascapular notch was oval in shape, the long axis of the ellipse running parallel with the supraspinatus muscle, measuring 2 inches; its vertical axis measured $1 \frac{1}{2}$ inch. It transmitted the large suprascapular nerve, and was closed in posteriorly by the supraspinatus muscle.

The Scapulo-humeral Articulation.-This articulation is a perfect enarthrosis, provided with a complete capsular ligament, stronger on the ventral than the dorsal aspect of the joint. It is not perforated by the tendon of the subscapularis muscle, as described by Carte and Macalister in their specimen. Although the tendon of the subscapularis lies in close contact with it, it could be readily detached by careful dissection, without any appearance whatever of perforation.

The capsular ligament was strengthened on its dorsal aspect by a strong ligamentous band, which was attached proximally by a broad expansion to the margin of the glenoid and the adjoining surface of the base of the coracoid; from this wide attachment the ligament rapidly narrowed to a strong and thicker band, about one quarter of an inch wide, which passed across the capsular ligament to be inserted into the humerus immediately to the ulnar side of the infraspinatus tendon, and behind the tendon of insertion of the deltoid. This articulation has a large and somewhat loose synovial membrane, which could be readily demonstrated by dissection.

From the ventral aspect of the capsular ligament a strong tendinous process, about an inch and a quarter wide, arose, passing behind the subscapular muscle, and joined the upper fibres of insertion of the teres major muscle (fig. 2, Pt). No distinct muscular fibres could be detected in this fascial process, though it is evidently homologous to a peculiar muscle which is occasionally found in the human subject.

The humero-cubital articulation is formed by the direct apposition of the slightly convex and transversely flattened distal extremity of the humerus with the flattened and but slightly concave proximal ends of the radius and ulna, the latter bone having on its postaxial border its cartilaginous olecranon prolonged backwards on to the humerus somewhat beyond the remainder of the bone. There was but very slight movement in this articulation, the greatest extent being allowed at the point of the recurvation of the olecranon, and the direction of the movement from before backwards. There is a distinct synovial membrane, though extremely thin, but capable of demonstration, especially at the postaxial side of the joint, where the greatest movement was found. There seem to be no distinct and separate ligaments, the place of the latter being supplied by the 


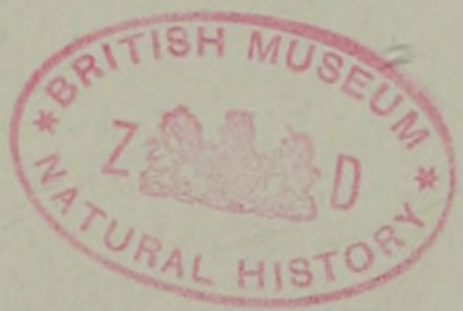


P Z.S. 1870.P1. XL1X.

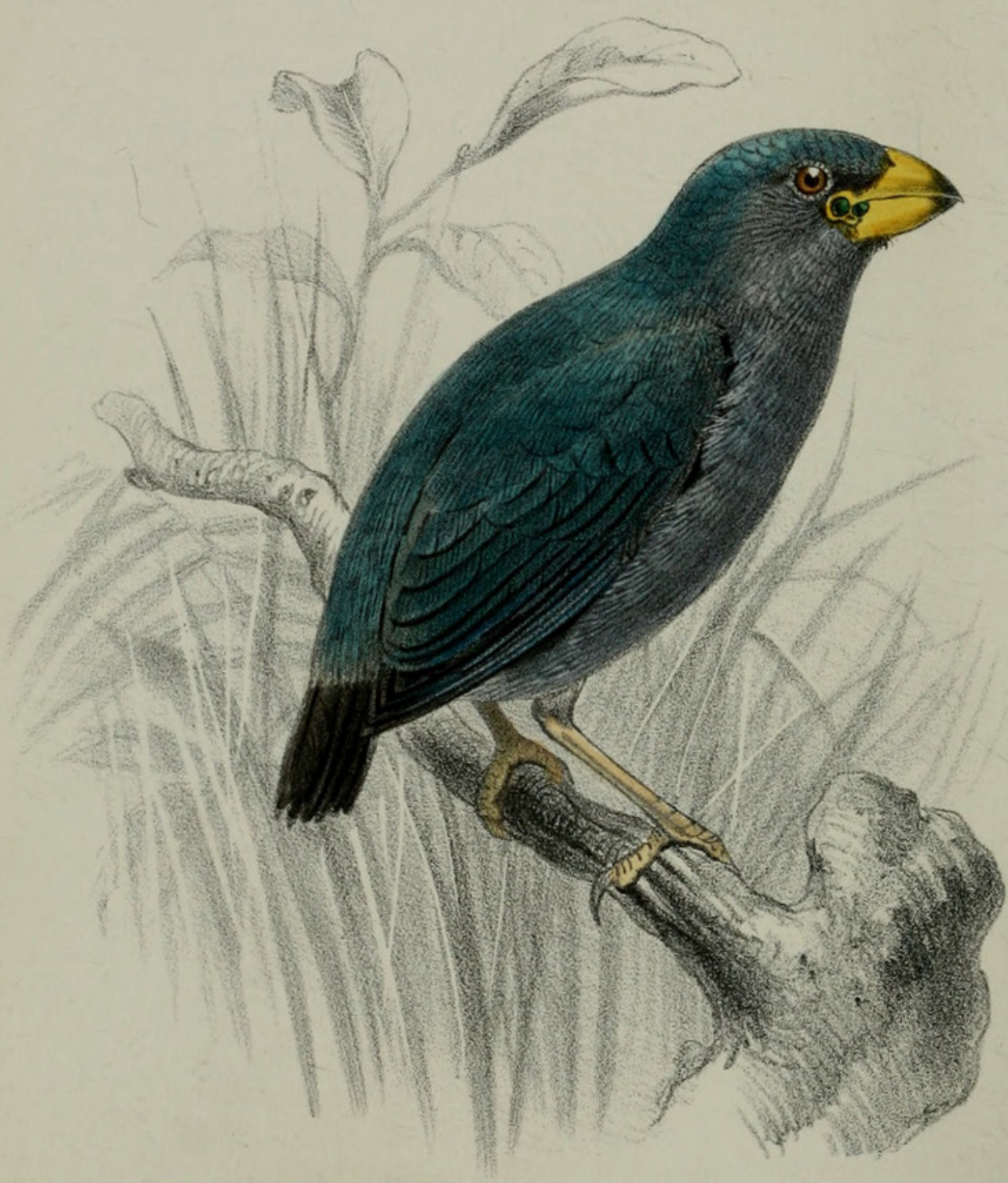

$J$ Sinit hith .

M \& N. Hanhart imp 
fibrous expansions from the humeral muscles, more especially the great pectoral, masto-humeral, the subscapularis, the infraspinatns, and deltoid.

2. On Lobiospiza notabilis, a remarkable new Finch from the Navigator's Islands. By Dr. G. Hartlaub, F.M.Z.S., and Dr. O. Frnsch, C.M.Z.S.

\section{(Plate XLIX.)}

In a collection of birds sent for determination from the private museum of Messrs. Johann and Cesar Godefroy of Hamburg, we received a little Finch, which proves to be new to science. The single specimen was collected by the well-known explorer of the Central Pacific Islands, Dr. Eduard Gräffe, in the island of Upolu.

We congratulate the indefatigable traveller upon this discovery, it being the more important and interesting inasmuch as, until now, among the extensive series of Fringilline birds no member has been found having the gape ornamented with wattles. The "Wattled Finch," therefore, merits, in our opinion, to rank as the type of a new genus, which we propose to call

Lовiospiza, gen. nov.

Char. gen.-Rostrum robustum, integrum, rotundatum, basi dilatatoincrassatum, culmine rotundato ; naribus occultis ; rictu carunculato, caruncula rotundata, verrucis duabus obsita.

Ala longiuscula, remigibus tertio et quarto aquilongis; primo brevissimo $\left(3^{\prime \prime \prime}\right)$

Cauda brevior, mollis, attenuata; rectricibus augustatis, debilibus, apicibus subacuminatis.

Pedes majusculi, graciles; tarso caligato ; digito interno et externo aquilongis; unguibus acutis, compressis, valde arcuatis.

The most striking feature in this singular genus is, as already mentioned, the presence of wattles. These are composed by the margins of the angle of the mouth, which are swollen and prominent, forming a rounded leaf-like small caruncle, which is besides ornamented with two small prominent granule-like verrucæ. These caruncles resemble those of Heteralocha; but in the latter they are considerably further extended, and smooth. The remaining generic characters agree with those of the nearest ally, Amblyura, Reichb., except in having the bill proportionally stouter and more fornicated.

Lobiospiza notabilis, sp. nov. (Plate XLIX.)

Diagn.-Tota obscure et obsolete carulescens, plumis basin versus nigricantibus: subius pallidior; remigibus et rectricibus nigris, carulescente marginatis; cauda tectricibus superioribus fuscescentibus ; plumulis supranasalibus conspicue nigricantibus ; rostro Aavidn, apice nigricante; pedibus infuscatis. 
Uniform dull blue, in a certain light with a faint shadow of greenish blue; the base of the feathers blackish, giving a somewhat mottled appearance, especially on the head; lores blackish; underparts somewhat lighter blue than the back; the feathers on the vent with very indistinct whitish bars; remiges brownish black; primaries with narrow, secondaries with broad margins of dull blue along the outer webs; under wing-coverts pale isabelline; upper tail-coverts dirty brownish; tail-feathers blackish brown, narrowly margined externally with greyish brown.

Bill hornish yellow tipped with blackish; on the gape a naked oval caruncle, also yellow, with two blue verrucæ; legs and feet pale brownish.

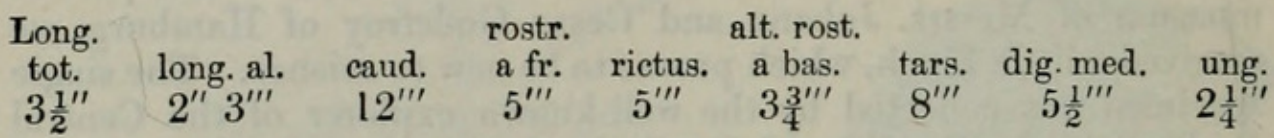

The unique specimen described above was preserved in spirits, and is evidently a young bird. The coloration of the old bird may very probably differ a good deal, as is the case between old and young specimens of both species of Amblyura. Analogously to the latter, it might be suspected that the dirty brownish tinge on the upper tail-coverts would change to red.

Unfortunately no notice is given of the habits, or the colours of the naked parts alive. The stomach contained small seeds and grains.

3. Notes on a Collection of Arachnida made by J. K. Lord, Esq., in the Peninsula of Sinai and on the African borders of the Red Sea. By the Rev. O. P. Cambridge, M.A., C.M.Z.S.

\section{(Plate L.)}

The above collection contained two species of Scorpionidea (upon the specific identity of which I am unable at present to offer any reliable opinion), two species of Solpugidea, and nineteen species of Araneidea. The Scorpions belong, I believe, to the genera Telegonus and Androctonus (Koch); the Solpugidea were the Solpuga araneoides (Oliv.) and the Solpuga melana (Savign.) (Rhax melana, Koch). Of the former there were several examples, captured in the Wady Ferran, peninsula of Sinai; it is an abundant species in Upper Egypt, as well as in the plains of the Jordan, lurking by day under the stones and among the débris of old ruins, and at night running abroad with great activity and swiftness: of the latter species (S. melana) there was but one example, captured also in the Wady Ferran; its dark colour and short legs serve to distinguish it readily from the former. Both are described and figured by Savigny in his great work (Egypte, Arachnides, pl. 8. figs. 7-9).

The following is a list of the Araneidea, which comprised three 


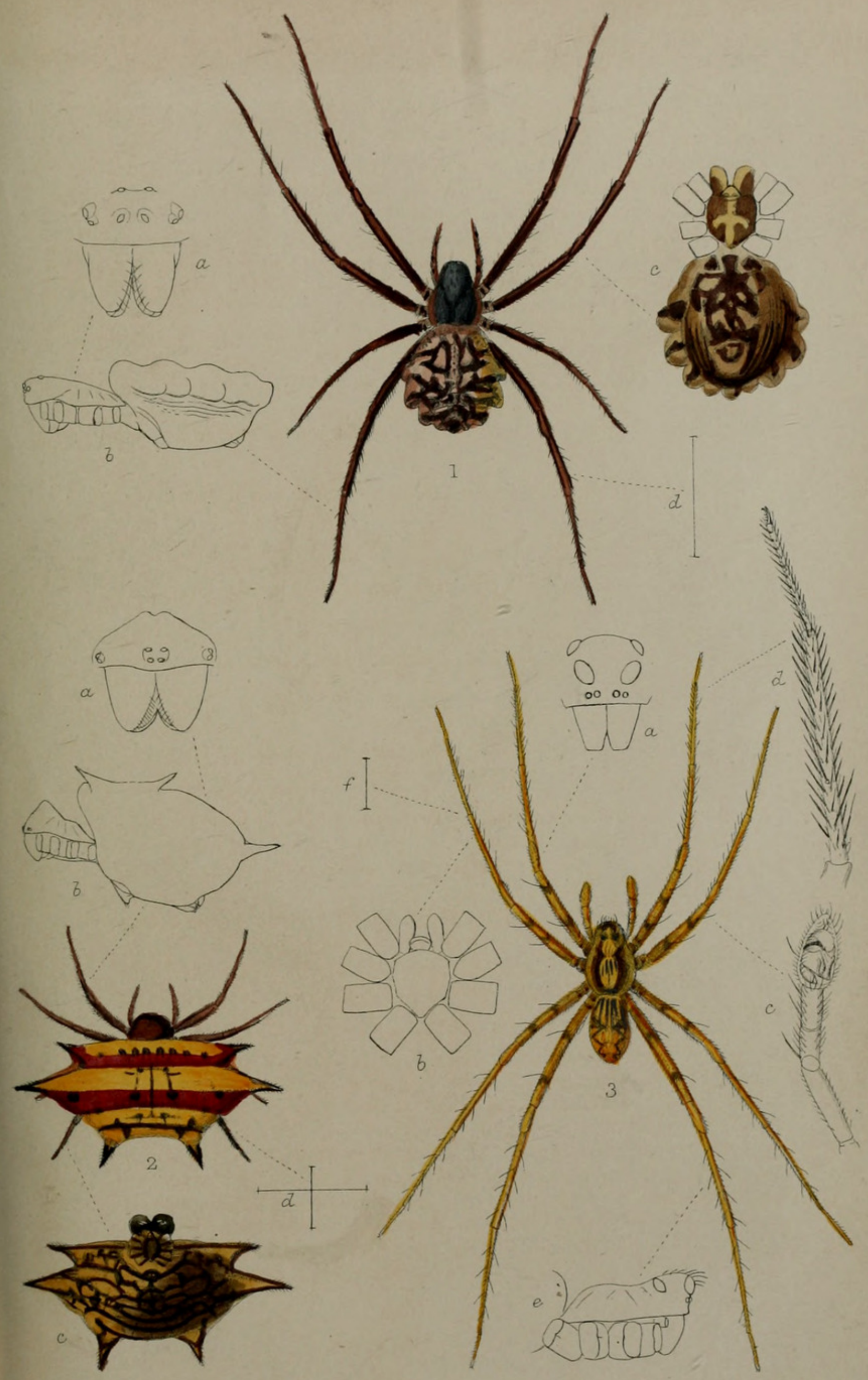



species apparently new to science, and of which descriptions and figures are added below.

1. Segestria perfida, Walck. Ins. Apt. i. 267.-Wady Gherandel, pen. Sin.

2. Drassus listeri, Savign. Egypte, Arachn. p. 155, pl. 5. fig. 4.Convent gardens and back of Mount Sinai.

3. Pholcus rivulatus, Savign. Egypte, Arachn. pl. 3. fig. 12.Convent gardens and back of Mount Sinai.

4. Latrodectus hamatus, Koch, Die Arachn. vi. tab. ccvi. figs. 507, 508.- Convent gardens and back of Mount Sinai.

5. Argiope aurelia, Savign. Egypte, Arachn. pl. 2. fig. 5.Inland from Massowah.

6. Argiope lordii, Cambr., n. sp.-Inland from Massowah.

7. Argiope sericea, Savign. Egypte, Arachn. pl. 2. fig. 6.Convent gardens and back of Mount Sinai.

8. Epeïra opuntice, Dufour; Walck. Ins. Apt. ii. p. 140.Inland from Massowah.

9. Epeïra solers, var.?, Walck. Ins. Apt. ii. p. 41.-Jebel Musa, pen. Sin.

I am not satisfied about the specific identity of this Spider; it is similar to several examples captured by myself in Egypt and in Palestine; and when the adult male is discovered, possibly it may prove to be undescribed; at present, only having seen the female (in which no structural difference is observable, though it differs somewhat in colours and integument), I include it as a variety of $\boldsymbol{E}$. solers.

10. Gasteracantha lepida, Cambr. n. sp.-Mangrove-swamps; African border of Red Sea.

11. Sparassus linnai, Savign. Egypte, Arachn. p. 160, pl. 6. fig. 2. - Hot springs, Pharaoh's Baths, Cairo.

Mr. Lord assures me that he captured this species (of which several examples were contained in his collection) in the water of the above baths, into which they voluntarily plunged. Independently of the high temperature ( $157^{\circ} \mathrm{Fahr}$.) of these waters making this a remarkable fact, it is the first species of this family of Araneidea (Thomisides) in regard to which, as far as my knowledge goes, aquatic habits have been observed.

12. Sphasus alexandrinus, Savign. Egypte, Arachn. p. 142, pl. 4. fig. 1.-Jebel Musa, pen. Sin.

13. Pasithea viridis, Blackw. Ann. \& Mag. Nat. Hist. 3rd ser. vol. i. no. 6, p. 427.-Jebel Musa, pen. Sin.

14. Lycosa pilipes, Lucas, Explor. en Algérie, Arachnides, p. 109, pl. 2. fig. 8.-Wady Gherandel, pen. Sin., Nasb, Genneh, Jebel Musa, and at Pharaoh's Baths, Cairo.

15. Lycosa prelongipes, Cambr., n. sp.-Wady Nasb, Genneh, Jebel Musa, pen. Sin. 
16. Lycosa tarentula apulia, Walck. Ins. Apt. tom. i. p. 281.In an old wall, Wady Ferran, pen. Sin.

17. Salticus vaillantii, Lucas, Explor. en Algérie, Arachnides, p. 136, pl. 5. fig. 2.-In an old wall, Wady Ferran, pen. Sin.

18. Attus sanguinolentus, Walck. Ins. Apt. tom. i. p. 473.Convent gardens and back of Mount Sinai.

19. Eresus acanthophilus, Duf.; Walck. Ins. Apt. tom. i. p. 399. -Wady Nasb, Genneh, Jebel Musa, and Convent gardens, back of Mount Sinai.

\section{Descriptions of new Species.}

\section{Genus Argiope (Savign.).}

\section{Argiope lordir, n. sp. (Plate L. fig. 1.)}

Female adult, length $8 \frac{1}{2}$ lines.

Cephalothorax flattened, oblong oval, strongly compressed laterally at the caput, which is rather produced; the normal furrows and indentations are well marked; the colour is deep brown, with a broad yellow thoracic margin, and reddish-yellow patches or suffusions at the junction of the caput and thorax ; the brown portions are thickly clothed with a short adpressed light grey pubescence, among which are some short erect dark bristles.

Eyes eight, not very unequal in size, in four pairs near the extreme upper fore margin of the caput; those of the two central pairs form an oblong figure, the eyes of the fore side being the largest of the eight, and slightly nearer together than those of the hinder side, though, owing to their larger size, they form a line of equal length; the eyes of each lateral pair are contiguous, placed obliquely on a small tubercle, and are more nearly in a straight line with the eyes of the fore than of the hind central pair.

Legs long and strong, of a deep red or chestnut-brown colour, with bands of short light grey hairs, furnished, not very thickly, with hairs, bristles, and small spines; each tarsus ends with three claws, the two superior ones strongly pectinated; and beneath them are some supernumerary opposed ones.

Palpi yellowish, clouded and striped with red-brown, furnished with hairs, coarse bristles, and fine spines; and each ends with a curved pectinated claw.

Falces moderately long, strong, vertical, conical ; of a deep brown colour, slightly tipped with yellow.

Maxilla short, strong, enlarged near their middle, round at the extremities; of a rich black-brown colour, broadly terminating at the upper extremities with yellow.

Labium short, broad, and subtriangular; it is of a black-brown colour at the base; and the apex, which is blunt in form, is yellow.

Sternum heart-shaped, slightly indented on its edges; it is of a deep brown colour charged with a large and somewhat cruciform yellow marking; and the whole is thinly clothed with fine grey hairs.

Abdomen large, of an oblong-oval form, flattened but irregular on 
its upper surface, and projecting over the base of the cephalothorax ; its fore margin is truncate ; the rest is considerably indented, forming strong lobes all round, especially towards the hinder part, which is somewhat transversely rugulose; its colour on the upperside is yellow, strongly marked with a complex zigzag or dentated pattern of a deep brown, which it is impossible to describe accurately and intelligibly, though easily seen in the figure. The yellow portions are more or less clothed with a silky white pubescence; the lateral lobes are yellow, and each is divided by a broad deep-brown band which runs over them from the upper- to the underside; the fore part of the abdomen is rather thickly furnished with short erect dark spiny bristles; the sides are yellow, striated with deep brown; and the underside is deep black-brown with yellow blotches and markings; the spiracular plates are of a reddish-brown colour, margined before and inside with yellow.

An adult female of this fine species, which $I$ believe to be undescribed, was captured by Mr. Lord inland from Massowah ; and I have great pleasure in naming it after its captor, by whose kindness I am able to describe and figure it.

N.B.-In describing the pattern on the abdomen of this (and other intricately marked) species, the dark colour might be taken as the ground-colour; but $\mathrm{I}$ have above assumed the lighter colour to be so.

\section{Genus Gasteracantha.}

\section{Gasteracantha Lepida, n. sp. (Plate L. fig. 2.)}

Female adult : length of abdomen 3 lines, breadth $5 \frac{1}{2}$ exclusive of the spines; length of the Spider $4 \frac{1}{2}$ lines, breadth to extremity of the lateral spines 8 lines.

The cephulothorax is similar in general form and appearance to that of many other allied species ; the caput is elevated, the occiput being the highest part, and its high transverse ridge is divided across the middle by a notch or groove into two quasi-segments; its colour is a deep rich chestnut-brown; the falces are rather deeper in colour, and the legs (which are moderately strong, not very long, and furnished with hairs and slender bristles) are of a rich deep brown colour; the palpi are similar in colour.

The maxilla, labium, and sternum are normal in structure and of a jet-black colour: the eyes also are normal in position; four form a small trapezoid, of which the fore side is the shortest, and are seated on a tubercle near the middle of the lower fore margin of the caput; and on either side is a lateral pair widely removed from the central square; the eyes of these lateral pairs are contiguous to each other, and each pair is seated on a strong lateral tubercular prominence of the fore corner of the caput.

The abdomen is of the usual horny texture; its breadth is double its length; and it is armed with six prominent sharp spines of different lengths, none being very long; two spring from the ends of the fore margin, and are directed a little forwards; behind each of these is another (the longest of the six) very slightly curved, and whose direction is in the least possible degree backwards: the 
remaining two issue from the hinder portion of the abdomen; they are about the length and strength of the two foremost, and are rather divergent from each other; all of them have a slight tendency upwards and are furnished rather thinly with bristly hairs: the fore margin, between the two foremost spines, is curved and indented in the middle; parallel with it is a row of the usual ten round impressed punctures, two others are behind each of the intermediate spines, a transverse row of five occupies the hinder margin, and four in a trapezoid, widest behind, occupy the centre; the upperside is of a bright rich orange-yellow, with two broad parallel transverse bands of blood-red tinged with carmine, connecting each of the fore pairs of spines in which they meet, the spines being strongly suffused with deep red-brown; one indistinct narrow transverse bar of cinnabar-red connects the hind marginal row of impressed spots ; and the bases of the two hinder spines, with a considerable portion of the immediately surrounding surface, are also of the same blood-red colour. The abdomen might almost be described as alternately barred, on the upperside, with transverse bars of red and yellow ; the underside is bright yellow, strongly striated and intersected with black, going off into red near the spines; the spinners are black; and between them and the epigyne is a conical, prominent, corneous-looking, shining prominence which is also of the same colour.

A single example of this species was captured in a geometric web in a mangrove-swamp, inland from Massowah; it is allied closely to Gasteracantha sanguinolenta (Koch), but may easily be distinguished by the greater proportional breadth of the abdomen and the greater length of the spines with which it is armed.

\section{Family Lycosides.}

\section{Genus Lycosa.}

\section{Lycosa PRælongipes, n. sp. (Plate L. fig. 3.)}

Male adult, length $3 \frac{1}{4}$ lines, length of a leg of the posterior pair nearly 12 lines.

This Spider is almost entirely of a brightish sandy-yellow colour ; the cephalothorax has two broad longitudinal lateral brown bands having a yellow lateral margin on each side, and a broad central one ; the last strongly constricted or indented near the middle at the junction of the caput and thorax, and enlarged at the middle of the thoracic portion, narrowing again at its posterior extremity; the region of the eyes is blackish, and the whole of the cephalothorax is thinly furnished with greyish hairs; the form of the cephalothorax is peculiar, the normal, lateral, oblique indentations which indicate the junction of the caput and thorax being very strong and forming a marked constriction, the thoracic portion being rounded (and, indeed, somewhat gibbous) in consequence, and leaving a dip or hollow between its highest point and the ocular region.

The four hinder eyes are unusually large, and form very nearly a square, the two foremost being the largest; the two centrals of the 
lower row are larger than the laterals, and each is further from the other than from the lateral on its side; the four form a curved line of less length than that formed by the two large eyes above them, from which they are separated by half a large eye's diameter, and from the lower margin of the clypeus by rather more than that space.

The legs are very long, moderately strong, and furnished with hairs, bristles, and long slender spines. Some of the legs were a good deal fractured; but their relative length appeared to be $4,3,1,2$; those of the fourth pair greatly exceeded the rest, which did not seem to vary much in their relative length; the femora were marked on the uppersides with stripes and irregular bands of brown.

The palpi are short and moderate in strength; they are similar in colour and armature to the legs; the cubital joint is shorter but a little stronger than the radial; the digital joint is not large, it is about equal in length to the radial and cubital together, and it is of a yellow-brown colour; the palpal organs are neither very prominent nor complex, they have a sharp projecting corneous prominence at their outer extremity.

The maxilla are not very long or strong; but they incline towards the labium, which is broad, somewhat quadrate, rather narrower at its apex than at its base; its colour is yellow-brown, the apex sandy yellow. The sternum is very short, heart-shaped, pointed behind, and hollow on its fore margin.

The abdomen is small and of an oval form; in the example described it was much shrunk and shrivelled; but it appeared to have an irregular dark yellow-brown longitudinal band on either side of the median line, leaving a broad central longitudinal strongly dentated yellow band terminating just above the spinners.

An adult male of this Spider was obtained by Mr. Lord in a wady near Jebel Musa, Sinai. The length of the hinder pair of legs, and the constricted form of the cephalothorax, constitute very strong specific characters in this apparently hitherto undescribed species of a now numerous genus.

\section{EXPLANATION OF PLATE L.}

Fig. 1. Argiope lordii, o, p. 820 .

a. Fore right view of cephalothorax and falces.

$b$. Profile, without legs.

$c$. Underside, without legs.

d. Natural length.

2. Gasteracantha lepida, o, p. 821.

a. Fore right view of cephalothorax and falces.

$b$. Profile, without legs.

c. Underside, without legs.

d. Natural size (length and breadth).

3. Lycosa prcelongipes, ठ, p. 822 .

a. Fore right view of cephalothorax and falces.

$b$. Underside of cephalothorax.

c. Palpus.

d. Tarsal and metatarsal joints of leg of first pair.

$e$. Profile of cephalothorax, without legs.

$f$. Natural length.

Proc. Zool. Soc.-1870, No. LV. 
4. On the Occurrence of Lates calcarifer in Australia.

$$
\text { By Dr. A. Günther, F.Z.S. }
$$

$\mathrm{Mr}$. Sclater has received several specimens of a Perch from Mr. E. P. Ramsay, C.M.Z.S., of Dobroyde, Sydney, N.S.W. They were obtained from salt water at the mouth of the Fitzroy River, Queensland. At the first glance, I believed them to be the Australian Psammoperca waigiensis; but on a closer inspection I found that they had the lower limb of the præoperculum armed with four strong spines, and that they were of a species of Lates not distinguishable from the Indian Lates calcarifer. This species is known to inhabit fresh and brackish waters, and probably also enters the sea. The British Museum possesses a series of examples, with perfectly reliable information as regards the localities where they were obtained:- one example from the coast of North-western India (Playfair), several from the Ganges (Hamilton-Buchanan \&c.), one from Amoy (Swinhoe), several from China (Reeves), one from North China (Jamrach). Bleeker records specimens in his collection from Java, Madura, Banka, Borneo, and Celebes. The second Australian species of Lates (apparently limited to this continent) is Lates colonorum.

The pseudobranchiæ of Lates calcarifer are an extremely narrow strip of very short laminæ, and easily overlooked.

5. Description of an Adult Skull of Eupleres goudoti. By Dr. J. E. Gray, F.R.S. \&c.

\section{(Plate LI.)}

Flacourt, in his book on Madagascar, describes an animal under the name of Falanouc, which Doyère thinks he has identified with a young animal from Madagascar, sent to the Jardin des Plantes by M. Goudot. He described it under the name of Eupleres goudotii; but Schlegel, in the Ned. Tydschr. Dierk. vol. i. p. 292, in his list of Madagascar mammalia, obserres it is not at all proved that the $\mathbf{F a}$ lanouc of Flacourt (p. 154) is the Eupleres goudotii of naturalists.

Eupleres goudotii is described by M. Doyère, in the Ann. des Sc. Naturelles, 1835, vol. iv. p. 281 , tab. xviii., from a very young animal preserved in spirits, and its skull. He describes the fur as very dark brown, with a fulvous under-fur, and two black streaks across the shoulders. The same skull is figured in Blainville's 'Ostéographie' as Viverra goudotii, tab. viii., and also the bones of the feet and other parts of the same.

I am not aware that the adult animal of this species has been observed. MM. Pollen and Van Dam do not appear to have observed it; at least it is not so stated in M. Schlegel's list of their animals, nor is it figured in their work.

The British Museum has lately received a large cat-like animal, 


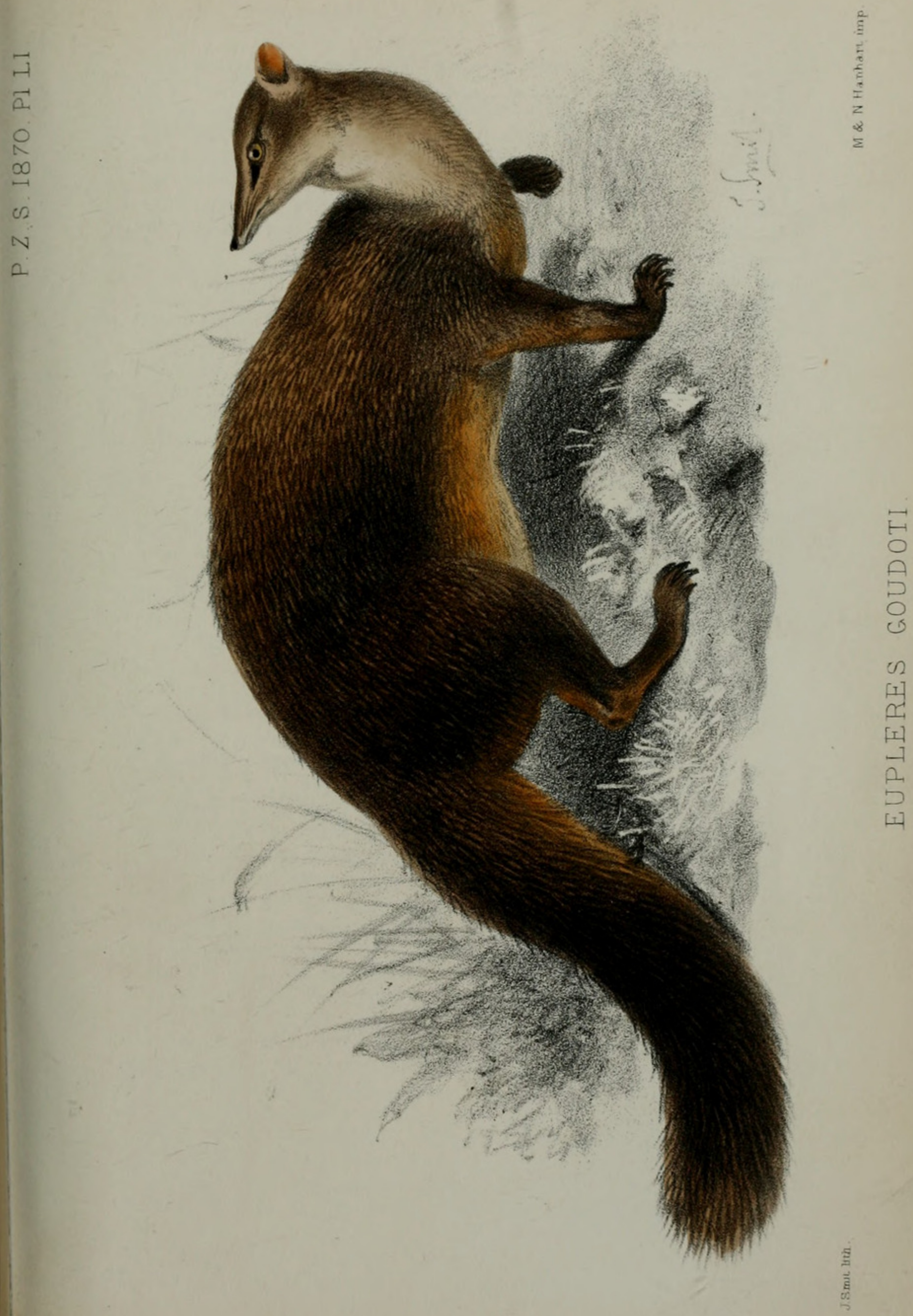



with a veŕy small head and extremely slender and long nose and a long cylindrical and bushy tail, from Madagascar, under the name of Falanaka, which I was inclined to think might be the adult state of the Eupleres goudotii of M. Doyère. But it has no appearance of the black bands across the shoulders which he describes and figures, and therefore I doubted the identity. But the examination of the skull has entirely set all doubts at rest, for it is certainly the adult state of the skull figured by M. Doyère with its milk-teeth; and therefore I suspect that the existence of the black bands mentioned in his description and shown in the figure may be caused by the manner in which the hairs clustered together when the animal was taken out of spirit and put in position, as they sometimes will do ; or it may be that the young animal may be so marked; but I do not think that this is likely.

As the genus has only been described from a young specimen, I send a description of the adult skull and teeth.

\section{Eupleres, Doyère.}

Skull very elongate, narrow, nearly three times as long as broad; the brain-case ovate; zygomatic arch long and very slender; orbit large, oblong, very imperfect behind, quite open to the temporal cavity, without any processes either above or below; nose very slender, as long as the breadth of the broadest part of the braincavity; nasal bones very slender, elongate; maxillary bones high ; interorbital foramen large, inferior; the nose divided in the middle about one third of its length; palate narrow, rather wider behind, rather concave in the middle of its length, truncated behind, the opening of the internal nostril, some distance behind the last grinder, elongated, with nearly parallel sides.

Lower jaw very slender, light, with a long produced subcylindrical angle behind, narrow and rather flattened in front, with a rather elongated symphysis. Cutting-teeth $\frac{6}{6}$; the upper small, truncated, forming a close arched series, the outer on each side being rather the largest; the lower smaller, forming a much smaller arched series, the outer on each side being the largest.

Canines $\frac{1}{1} \cdot \frac{1}{1}$; the upper small, conical, and much compressed and recurved, not quite so large as the first false grinder, and placed at a small distance from the outer cutting-tooth; the lower very small, close to and of the same form and size as the outer cutting-tooth.

Grinders $\frac{6}{6} \cdot \frac{6}{6}$; the upper false grinders three on each side, compressed and very far apart; the first very like and a very slight distance from the canine, and, like it, recurved; the second separated by an equally broad space from the first; and the third is compressed, with a recurved tip and an acute compressed lobe on the hinder edge; the third close to the flesh-tooth, forming with the other three hinder grinders a connected series like the preceding, but wider, with a very obscure process on the front edge, a broad compressed one on the hind edge, and a central conical recurved process. The flesh-tooth like the preceding, but with a subtriangular crown 
produced by a subanterior lobe on the inner side, and a more distinct lobe on the front edge, and a larger one on the hinder edge.

The first tubercles triangular, nearly equilateral, with three blank tubercles on the outer side of the crown, and a larger tubercle on the anterior internal process. The second tubercular grinder smaller, triangular, rather wider than long, with concave arched sides.

The three lower false grinders separated from each other by equal spaces like the upper ones; the first conical, compressed, some distance from and twice the size of the lower canine, which it resembles in shape; the second larger, compressed, with a very slight lobe on the front and a more distinct lobe on the hinder edge, and a high central cone; the third somewhat like the second but larger, with a more distinct anterior and a large posterior lobe. The lower carnivorous tooth oblong, with three anterior lobes placed in a triangle, and a large posterior one; the tubercular grinder similar to the preceding, but much larger and with larger anterior lobes, having a small lobe in the centre between the other three, and a very large hinder portion with a tubercle on the hinder margin.

Head elongate; nose very much produced, elongate, conical, acute, rounded beneath, with a very narrow central groove; whiskers slender, moderately long; muzzle bald, cartilaginous; nostrils open on the side; lower jaw narrow in front; ears rounded, hairy on the outside. Body elongate, rather slender, closely covered with hair ; legs moderate, of equal length. Soles of the feet with 6 pads, one central ; toes 5.5 , buried in the skin to the claws; the front toes 4 , with elongated arched compressed claws, the inner toe shorter; claws of the hind feet short, of the inner toe abortive; the hinder side of the tarsus hairy; the tail rather shorter than the body, cylindrical, truncate, covered with abundance of hair, which is rather longer than that on the back.

I believe the adult animal and its skull show that I placed the genus in its correct position in the 'Proceedings' of the Society in 1864, and in the 'Catalogue of Carnivorous Mammalia in the British Museum,' when I arranged it near Crossarchus, in the family Rhinogalida. M. Doyère considered it an insectivorous animal, regarding the front double-rooted tooth in the lower jaw as a canine; but Blainville properly regarded it as more allied to the Viverrida. And this decision is proved by the examination of Blainville's figure of the young skull, tab. xii., and the examination of our older skull, both of which show that the small tooth in the upper jaw, which I have called the canine, is placed just behind the suture, between the maxillary and intermaxillary bones, which is the normal situation of the canine.

It differs from the other genera of the family in the smallness of the head, the great slenderness of the nose, and in the small size of the canine teeth; and for this reason I think it ought to form a separate tribe of the family Rhinogalida, which would be called Euplerina.

The head of the animal, and also the skull, becomes longer and more slender in comparison with its breadth as it arrives at the adult age; and the great distance of the false grinders from each 
other and the similarity of the first to the canine, as well as their recurved tips, are peculiar to this genus.

Fig. 1.

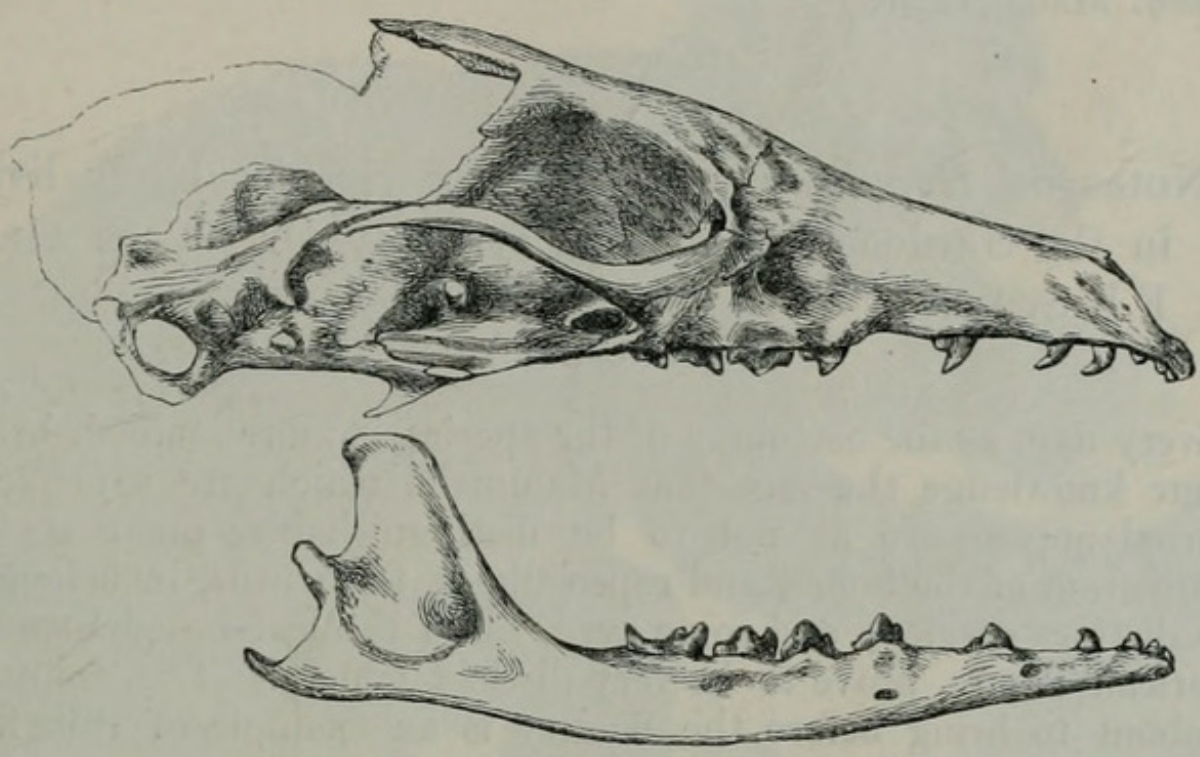

Skull of Eupleres goudoti.

Fig. 2.

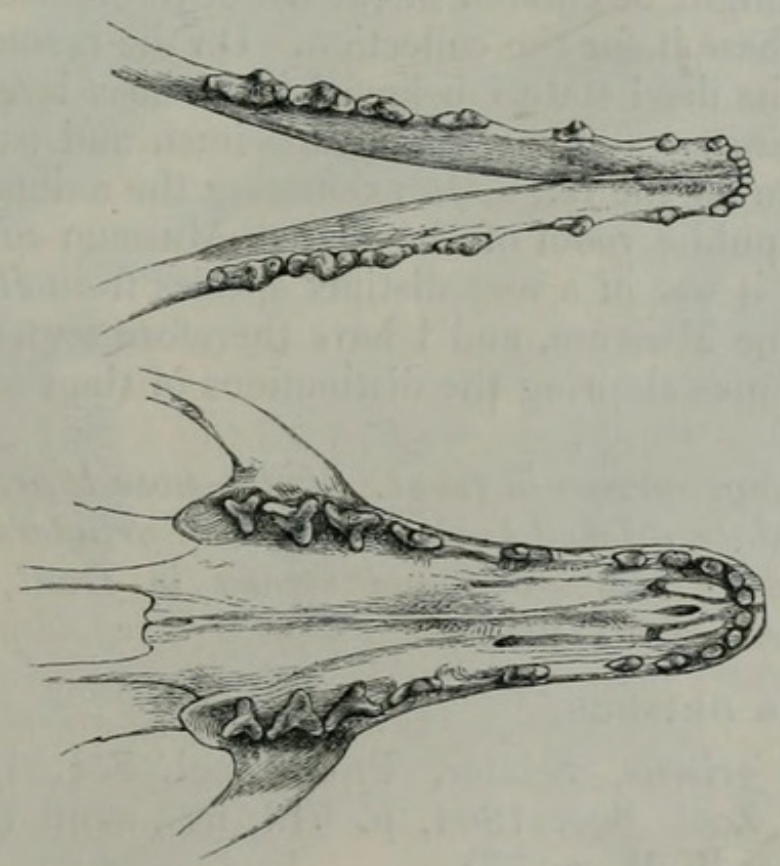

Upper and lower jaws of Eupleres goudoti.

Eupleres goudoti. (Plate LI.)

B.M.

Fur olive, minutely punctulated with yellow; cheeks, temples, chin, throat, belly, inside of limbs, brownish white; underside of the base of the tail paler than the upperside.

Eupleres goudotii, Doyère, Ann. Sci. Nat. 1835, iv. p. 281, t. 18 (animal and skull); Gray Proc. Zool. Soc. 1864, p. 578; Cat. of 
Carnivorous Mamm. Brit. Mus. p. 177; De Blainville, Ostéogr. Viverra, tab. viii. (skull), xi., xii. (other bones).

Falanaka, Gray, Ann. \& Mag, Nat. Hist. 1870, vol. vi. p. 424.

Length of body and head 22 inches, tail $10 \frac{1}{2}$ inches, $=32 \frac{1}{2}$ inches. Hab. Madagascar.

6. Notes on Hapalemur simus, a new Species lately living in the Gardens of the Society. By Dr. J. E. GraY, F.R.S. \&c.

\section{(Plate LII.)}

Every day, as the osteology of the species is more studied, brings to our knowledge the fact that Mammalia which are so alike in external appearance as not to be distinguishable, prove on the examination of the bones, and especially of the skulls, to belong to very distinct species; and some even, as in the leaf-nosed Bats and American Tapirs, prove to be very distinct genera. The animal I am about to bring before the Society is an example of this kind among the Lemurida.

Mr. Bartlett during the autumn brought to the British Museum a Lemur which had died in the Society's Gardens to be determined, that its name might be entered in the list of recent accessions; and I agreed to purchase it for the collection. On the casual inspection of the animal in its dead state I believed it to be a large specimen of Hapalemur griseus. The preserved specimen and skull were exhibited on November the 1st. On examining the animal before it was placed in the public room of the British-Museum collection, I was convinced that it was of a very distinct species from Hapalemur griseus, then in the Museum, and I have therefore sent to the Society the following notes showing the distinctions of the two species.

I. Nose tapering, narrow in front. Skull-nose tapering, narrow in front; palate dilated behind; series of grinders converging in front; lower jaw broad and strong in front, with a long symphysis. HAPALEMUR.

Hapalemur griseus.

B.M.

Hapalemur grisens, Sclater, Proc. Zool. Soc. 1863, p. 181; Mivart, Proc. Zool. Soc. 1864, p. 613, fig., skull (copied, Catal. Monkeys \&c. in B. M. p. 77).

II. Nose broad and truncated. Skull-nose very broad, square, truncated in front; palate scarcely wider benind; series of grinders wide apart and nearly parallel; lower jaw weak and narrow in front, with a short symphysis. Prolemur.

Hapalemur simus, sp. nov. (Plate LiI.) B.M.

Back iron-grey, with a rufous tinge; the hairs black, with a sub- 


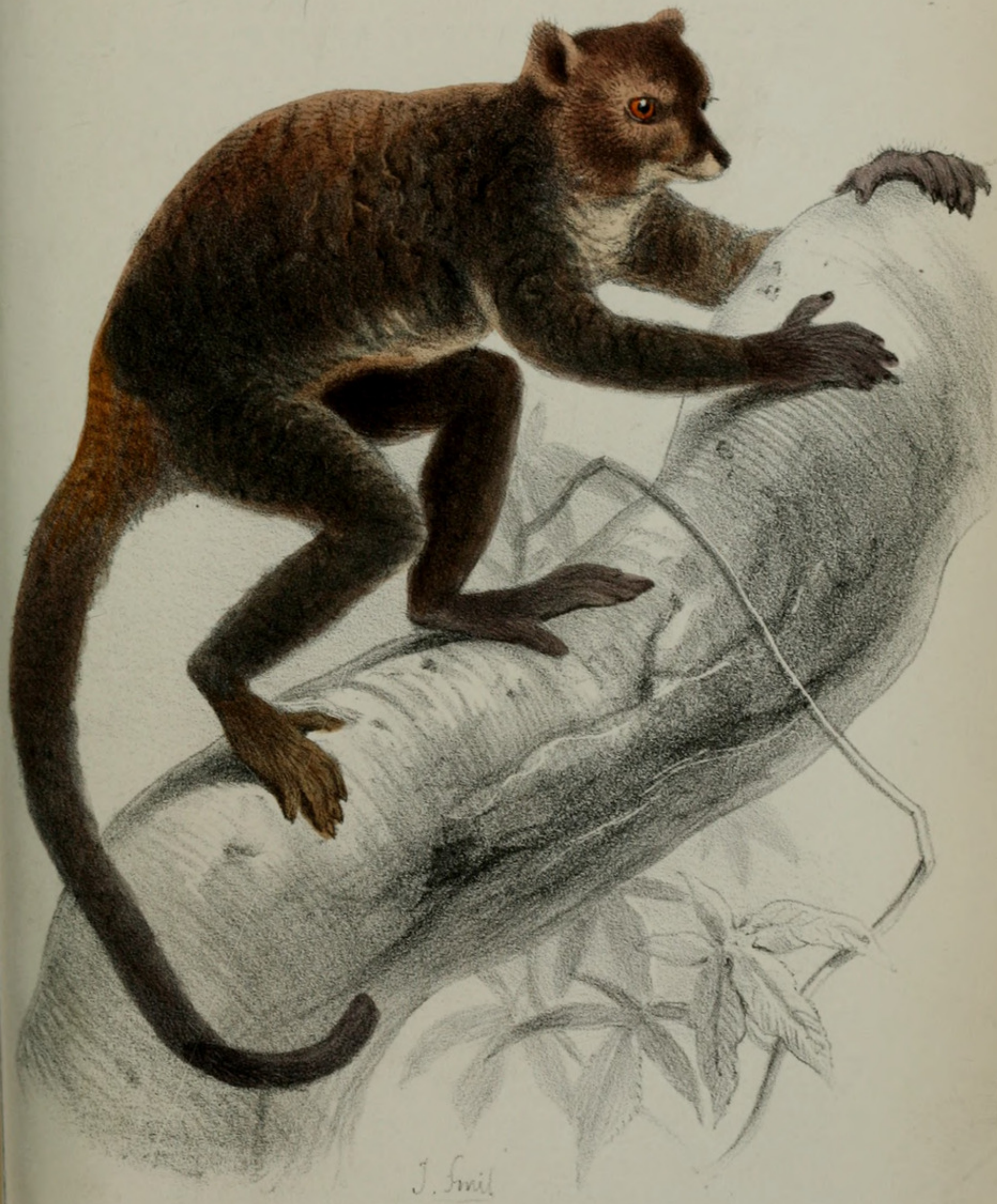




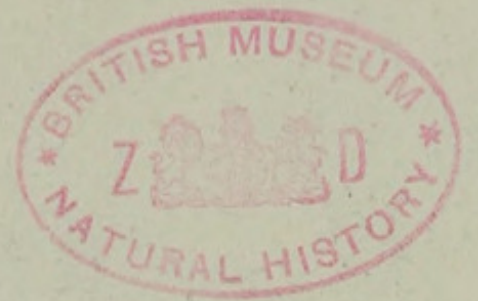


apical rufous band, and the lower part lead-coloured ; throat whitish ; spot on rump at base of tail yellowish.

\section{Hab. Madagascar.}

This may be Hapalemur olivaceus; but that species is very imperfectly described, and it is said to have a different form of the hinder part of the lower jaw; but what the difference is, is not mentioned, and I do not see any difference in the hinder part of the lower jaws of the two species. The front of the jaw in H. griseus is very much more slender and weak than in $H$. simus.

Fig. 1.

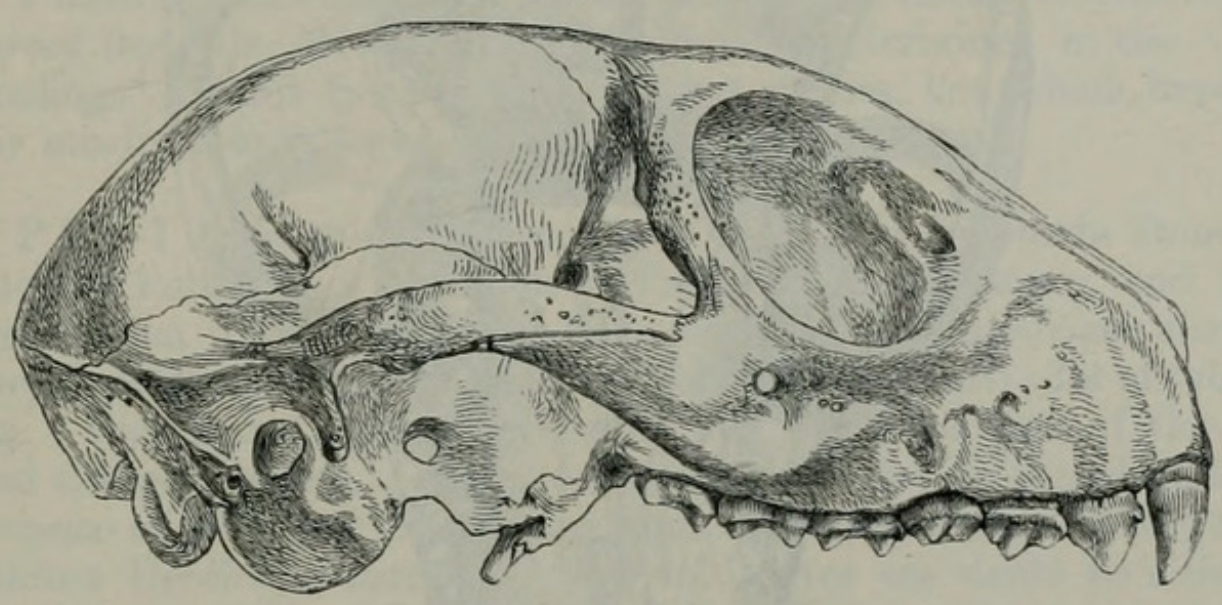

Hapalemur simus.

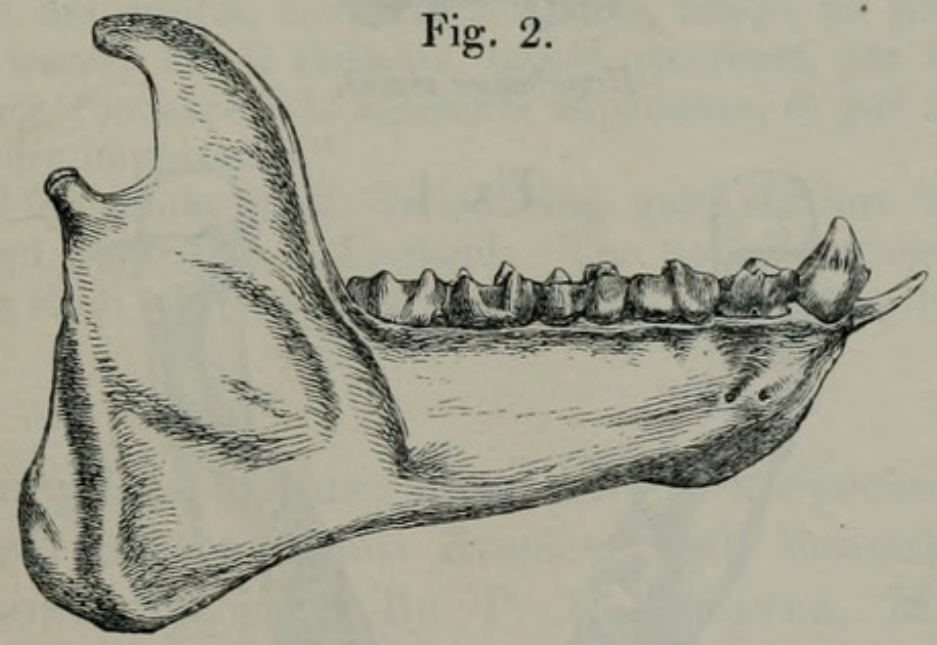

Hapalemur simus.

The skull rather solid; nose broad, truncated in front; palate slightly concave, nearly as broad before as behind, the teeth-series being nearly parallel : cutting-teeth $\frac{4}{6}$; the upper subcylindrical, close by the front side of the canine; inner rather the smallest; lower shelving, in two groups, the four inner much compressed: canines $\frac{1}{1} \cdot \frac{1}{1}$; upper triangular, conical; lower rather compressed, with a conical lobe on the front edge.

The animal on which this species is established is full-grown; but 
Fig. 3 .

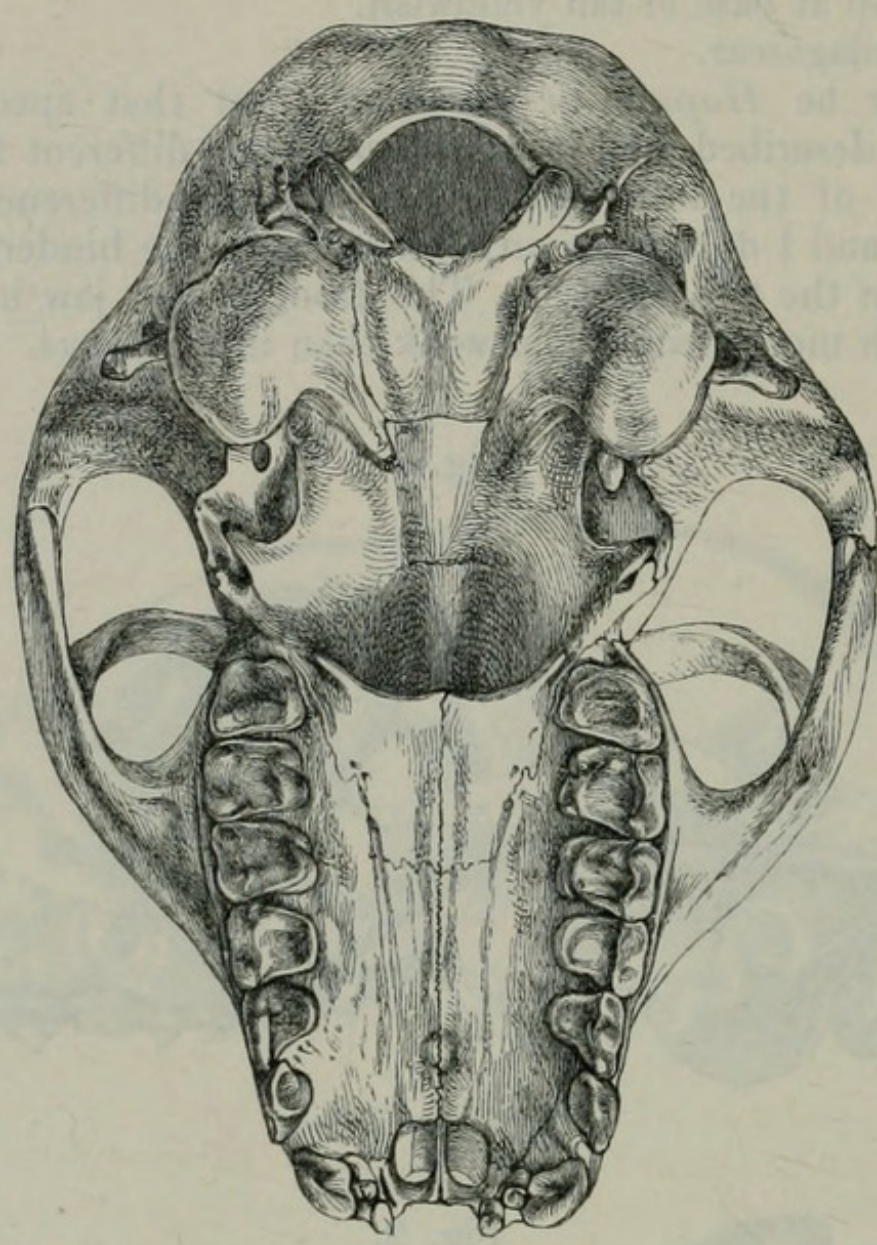

Hapalemur simus.

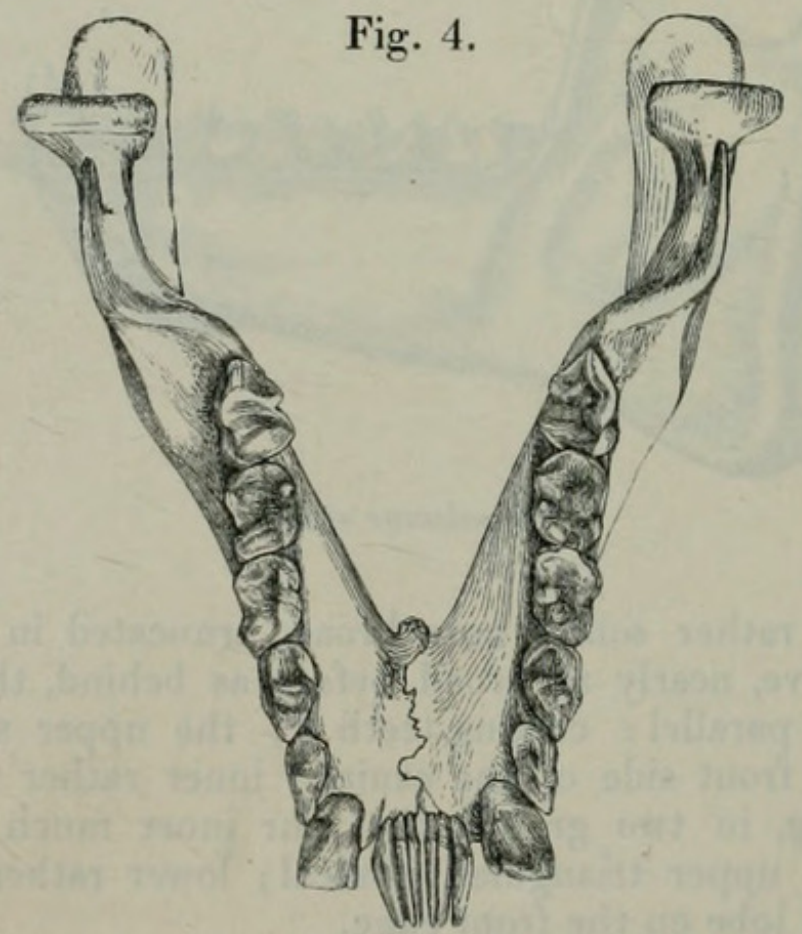

Hapalemur simus. 
the state of the hinder grinders shows that it had not reached adult age ; it shows no sign of sexual organs, but is most probably a female.

It died soon after its arrival at the Gardens, and unfortunately had not had time to recover the effects of its confinement on the voyage.

The tips of the long hairs of the fur of the greater part of the body have been worn off, leaving only a lead-coloured cottony wool. The head, neck, and outside of limbs, where the tips of the long hairs remain, are exactly the same colour as the fur of the British-Museum specimen of Hapalemur griseus, not showing the slightest reason for believing that one would be called $H$. griseus and the other $H$. olivaceus.

I have retained the name of $H$. griseus for the specimens we received from Dr. Meller, which Mr. Sclater determined in the 'Proceedings' of this Society to be of that species, but which have the fur much more fit to be called olivaceous than grey.

P.S.-I have to-day (Dec. 9th) been able to obtain from the Society Pollen and Van Dam's 'Faune de Madagascar;' and I see clearly that the animal that I have described as Hapalemur simus is the Hapalemur griseus of those authors (p. 6, tab. iii.); for at tab. vii. fig. 4 they figure the skull, showing the truncated form of the nose and the wide palate. They consider it the same as the Hapalemur griseus of Geoffroy St.-Hilaire, and also Hapalemur olivaceus of Isidore Geoffroy, observing, "Le crâne arec ses dents ne s'éloigne en aucune manière de celui du soi-disant Lemur griseus; mais cette partie présente, suivant les individus, des différences très-sensibles par la forme des orbites, tantôt orbiculaires, tantôt un peu elliptiques, par les nasaux tantôt saillants, tantôt rentrants, par le manque ou l'existence d'incisive à la mâchoire supérieure, et par d'autre traits de moindre importance."

I had no doubt of $H$. simus being quite distinct from what we had called $H$. griseus in England. The upper cutting-teeth of the Museum skull of $H$. simus are as distinct as they are in $H$. griseus.

7. Descriptions of three apparently new Species of Tyrantbirds of the Genus Elainea, with Remarks on other known Species. By P. L. Sclater, M.A., Ph.D., F.R.S.

1. Elainea gigas, sp. nov. (Fig. 1, p. 832.)

Elainea albiceps, Scl. P. Z. S. 1860, p. 71, et Cat. A. B. p. 217 (nec Lafr. et D'Orb.).

Supra fuscescenti-olivacea, uropygio paulo dilutiore: pilei medii plumis ad basin late albis, fusco terminatis: alis caudaque fuscis, alarum tectricibus et secundariis albido marginatis: remigibus primariis et rectricibus olivaceo anguste fimbriatis : subtus pallide grisea, subalaribus, remigum marginibus internis 
et ventre medio cum crisso favido indutis: rostro pallide corneo, mandibula albicantiore, pedibus fuscis: long. tota $7 \cdot 5$, alce $3 \cdot 7$, cauda $3 \cdot 1$, tarsi $0 \cdot 8$, poll. Angl.

$H a b$. Respubl. Equator. in ripis fl. Napo.

Obs. Sp. crassitie majore et pilei plumis late albis ab $\boldsymbol{E}$. pagana, cui forma similis, distincta.

Fig. 1.
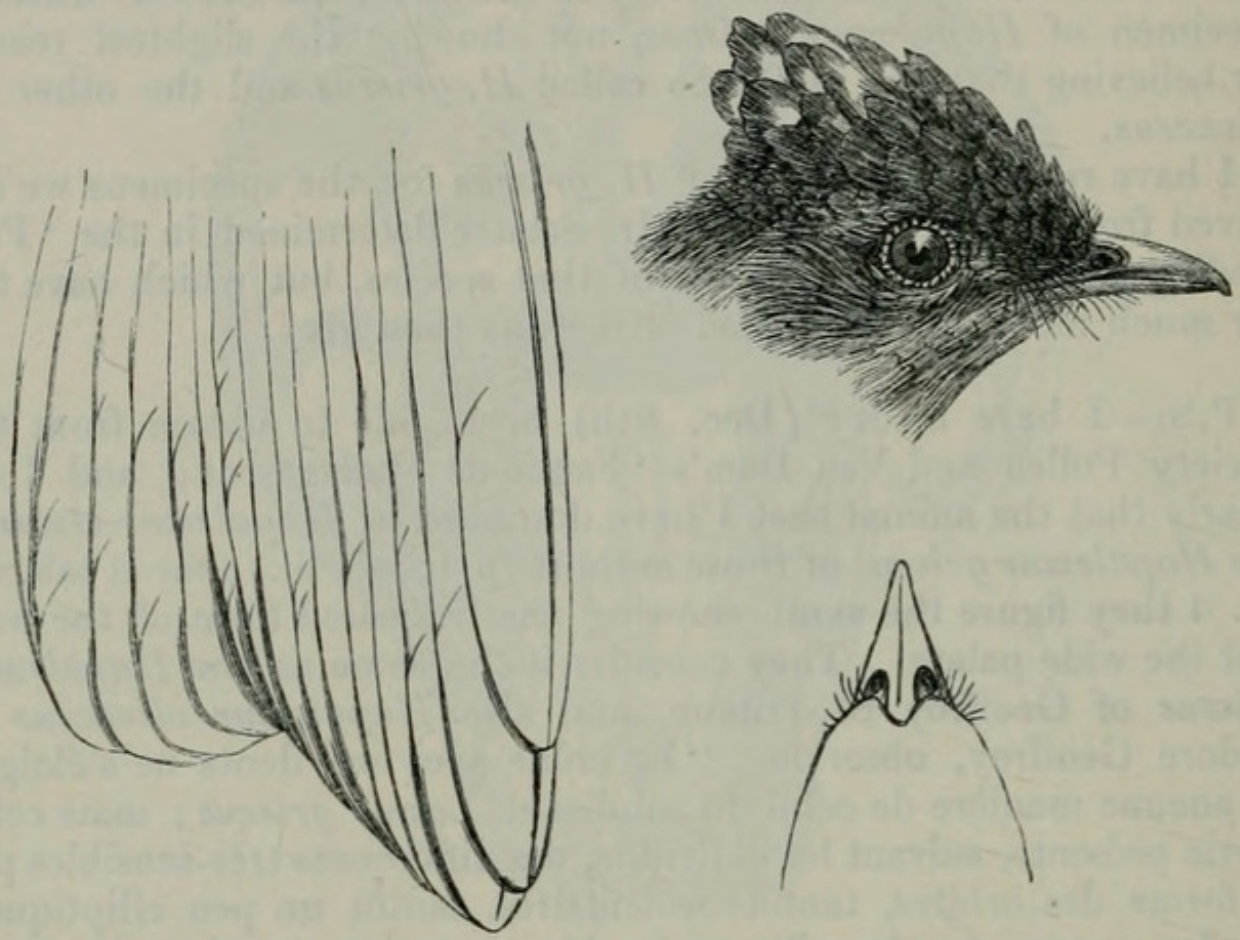

Elainea gigas.

I formerly referred this Elainea to the Muscipeta albiceps of Lafr. et D'Orb., but discovered my error on obtaining specimens of the latter bird from Eastern Peru (see P. Z. S. 1868, p. 174). $\quad \boldsymbol{E}$. gigas, as I now propose to call it, is the largest species of the genus that I am acquainted with, slightly exceeding in size even $E$. obscura. It is not unlike the latter species generally, but has a large and conspicuous white crest, the feathers of which are margined with the colour of the head.

2. Elainea fallax, sp. nov. (Fig. 2, p. 833.)

Elainea, sp. ex Jamaica, Sclater, P. Z. S. 1860, p. 314.

E. fallax, Sclater, P. Z. S. 1861 , p. 407, et Cat. Am. B. p. 217 (descr. nulla!).

Supra obscure olivacea, capite nigricantiore, pilei medii plumis ad basin albis: alis extus nigricantibus, tectricibus albo terminatis, secundariis hoc colore extus marginatis; primariis extus olivaceo anguste fimbriatis: cauda fusca, rectricibus extus olivaceo anguste fimbriatis: subtus pallide favida, subalaribus flavidis, remigum marginibus internis albescentibus: 
rostro corneo, mandibula ad basin pallide carnea, pedibus fuscis : long. tota $5 \cdot 2$, ala $2 \cdot 5$, cauda $2 \cdot 4$, tarsi $0 \cdot 6$.

Hab. ins. Jamaica.

I find I have accidentally omitted hitherto to give a description of this species of Elainea, of which I obtained two skins some years ago along with a large series of other Jamaican birds.

Fig. 2.
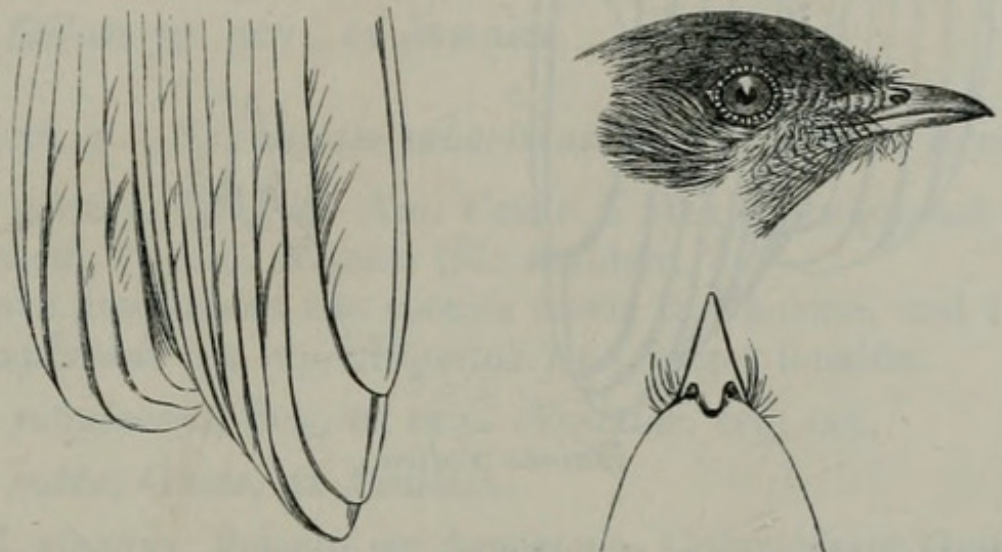

Elainea fallax.

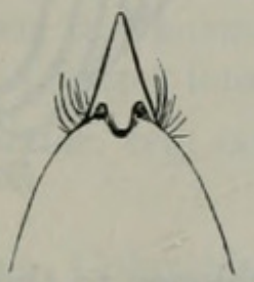

Mr. March (Pr. Ac. Phil. 1863, p. 290) suggests that this bird may be the young of $E$. cotta. But this cannot be the case, I think, as I have young and old of the latter. E. fallax belongs to the section with a concealed white crest, and has the wing-coverts terminated with white. E. cotta $\left(\sigma^{*}\right)$ has a bright yellow crest (see Gosse's figure, Ill. B. Jam. pl. xlv.), which is deficient in the female or young, and has plain unspotted wings. I have no doubt of the distinctness of the two species.

3. Elainea pudica, sp. nov. (Fig. 3, p. 834.)

Supra obscure olivacea unicolor; alis caudaque nigricantibus, alarum tectricibus albido terminatis, fascias duas alares ex. hibentibus; secundariis quoque extus albido late marginatis: cauda olivaceo extus anguste fimbriata: subtus pallide flavida, ventre medio dilutiore, gutture et pectore toto griseo perfusis: subalaribus et remigum marginibus internis pallide flavidis : rostro brevi, angustato, nigricante; mandibula, precipue ad basin, carneo: pedibus obscure corneis: long. tota $5 \cdot 5$, ala $2 \cdot 8$, cauda $2 \cdot 5$, tarsi $0 \cdot 6$.

Hab. Respubl. Colombica, Bogotá (Mus P. L. S.) ; Chiriqui (Arcé); Venezuela, prope Merida (Goering).

I have long had two Bogotá specimens of this Elainea in my collection under the MS. name now pubiished, and have lately obtained a third skin of it from Mr. Goering. From Arcé Salvin has recently also received a single example, apparently of the same species, and I was consequently in some hopes of being able to recognize in it one of the Central-American Elainece lately described 
by Mr. Lawrence. Failing to do this I have resolved to describe it as new.

Fig. 3 .
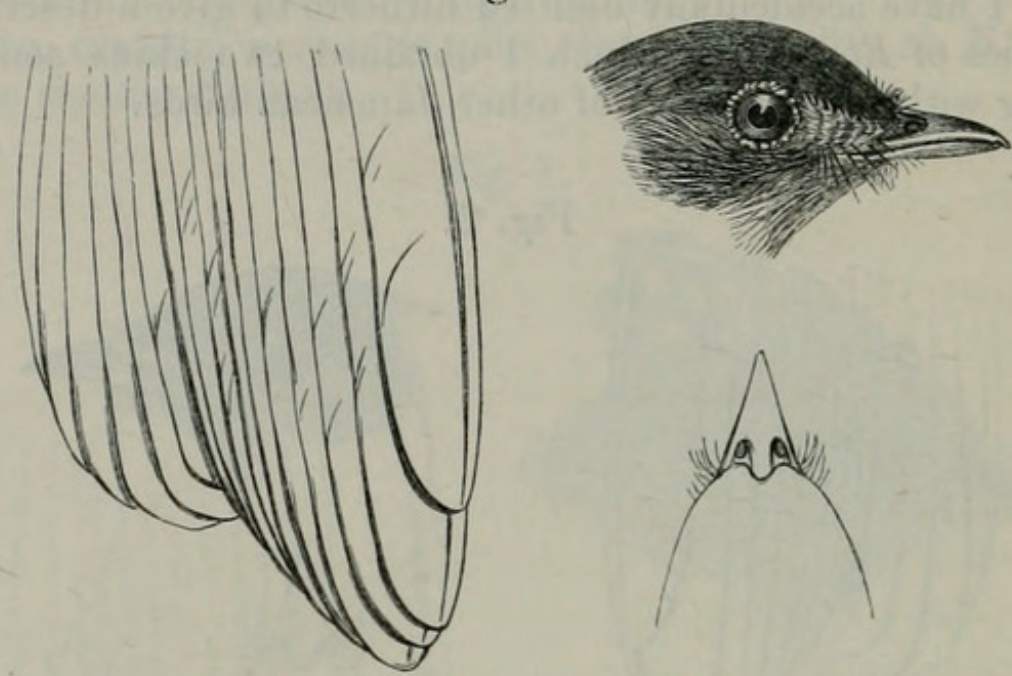

Elainea pudica.

This Elainea belongs to the third section of the genus as arranged in my "Index generis Elaineæ" *, having no vertical spot whatever. It is remarkable for its short and compressed bill.

I add a list of, with a few remarks on, the species of this very puzzling genus of Tyrannidæ represented in my collection.

Sect. A. Species capitis subcristati plumis intus albis.

1. E. pagana (Licht.); Scl. Cat. A. B. p. 216.

Under this name I now believe we shall have to reunite the species separated by me as $E$. subpagana and $E$. semipagana, and thus recognize one rather variable species extending from Southern Mexico to the wood-region of S.E. Brazil. I have now fifteen skins of this bird from various localities, and so have a better opportunity of judging of them than formerly. It should be mentioned, however, that there is much more white in the crests of northern specimens than in those from S.E. Brazil.

2. E. riisii, Scl.; Cat. A. B. p. 217 , ex ins. S. Thomas.

I am now a little doubtful about the validity of this species also. It may turn out to be only the same as the former; but more specimens are required, especially from the intervening islands between S. Thomas and Tobago.

3. E. albiceps (Lafr. et D'Orb.).

I am now disposed to unite under this name the specimens from E. Peru, Chili, and Buenos Ayres usually called E. modesta (Tsch.), and birds from Western Peru called E. albiceps by Mr. Salvin and myself (P. Z. S. 1868, pp. 174 et 568), although the latter are unusually large in size, and of a rather purer white on the throat. If this view be correct, the range of this species will be a wide one, from 
Eastern Peru to Buenos Ayres on the eastern side of the Andes, and Western Peru to Chili on the western side. I have also typical specimens of $E$. cristata and E. albivertex of Pelzeln (Orn. Bras. p. 177), and am rather inclined to consider these also inseparable from $E$. albiceps. I have already pointed out that my $\boldsymbol{E}$. griseigularis is the same bird (see P. Z. S. 1867, p. 327).

4. $E$. gigas, sp. nov., ex reip. Æquator. reg. orient.

5. E. pallatanga, Scl., ex. reip. Æquat. reg. occ.

6. E. fallax, sp. nov., ex Jamaica.

Sect. в. Sp. capitis subcristati plumis interne favis.

7. E. placens, Scl., ex Am. Centr. a Mexico usque ad isthmum Panamensem, et reip. Æquat. litt. occident.

We have now traced the species down to Panama, and I consider my $\boldsymbol{E}$. implacens (ex rep. Equator.) no longer tenable.

8. E. subplacens, Scl., ex reip. Æquator. reg. occ.

9. E. cotta, Gosse, ex Jamaica.

10. E. elegans, Pelzeln, ex Amazonia, Columbia et Guiana.

11. E. caniceps, Sw., ex Columbia et Peruvia.

Sect. c. Sp. pileo unicolori.

12. E. obscura (Lafr. et D’Orb.), ex Brasil. merid.

Under this (older) name I now unite the specimens arranged in my catalogue under $E$. olivacea and $\boldsymbol{E}$. rustica. I have additional skins from Ypanema (Natterer), and Lagoa Santa (Lund).

13. E. mesoleuca, Cab. et Heine, ex Brasil. merid.

14. E. frantzii, Lawrence, Ann. L. N.Y.vii. p. 173, ex Costa Rica.

15. E. pudica, Sclater, ex Columbia et Chiriqui.

16. E. affinis, Burm. Syst. Ueb. ii. p. 147 ; Pelz. Orn. Bras. p. 191, ex Brasil. int.

8. On Birds collected by Mr. George M. Whitely on the Coast of Honduras. By P. L. Sclater, M.A., Ph.D., F.R.S., and Osbert Salvin, M.A.

Mr. George M. Whitely went out to Honduras in the autumn of 1869 in company with the contractors engaged upon the first section of the Interoceanic line, and remained about six months in that country. Mr. Whitely's health unfortunately gave way; and he was consequently obliged to return home with much smaller collections than would otherwise have been the case. But we think it nevertheless expedient, in the interests of geographical distribution, to place on record an exact list of the species of birds obtained in 
this district, to which we have added a few notes where such explanations are called for.

The previous authorities on the birds of the Republic of Honduras are two only.:-

1. Mr. Moore's list of Leyland's collections in Honduras, Belize, and Guatemala, given in P. Z. S. 1859, p. 50.

2. Mr. G. C. Taylor's articles on the birds collected and observed during his journey across the isthmus from Fonseca Bay to Omoa in $1857-8$, published in 'The Ibis' for 1860 .

Mr. Whitely's series of about 520 skins was obtained in the vicinity of Puerto Cabello, Julian, Medina, and San Pedro. The three latter places are situated in the low forest-lands on the Chamelicon river, San Pedro, the furthest inland being not more than 30 miles from Puerto Cabello, the Atlantic terminus of the proposed railway. These specimens are referable to 135 species, of which the list is subjoined, the nomenclature, as usual, being that of Sclater's 'Catalogue of American Birds.'

Fam. Turdide.

*1. Turdus tristis.

2. - grayi.

3. Galeoscoptes carolinensis.

Fam. Troglodytide.

4. Campylorhynchus capistratus.

5. Thryothorus maculipectus.

6. modestus.

Fam. Sylvicolide.

7. Henicocichla auricapilla.

8. noveboracensis.

9. Helminthophaga peregrina.

10. Dendræca coronata.

11. carulea.

12. - pennsylvanica.

13. — estiva.

14. Geothlypis trichas.

Fam. Vireonide.

15. Icteria viridis.

16. Vireosylvia olivacea.

17. Hylophilus decurtatus.

Fam. Hirundinide.

18. Progne leucogastra.

Fam. Carebida.

19. Coreba cyanea.

20. Chlorophanes guatemalensis.
Fam. TANagride.

21. Euphonia hirundinacea.

22. Calliste larvata.

23. Tanagra diaconus.

24. - abbas.

25. Ramphocelus sanguinolentus.

26. - passerinii.

27. Pyranga astiva.

28. Phonicothraupis ruficoides.

29. Eucometis spodocephala.

30. Saltator atriceps.

31. - grandis.

32. magnoides.

33. Pitylus poliogaster.

Fam. Fringillidde.

34. Hedymeles ludovicianus.

35. Guiraca concreta.

36. Spermophila moreleti.

37. - corvina.

38. Volatinia jacarina.

39. Cyanospiza ciris.

40. - cyanea.

41. Euspiza americana.

Fam. Icteride.

42. Ocyalus wagleri.

43. Ostinops montezumae.

44. Cassiculus prevosti.

45. Icterus baltimorensis. 
*46. Icterus mesomelas.

47. - prosthemelas.

48. - spurius.

49. Quiscalus macrurus.

Fam. Corvide.

50. Cyanocorax guatemalensis.

*51. Psilorhinus mexicanus.

Fam. Dendrocolaptide.

52. Synallaxis erythrothorax.

53. Dendromanes anabatinus.

54. Dendrornis eburneirostris.

*55. - nana.

56. Picolaptes compressus.

Fam. Formicariide.

57. Thamnophilus melanocrissus.

58. — affinis.

59. Cercomacra tyrannina.

60. Formicivora boucardi.

Fam. Tyrannide.

61. Attila citreopygius.

62. Todirostrum cinereum.

63. Mionectes assimilis.

64. Elainea subpagana.

65. Myiozetetes texensis.

66. Myiodynastes luteiventris.

67. Rhynchocyclus cinereiceps.

68. Megarhynchus mexicanus.

69. Pitangus derbianus.

70. Contopus virens.

71. Empidonax flaviventris.

72. minimus.

73. Myiarchus lawrencii.

74. cooperi.

75. Tyrannus melancholicus.

76. - pipiri.

Fam. Cotingide.

77. Tityra personata.

78. fraseri.

79. Hadrostomus aylaia.

80. Heteropelma verce pacis.

81. Pipra mentalis.

82. Chiromacharis candai.
Fam. Момотіdе.

83. Momotus lessoni.

84. Eumomota superciliaris.

Fam. Alcedinide.

85. Ceryle torquata.

86. - cabanisi.

87. _ superciliosa.

Fam. Galbulida.

88. Galbula melanogenia.

Fam. Trogonide.

89. Trogon melanocephalus.

Fam. Caprimulgide.

90. Nyctidromus albicollis.

Fam. Trochilide.

91. Lampornis prevosti.

92. Florisuga mellivora.

93. Petasophora delphina.

Fam. Cuculide.

94. Crotophaga sulcirostris.

95. Piaya melheri.

*96. Coccyzus minor.

Fam. Ramphastide.

97. Ramphastus carinatus.

98. Pteroglossus torquatus.

99. Aulacorhamphus prasinus.

Fam. Picida.

100. Dryocopus scapularis.

101. Celeus castaneus.

102. Centurus santacruzi.

103. - pucherani.

*104. Picumnus olivaceus.

Fam. Psittacide.

105. Conurus astec.

106. Chrysotis guatemala.

107. - autumnalis.

108. Caica hamatotis.

109. Pionus senilis. 


\section{Accipitres.}

110. Polyborus tharus.

111. Ibycter americanus.

112. Herpetotheres cachinnans.

113. Spizaëtus tyrannus.

114. Urubitinga anthracina.

115. Geranospiza nigra.

116. Accipiter bicolor.

117. Micrastur guerilla.

118. Asturina plagiata.

119. - ruficauda.

120. Cymindis cayennensis.

121. Tinnunculus sparverius.

122. Hypotriorchis rufigularis.

\section{Columbe.}

\section{Columba rufina.}

124. Melopelia leucoptera.

125. Chamapelia rufipennis.
126. Leptoptila albifrons.

127. - plumbeiceps.

Cracide.

128. Crax globicera.

129. Ortalida vetula.

Tinamide.

130. Crypturus boucardi.

Limicole.

131. Egialites vociferus.

132. Rhyacophilus solitarius.

RALLIDE.

133. Aramides albiventris.

134. Heliornis fulica.

LARIDE.

135. Anous stolidus.

On looking through this list it becomes apparent that the ornithology of this part of Honduras, so far at least as is shown by Mr. Whitely's collection, differs in hardly any respect from that of the lowlands of Vera Paz, which has been already thoroughly explored. Out of these 135 species there are only three (Dendrornis nana, Coccyzus minor, and Picumnus olivaceus) that have not been observed in the above-named department of the adjoining Republic of Guatemala. Of these three exceptions, Coccyzus minor is of wide distribution and may likewise occur in Guatemala ; but the other two are southern species which appear here at the most northern limit of their range.

We subjoin a few remarks upon such of the above-mentioned species as require notice.

1. Turdus tristis, Sw.; Scl. et Salv. Ex. Orn. p. 145.

Out of three skins in Mr. Whitely's collection one belongs to the ashy-backed variety ( $T$. leucauchen, Sclater); the other two are intermediate between this and the Mexican form T. assimilis, Cab. This confirms us in our opinion (expressed Ex. Orn. p. 145), that the two species may be safely reunited under Swainson's older name. See also Mr. Salvin's remarks on this Thrush (P. Z. S. 1867, p. 132).

\section{Icterus mesomelas, Wagler.}

Mr. Cassin, in his study of the Icterida ( $\mathrm{Pr}$ Ac. Sc. Phil. 1867, p. 51), has separated the southern form of this bird as I. salvini, distinguishing it by the absence of the narrow external yellowish margin of some of the secondaries, and its larger size. We do not consider this proposed species to be well founded. In the present examples some possess the yellow margin, but others not. In a 
Bogotá skin in Sclater's collection this character is present. Nor can we find much difference as regards size, in specimens from different localities-Mexico, Honduras, Panama, and Bogotá.

51. Psilorhinus mexicanus (Rüpp.).

Mr. Whitely's skins belong, like Mr. Taylor's and all others from southern localities, to the white-tailed form. See our remarks, P. Z. S. 1869 , p. 363.

\section{Dendrornis susurrans (Jardine).}

Dendrocolaptes susurrans, Jard. Ann. N. H. xix. p. 81 .

Dendrornis susurrans, Eyton, Contr. Orn. 1852, p. 23 ; Sclater, Cat. A. B. p 165 ; Scl. et Salv. P. Z. S. 1868, pp. 167, 627, et 1869, p. 252.

Nasica susurrans, Lafr. Rev. Zool. 1850, p. 42.5 ; Léotaud, Ois. de Trin. p. 160.

Dendrornis nana, Lawr. Ibis, 1863, p. 181 (?).

Dendrornis nana, Scl. et Salv. P. Z. S. 1864, p. 355 ; et Salvin, P. Z. S. 1870 , p. 193 (certé).

After comparing Mr. Whitely's specimen of this Dendrornis with fifteen others from various parts of the Central-American isthmus (Costa Rica, Veragua, and Panama), which we have hitherto called D. nana (ex Lawrence), and with Venezuelan, Trinidad, and Tobago skins of D. susurrans, we have come to the conclusion that they all belong to one species. Upon one of the smaller-sized individuals $\mathrm{Mr}$. Lawrence appears to have established his $D$. nana; and we are inclined to suppose that the birds called D. guttatus (Ann. L. N.Y. vii. p. 292) and D. pardalotus* (ibid. viii. pp. 4, 180, and ix. p. 107) likewise belong to this same species.

We have never met with more than three other species of this genus of Dendrocolaptidæ from any district north of Panama. These are:-

1. D. eburneirostris. Mexico, Guatemala, and Honduras.

2. D. lachrymosa. Nicaragua, Costa Rica, Veragua, and Panama.

3. D. erythropygia. Southern Mexico down to Panama.

We are not acquainted with $D$. mentalis, recently described by Mr. Lawrence from Northern Mexico (Ann. viii. p. 48).

96. Coccyzus minor (Gm.).

See Sclater's remarks on this species, P. Z. S. 1870, p. 166.

\section{Picumnus olivaceus (Lafr.).}

This is the most northern locality yet recorded for any species of this genus. The specimens agree with Bogotá skins, and with those from Veragua received by Mr. Salvin (cf. P. Z. S. 1870, p. 212). No other Picumnus is known from north of Panama.

* A skin in the collection of Dendrocolaptida belonging to the Smithsonian Institution now under Sclater's examination, which is marked $D$. pardalotus in Mr. Lawrence's handwriting, certainly belongs to D. susurrans.

Proc. Zool. Soc.-1870, No. LVI. 
9. Descriptions of five new Species of Birds from the United States of Columbia. By P. L. Sclater, M.A., Ph.D., F.R.S., and Osbert Salvin, M.A., F.L.S.

\section{(Plate LIII.)}

\section{Pheucticus uropygialis, sp. nov.}

Pheucticus aureoventer, Sclater, P. Z. S. 1855, p. 154.

Supra niger; rectricum alarium fasciis duabus cum speculo alari alhis; uropygii plumis flavis nigro terminatis: subtus ad medium pectus niger, abdomine flavo, lateribus nigro variegatis; tectricibus subalaribus flavis : cauda nigra, rectricibus lateralibus albo terminatis: rostro nigro ad basin plumbeo, pedibus nigris : long. tota 8 , alce $4 \cdot 5$, cauda $3 \cdot \bar{T}$ poll. Angl.

$\mathrm{Hab}$. In int. Columbia.

Mus. P. L. S. et S.-G.

Obs. Similis P. aureoventri, Lafr. et D'Orb., ex Bolivia, sed uropygio flavo diversus.

We found this species on a "Bogotá" skin in Sclater's collection. Mr. C. Wyatt has lately obtained a specimen of the same bird in the Sierra Ocaña of Columbia. It is probable that Fraser's skins from Riobamba, Ecuador, referred by Sclater (P. Z. S. 1858, p. 551) to $P$. aureoventer may belong here; but the specimens are not adult, and show no black on the throat. We may also remark that they have the crissum white, and not yellow as in the Bogotá bird. There are likewise Bogotá skins of this species in the collection of Messrs. Salvin and Godman, and in the British Museum.

There appear to be now known five species of this form, viz. :-

(1) P. chrysopeplus (Vig.). From Western Mexico ; lately discriminated by Finsch, Abh. Nat. Ver. z. Bremen, 1870, p. 339 .

(2) P. tibialis, Lawr. Ann. Lyc. N. Y. viii. p. 478. From Costa Rica and Veragua.

(3) P. chrysogaster (Less.); Scl. Cat. Am. B. p. 100 (syn. excl.). From Ecuador and Venezuela.

(4) P. uropygialis. From the highlands of Columbia.

(5) P. aureiventris, Lafr. et D'Orb. From the highlands of Bolivia.

2. Synallaxis wyatti, sp. nov.

Supra fusca, nigro striata: tectricum alarium marginibus et remigum macula magna basin occupante cum subalaribus rufis: subtus pallide ochracea, pectore paulo obscuriore et punctis paucis nigris asperso, gula alba flavicante tincta: caude rectricibus duodecim, tribus lateralibus rufis, scapis nigris, ceteris nigricantibus rufo paulum variegatis : rostro elongato, acuto, corneo, ad basin pallidiore: pedibus fuscis: long. tota 6 , ala 2 , caude rectr. lat. 1·6, med. $2 \cdot 8$, rostri a rictu $0 \cdot 7$.

Hab. Paramo of Pamplona, New Granada ( $W$ yatt).

Mus. P. L. S. 


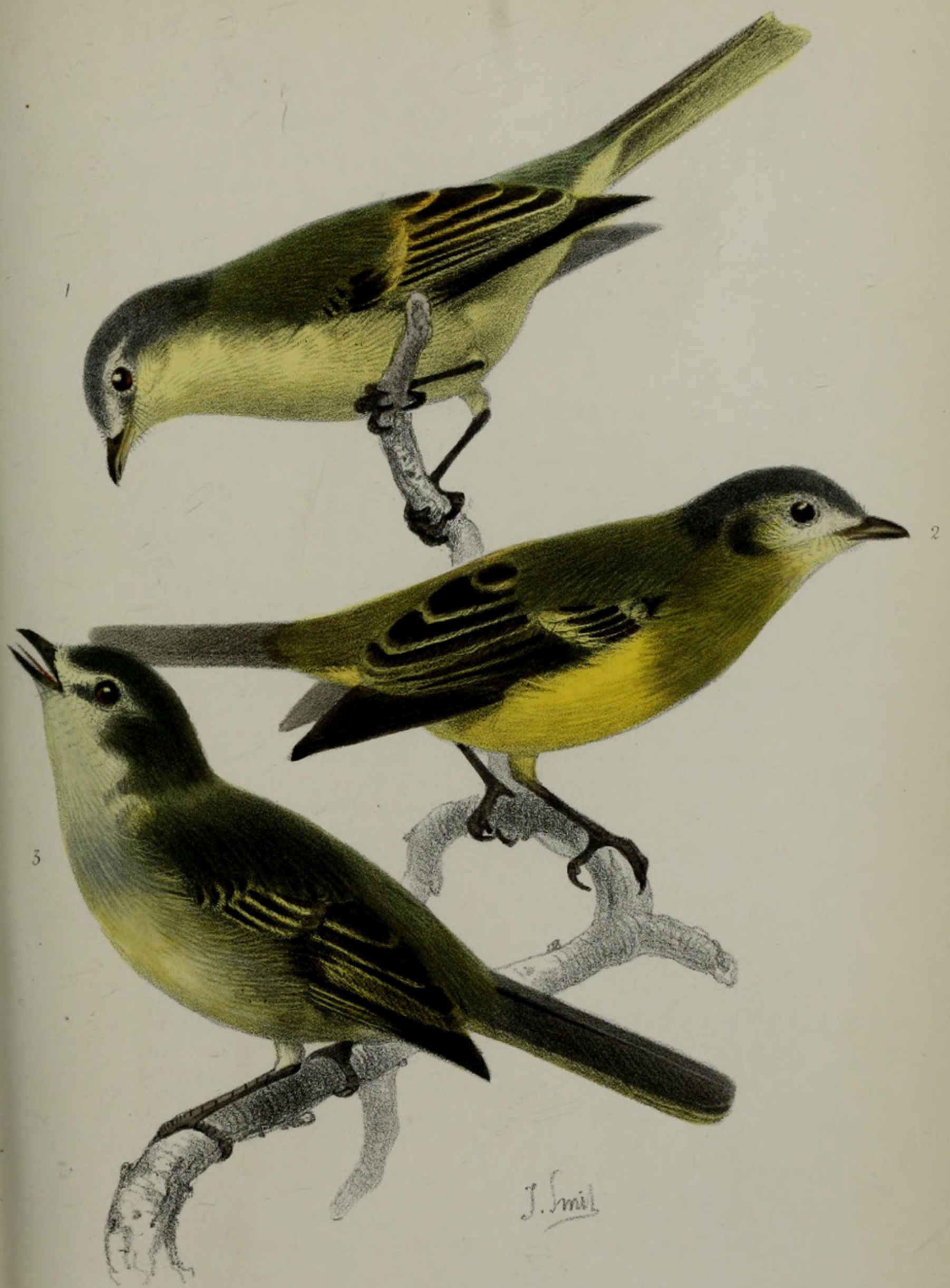



Obs. Proxima $S$. anthoidi, sed striis dorsi angustioribus et crebrioribus, et rectricibus externis rufis distinguenda.

3. Tyranniscus leucogonys, sp. nov. (Plate LiII. fig. 1.)

Tyranniscus, sp., Scl. Cat. Am. B. p. 216. no. 1320.

Supra olivaceus; pileo toto dilute cinereo, fronte et capitis lateribus albo variegatis; alis caudaque fusco-nigricantibus, alarum tectricibus et remigibus favicanti-olivaceo marginatis, rectricum marginibus olivaceo stricte fimbriatis : subtus pallide limonaceo-flavus, subalaribus limonaceo-favis : maxilla cornea, mandibula alba, pedibus corneis : long. tota 4 , ale $2 \cdot 4$, cauda $1 \cdot 7$, rostri a rictu $0 \cdot 5$.

Hab. In int. Columbia.

Mus. P. L. S.

Two Bogotá skins of this small Tyrant are in Sclater's collection, one having been purchased from Bell of New York in 1856, and the second more recently obtained from the Maison Verreaux.

The species is of about the same size and general appearance as $T$. cinereiceps, Scl., but wants the conspicuous black ear-coverts and the broad whitish spots on the wing-coverts which distinguish that species. It is likewise of a much paler yellow below. The wings are rather long and pointed, the second, third, and fourth primaries being nearly equal and longest.

\section{Tyranniscus improbus, sp. nov. (Plate LIII. fig. 3.)}

Supra olivaceus ; capite obscuriore, frontem versus nigricante; fronte ipsa et regione oculari utrinque albicantibus; loris nigris; alis caudaque nigricantibus, alarum tectricibus et secundariis flavo anguste limbatis; rectricibus extus olivaceo fimbriatis: subtus dilute flavidus, gula et pectore superiore albicantibus, cinereo sublavatis; subalaribus et campterio alari flatidis : rostro et pedibus nigris: long. tota $4 \cdot 5$, ala $2 \cdot 2$, cauda $1 \cdot 9$, rostri a rictu $0 \cdot 5$.

$H a b$. In Andibus Venezuelæ et Columbiæ.

Mus. P. I. S.

Obs. Sp. Tyrannisco vilissimo, ex Guatemala, maxime affinis, sed pectore flavidiore et pileo nigricantiore, ut videtur, diversus.

The first specimen of this Tyranniscus which occurred to us was obtained near Merida by Mr. Goering*, but we did not venture to describe it from a single specimen. More recently in Mr. C. Wyatt's collection we found a second example, which was obtained by that gentleman in the Sierra Ocaña.

\section{Tyranniscus griseiceps, sp. nov.}

Tyranniscus, sp., Scl. Cat. Am. B. p. 216. no. 1318 ; Scl. \& Salv. P. Z. S. 1869 , p. 252.

Supra dilute olivaceus, pileo cinereo; fronte et capitis lateribus albo mixtis : alis caudaque fusco-nigricantibus, alarum tectricum et secundariorum marginibus in olivaceum trahentibus, rectricum marginibus externis dorso concoloribus: subtus limonaceo-flavus, gut- 
ture albicante, subalaribus flavidis: rostro dilatato, corneo, pedibus obscuris: long. tota 4, alce 2, cauda 1.9.

Hab. Western Ecuador, Pallatanga and Babahoyo (Fraser); Venezuela, Lake of Valencia (Goering).

Mus. P. L. S.

We base this species upon two skins obtained by Fraser in Ecuador, which have hitherto stood in Sclater's collection under a MS. name. The single specimen, above referred to, obtained by $\mathrm{Mr}$. Goering nearly agrees with these, and belongs, we have little doubt, to the same species.

The bill is rather flatter and broader at the base than in other species of the genus Tyranniscus, the wings rather shorter, and the tail somewhat longer. The margins of the wing-coverts, instead of being distinctly defined as in $T$. vilissimus and its two allies $T$. parvus and T. improbus, are not nearly so bright and conspicuous. The second, third, fourth, and fifth primaries are nearly equal and longest.

The three species above described increase the number of the members of this obscure genus to nine, which may be arranged as follows :-

\section{Clavis generis Tyrannisei.}

a. tectricibus alarum nigris, albo terminatis.

$\{$ regione auriculari olivacea : pileo nigro

1. nigricapillus.

regione auriculari nigra: pileo cinereo

2. cinereiceps.

$b$. tectricibus alarum fuscis, flavo distincte marginatis.

$a^{\prime}$. pileo dorso concolori: fronte aurea

$b^{\prime}$. pileo cinereo: fronte albida.

$a^{\prime \prime}$. gutture albo aut grisescente.

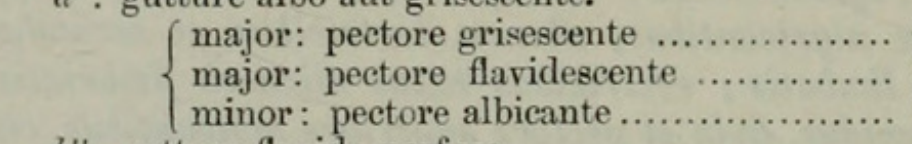

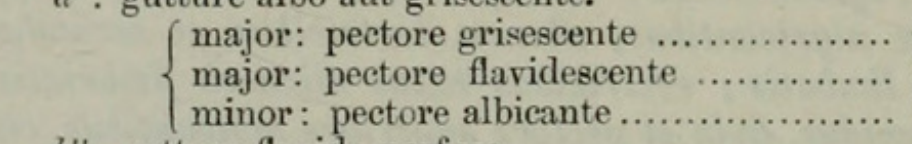

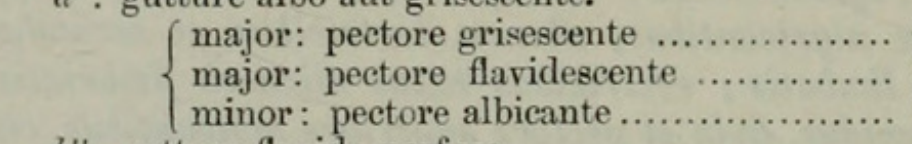
\{ major: mandibula albicante
minor: mandibula nigra.
4. vilissimus
5. improbus.
6. parvus.
7. leucogonys.
8. gracilipes.

$b^{\prime \prime}$. gutture flavido perfuso.

3. chrysops.

c. tectricibus alarum fuscis, olivaceo obsolete marginatis

The synonymy and localities of these nine species are as follows :-

(i) Tyranniscus nigricapillus.

Tyrannulus nigricapillus, Lafr. Rev. Zool. 1845, p. 341; Sclater, P. Z. S. 1860 , p. 93.

Tyranniscus nigricapillus, Cab. et Hein. Mus. Hein. ii. p. 57; Sel. Cat. Am. B. p. 216.

Hab. Ecuador, Puellaro (Fraser); Bogotá (Mus. P. L.S.).

(2) Tyranniscus cinereicers. (Plate LIII. fig. 2.)

Tyrannulus cinereiceps, Sclater, P. Z. S. 1860, p. 69.

Tyranniscus cinereiceps, Scl. Cat. Am. B. p. 216.

Hab. Pallatanga, Ecuador (Fraser); Bogotá (P.L.S.).

(3) Tyranniscus chrysops.

Tyrannulus chrysops, Sclater, P. Z. S. 1858, p. 458, 1859, p. 144, et 1860 , p. 93 . 
Ty:anniscus chrysops, Sclater, Cat. Am. B. p. 216.

Tyrannulus flavidifrons, Scl. P. Z. S. 1860, p. 69.

Tyranniscus favifrons, Scl. Cat. Am. B. p. 216 ; Cab. et Hein. Mus. Hein. ii. p. 56 (1859).

Hab. Ecuador and Bogotá (P. L.S.); Sierra Ocaña (Wyatt).

(4) Tyranniscus vilissimus.

Elainea vilissima, Sclat. et Salv. Ibis, 1859, p. 122, pl. 4. f. 1; Salvin, Ibis, 1860, p. 194.

Tyranniscus vilissimus, Scl. Cat. Am. B. p. 216.

Hab. Guatemala.

(5) Tyranniscus improbus.

Hab. Venezuela, Merida (Goering); Sierra Ocaña (Wyatt).

(6) Tyranniscus parvus.

Tyranniscus parvus, Lawr. Ibis, 1862, p. 12 ; Ann. N. Y. Lyc. vii. p. 473 ; Scl. \& Salv. P.Z. S. 1864, p. 359 ; Salv. P. Z. S. 1867 , p. 147.

Hab. Panama (M`Lennan); Veragua et Costa Rica (Arcé).

( 7 ) Tyranniscus leucogonys.

Hab. Bogotá (P. L.S.).

(8) Tyranniscus gracilipes.

Tyranniscus, sp. 1317, Scl. Cat. A. B. p. 216.

Tyranniscus gracilipes, Sclater, MS.; Scl. \& Salv. P. Z. S. 1867, p. 981.

Myiopatis pusilla, Pelz. Orn. Bras. p. 106.

Hab. Eastern Peru, Pebas (Hauxwell).

(9) Tyranniscus griseiceps.

Hab. Ecuador; Babahoyo and Pallatanga (Fraser).

6. Trogon chionurus, sp. nov.

Trogon viridis, Scl. et Salv. P. Z. S. 1864, p. 364 ; Lawr. Ann. L. N. Y. vii. p. 290.

Similis $\mathbf{T}$. viridi, sed maris rectricibus externis fere omnino albis, ita ut cauda clausa omnino alba esse videtur. Femina etiam rectricum externarum apices late albos ostendit.

Hab. Panama (M'Leannan).

Mus. S.-G. et G. N. Lawrence.

We have examined numerous specimens of this Trogon from Panama, and have hitherto referred it to $T$. viridis. We convinced ourselves some time ago, on examining an example from Mr. Lawrence's collection, that it was not really $T$. viridis, but were then doubtful whether it might not be $T$. venustus, Cab. et Hein. Mus. Hein. ii. p. 194. On going into the question again, aided by additional skins of $\boldsymbol{T}$. viridis from various localities, we feel convinced that 
T. venustus (as characterized, $l$. $c$. s.) cannot be considered really distinct from $T$. viridis. We have specimens of this bird now before us from Rio, Bahia, Matto Grosso, Eastern Venezuela, and Bugotá, and can find no constant differences amongst them, although there is considerable dirersity of tint in the colour of the lower back, and some specimens approach to what Dr. Finsch has recently proposed to call T. cyanurus (P. Z. S. 1870, p. 559).

On the other hand three Panama skins (in Mus. S.-G.) present the remarkable character of the outer tail-feathers above mentioned. The first outer pair are all pure white except a narrow basal patch concealed by the tail-coverts. Of the second pair, considerably more than the apical half is white. In the third pair the white apices measure $2 \mathrm{in}$. in length. When the tail is closed the under surface appears perfectly white. We therefore call this bird T. chionurus.

We have seen other examples of this Panama species in Mr. Lawrence's and Mr. Gould's collections.

\section{On certain points in the Anatomy and Economy of the Lampreys. By George Gulliver, F.R.S.}

\section{BLOOD-CORPUSCLES.}

Red Corpuscles.-For the discovery of the now well-known circular shape of the red blood-corpuscles of the Lamprey, we are indebted to that eminent physiologist Rudolph Wagner. He likened them, as biconcave disks and otherwise, to those of Man and Mammalia; and as his figures and descriptions of those of the Lamprey are the only ones with which I am acquainted, it seems to me that a further account of them is yet desirable.

The majority of them are circular; only a few assume a slightly oval form, just as some circular red disks appear among the far greater number of the regular oval or suboval ones of osseous fishes. The red corpuscles of the Lamprey are but rarely or exceptionally biconcave disks, and then only from irregular or unequal depressions on the surfaces, scarcely ever from those two symmetrical concavities which are so truly characteristic of the blood-disk of Apyrenæmatous vertebrates. On the contrary, the red blood-corpuscles of the Lamprey are regularly either flat or slightly biconvex (fig. 1, $a$ and $b$ ); but this form is liable to much variation from one or more dents caused by puckering or contractions inwards either of the surface or of the margin of the soft disk; often a depression on one side and projection of the other produces a concavo-convex form; and, as a rule, the disk is proportionally and absolutely thicker than that of Apyrenæmatous vertebrates.

The nucleus (fig. 2 ) is very distinct, either circular or suboval, and sufficiently thick to prevent two such central depressions on the faces of the red corpuscle as would make it a synmetrical biconcave disk.

Hence the comparison of the blood-disks of the Lamprey to 
those of Man, so commonly adopted, after Wagner, seems to demand reconsideration. Notwithstanding their correspondence in the circular outline, they differ essentially in structure and size, in which respect the Lamprey's red corpuscle truly conforms to the pyrenæmatous type. No blood-disks of any Apyrenæmatous vertebrate are known to be either regularly nucleated, so large, or so thick as those of the Lamprey; nor is the flat or slightly biconvex form of this fish's blood-disks the regular shape of those of the Apyrenæmata. But though the size may and does, so far as is yet known, thus afford a good diagnostic of existing vertebrates, it does not necessarily follow that Mammalia have never lived with much larger red blood-corpuscles than any ever seen in this class. For, after my proofs that the Edentata are truly characterized by the largeness of these corpuscles (Lecture iii. Med. Times and Gaz. Sept. 13, 1862; Proc. Zool. Soc. Feb. 10, 1870), it seems highly probable that the huge and extinct species of this Aprenæmatous order had blood-disks quite as large as those of the Lamprey.

Pale Globules, fig. 3.-Of this fish these globules are of the same shape, size, and structure so well known in other vertebrates; and hence, while in Apyrenæmata the pale globules are commonly larger than the red corpuscles, in the Lamprey and other Pyrenæmata the pale globules are generally more or less smaller than the red corpuscles.
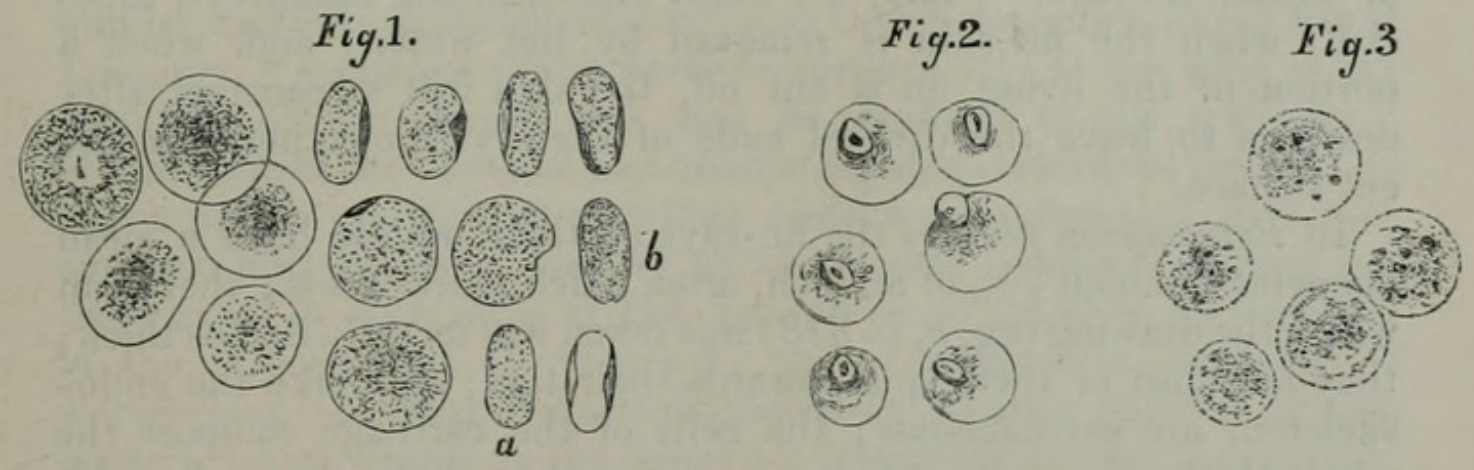

4000 ths

of an Inch.

Of the above woodcut, fig. 1 represents the red corpuscles of Petromyzon planeri as seen in the liquor sanguinis- $a, b$, corpuscles of regular shape seen edgewise; fig. 2, red corpuscles with their nuclei exposed by the action of sulphurous acid; and fig. 3, pale globules of the blood. They are all drawn, like the engravings referred to in the Proc. Zool. Soc. Feb. 10, 1870, to a scale of which each division stands for one four-thousandth of an English inch.

Size of the Corpuscles.--In the following measurements are given, in vulgar fractions of an English inch, the average dimensions of the corpuscles of the blood of Man and of the Lampreys (Petromyzon planeri, P. fluviatilis, and Ammocoetes branchialis). There is so little difference between the blood-copuscles of these fishes that one description may serve for all three of them. Formerly I accidentally 
noted a measurement of small corpuscles of Ammocœetes for an average.

$$
\begin{aligned}
& \text { Man, diameter of the disk .............. } \frac{1}{3200} \\
& \text { " thickness of the disk. ............... } \frac{1}{12,400} \\
& \text {, diameter of pale globules............ } \frac{1}{3000} \\
& \text { Lamprey, diameter of the disk ............ } \frac{1}{2134} \\
& \text {, thickness of the } \operatorname{disk} \ldots \ldots \ldots \ldots \ldots \ldots \frac{1}{6200} \\
& \text { " diameter of nucleus } \ldots \ldots \ldots \ldots \ldots . \quad \frac{1}{6400} \\
& \text { " diameter of pale globules .......... } \frac{1}{3000}
\end{aligned}
$$

\section{Fins.}

Fin-rays. - The Lampreys, under the head of Dermopteri, are usually described as "without fin-rays ;" see, for example, Mr. Couch's recent 'History of the Fishes of the British Islands,' vol. iv. p. 38., and the still later 'Comp. Anatomy of Vertebrates,' vol. i. p. 7. Yet these rays are plainly visible in more than one species of Lamprey, and so thickly set in the dorsal fin that it might be difficult to count them; and according to Prof. Huxley (Introduction to the Classification of Animals, 8vo, London 1869, p. 63), " it is questionable whether any fish exists altogether devoid of the system of median fin-rays." They are easily shown in the Lampreys, especially when the fin-skin is removed by hot water; and, when a portion of the living fin is cut off, the skin will so contract after death as to leave the divided ends of the rays projecting from the cut surface.

In Petromyzon planeri the fin-rays at their middle have a mean diameter of about $\frac{1}{200}$ of an inch, often much more or less; that from which the drawing (fig. 8, p. 848) was taken was scarcely half as thick; they are most of them split towards their tips; and, like the endoskeleton, are cartilaginous; the cells of the cartilage compose the whole thickness of the fin-ray, are of a somewhat polygonal shape, mostly oblong, closely packed together, with their long axes across the ray, and each cell is about $\frac{1}{2000}$ of an inch in diameter. Each finray has a sheath of longitudinal fibres that have elongated nuclei.

Marginal Papilia, fig. 7, p. 848.-The free edge of the dorsal fin has a pretty fringe of a single row of conical papillæ. In Planer's Lamprey they have an average length of about $\frac{1}{500}$ of an inch, and half that breadth; and they are thickly sprinkled with black pigmentgranules. In $\boldsymbol{P}$. fluviatilis the marginal papillæ are smaller and fewer than in $P$. planeri.

Eye.

Lens-fibres. - Since the discovery, by Brewster, of the deeply indented and interlocking edges of these fibres in the Cod, this has been adopted as a common character of fishes. But the indentations and the diameter of these fibres are so different in diverse species as to afford valuable taxonomic characters in the class. Thus, e.g., while 
of Alosa finta, Mugil capito, and most other osseous fishes the external lens-fibres are so deeply indented as to be well represented in that philosopher's engraving from the Cod, these fibres in the Eel have merely a slight serrature or unevenness at their margins, the jaggedness not more distinct than in the same part of various higher vertebrates, as the English Batrachians, and the Rook and Rat; nor in many cartilaginous fishes is the marginal denticulation of the lensfibres much more marked, as may be witnessed in Acipenser sturio, Galeus vulgaris, Raia microcellata, and numerous others.

And in the Lamprey even this feeble serrature of the edges of the lens-fibres disappears so completely that they are quite smooth and entire, except a very faint roughness towards the ends of the inner fibres near the poles of the lens. And the kernel of the lens is not so hard, tough, and difficult to be teazed out as in osseous fishes; while in these last the lens-fibres are commonly much broader than those of the Lampreys; as may be seen engraved (Monthly Journ. Microsc. Science, April 1869) from the River-lamprey, the Eel, and the Pike.

\section{Organs of Generation.}

External Genital Papilla, figs. 4 and 5, p. 848. - Some notices of these parts occur in the books of systematic ichthyology. Thus Yarrell says that "the roe, in both sexes, escapes by a small membranous sheath, which has internally at its base five apertures, one leading upwards to the intestine ;" and Couch describes, in the Silver Lamprey, "a process which perhaps appears only at the time of the shedding of the spawn, and may be confined to one sex only." Wagner mentions "conical and often elongated structures, resembling intromittent organs, in Syngnathus, Gobius, Lepadogaster, Blennius, and also Petromyzon;" but as of the genital papillæ and their tubular canal in both sexes of the Lampreys no notice is given either in the 'Cyclopædia of Anatomy,' the 'Comparative Anatomy of Vertebrates,' or Max Schultze's elaborate memoir on Petromyzon planeri, I have drawn up the following descriptions from this species.

Penis or Genital Papilla of the Male, fig. 4.-This is very con spicuous during the height of the spawning-season in spring, and when flaccid is about an eighth of an inch long, a thirtieth thick, and of a conical shape. On the 20th of April, my son, while examining dead specimens of this fish under water, found that abundance of semen issued in a jet through the papilla, as from a syringe, when the abdomen was pressed between his thumb and finger; and that this seminal outlet was a central and perfect canal, or longitudinal tube, through which either air or a fine probe could readily be passed from the peritoneal cavity. When the semen was pressed out in a full stream along this canal, the penis was elongated and somewhat distended and erected, like an intromittent part for copulation. The organ has numerous minute blood-vessels, and is composed of a dense connective tissue with numerous connectivetissue corpuscles.

Female Genital Papilla, or Vulva, fig. 5.-At the same time we 
saw that those females which were distended with eggs had a similar genital papilla, only shorter and with a wider canal than in the male. Through this vulva the eggs, each about a fortieth of an inch in diameter, readily escaped in single file. The intimate structure of the organ is the same, and the tube a genito-urinal outlet, in both sexes.

From the above descriptions, it appears that during the spawningseason, the peritoneum of the Lamprey is not in either sex a shut sac, for it opens outward by the tubular canal, through and along the centre of the genital papillæ of the male and female-and that in each sex the genital outlet is single, with its external opening independent of and separate from the so-called cloaca.

Spermatic Filaments, fig. 6.-These were extremely abundant. Their mean length is $\frac{1}{2000}$ and their thickness $\frac{1}{30,000}$ of an inch. Though but little acted on by acetic acid, they do not preserve their shape well in drying.

Indeed the effect of this acid seems to indicate different chemical characters of the spermatozoa of different animals. While it has no effect on those filaments of most mammalia, it dissolves or destroys very quickly the spiral spermatozoa of birds; and yet the club. shaped spermatozoa of this class resist its action like those of mammalia, as more particularly noticed in the 'Proceedings' of this Society, July 26, 1842.
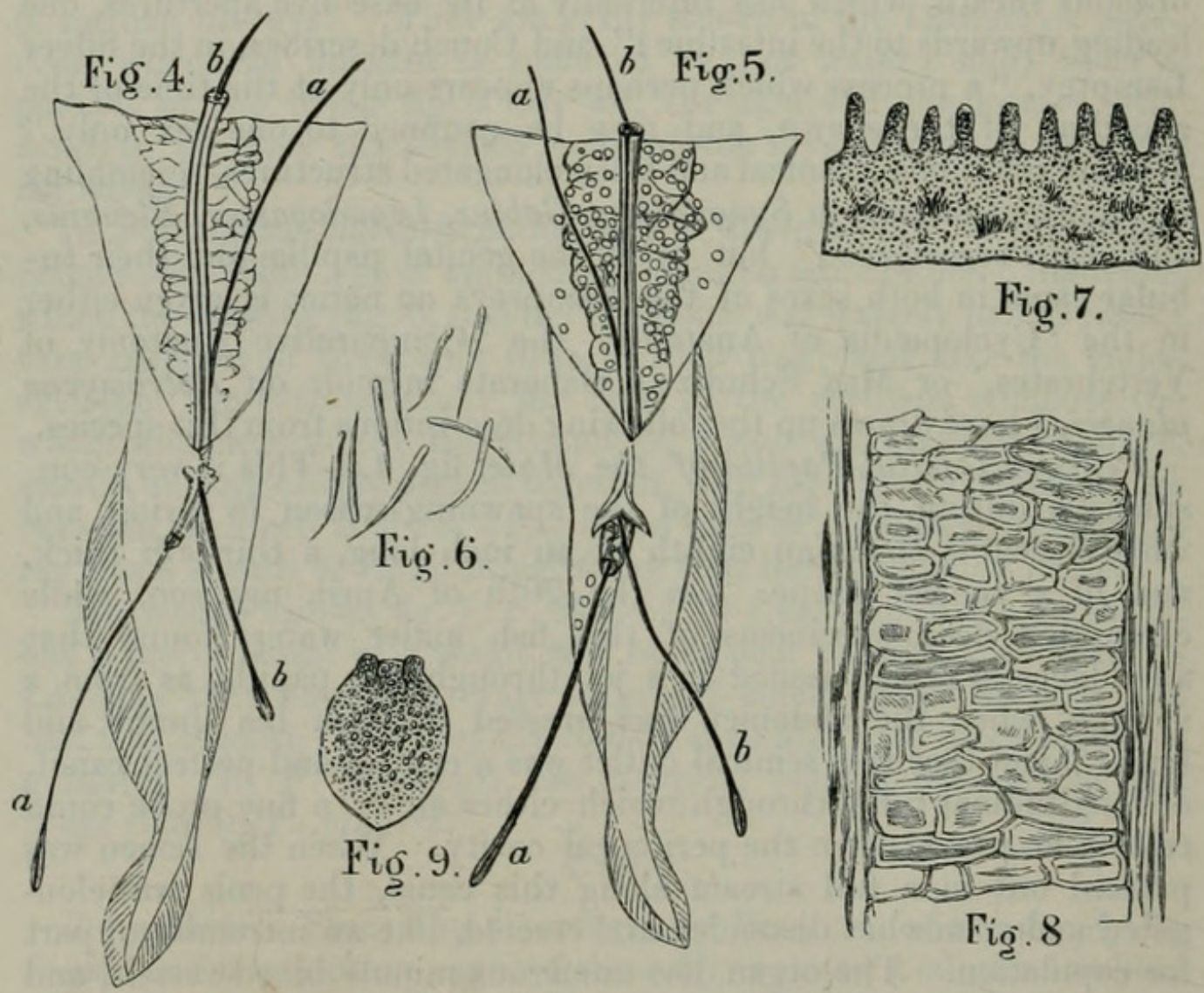

Fig.7.

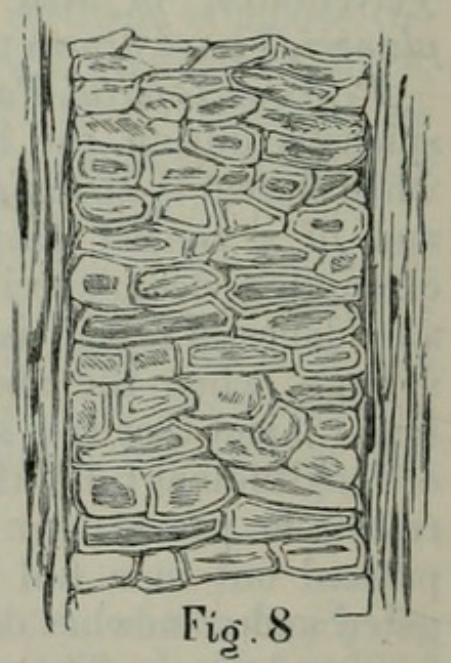

In the above woodcut, figs. 4 and 5 show the genital papillæ of the natural size-fig. 4 of the male, and fig. 5 of the female; in each 
the bristle $a \boldsymbol{a}$ is passed from the peritoneal sac, through the tubular genital outlet which perforates lengthwise the centre of the papilla ; the bristle $b b$ is passed along the inside of the intestine, and out at the anus. In the female, fig. 5, some ova are seen free in the abdomen, and others passing and passed through the canal of the vulva. Fig. 6, spermatic filaments, magnified about 700 diameters. Fig. 7, marginal papillæ of the dorsal fin, magnified about 75 diameters. Fig. 8 , a bit of fin-ray, its cartilage-cells and sheath-fibres, magnified about 600 diameters. Fig. 9, brain-worm, enlarged about 60 diameters. All the figures were taken from Planer's Lamprey.

Abundance of Ova.-The females of Planer's Lamprey are much distended with eggs in the spring. In a specimen of Petromyzon fluviatilis caught on the 20th December, 1868, eighteen inches long and six and a half ounces weight, I counted no less than 51,220 eggs, none of which were then detached from the ovary into the peritoneal cavity. Their average diameter was $\frac{1}{60}$ of an inch; and 394 of them, after having been drained of extraneous moisture, weighed one grain.

\section{Petromyzon planeri.}

I have seen this species in abundance at Dundrum in the north of Ireland; and it is remarkably plentiful in the river Stour at Cartterbury. During the spawning-season, which occurs here from the end of March until June, this Lamprey is so common in the shallow streams, and so intent on the procreative business, as to be taken in numbers by hand, much to the amusement of the idle boys, who indulge then in this simple and primitive sort of piscatorial sport. After June or July, these Lampreys entirely disappear, so that not a single specimen can be found, though the larval Ammocete is then, as before, to be caught. During the height of the spawning-season, Planer's Lamprey takes so little food that none is found in the alimentary canal, which is then contracted to a mere thread, while the Ammocete feeds freely and has its intestine distended accordingly.

\section{Entozoa.}

It is remarkable that a fish with its brain-case occupied by a mass of living worms equal to that of the cerebral substance should appear in perfect health and activity, exercising its generative functions with the greatest vigour; yet such is the case with Planer's Lamprey.

In the course of last spring my son was examining the brain of this fish, and found it infested by great numbers of what seemed to belong to the tribe of parasitic "platyelminthes." Of a single fish the entire brain was not larger than the aggregate bulk of the whole of these worms. On pursuing the inquiry, it was found that every Planer's Lamprey taken for us that season from the Stour river at Canterbury was thus infested; not a single specimen examined was exempt from these brain-worms. Their fut ure career and 
final destiny might afford important information for helminthology ; and the investigation would be easy now we have learned this station and phase of the worm. Hence I have given the sketch (fig. 9, p. 848), and hope soon to examine more fully the anatomy of this entozoon in fresh specimens.

The average length of each worm was $\frac{1}{60}$ of an inch; its shape oval with two projecting papillæ; the integument distinct and composed of two coats, the body filled with pale round corpuscles and many oval ones. There seemed to be a mouth with a feeble current setting into it; but neither hooklets, spines, nor vibratile cilia were visible. The motions by contraction and expansion of the worm were very remarkable; and this evidence of its vitality continued two or three days after the death and putrefaction of its host.

\section{On the Myology of Chamceleon parsonii. By St. George Mivart, F.R.S.}

The singular modifications of the appendicular skeleton of the Chameleon, and the remarkable resemblances which exist between its pectoral and pelvic portions, naturally suggest that its myology cannot be other than interesting.

An unusually good opportunity of investigating that myology having, through the kindness of my friend Professor Flower, presented itself, I beg to bring before the Society the results of the dissection of a magnificent specimen of the above-named large Chameleon of Madagascar.

\section{AXIAL MUSCLES.}

\section{Muscles of the Head.}

Mylo-hyoideus anterior (figs. 1 and $3, M^{1}$ ). This muscle forms, as usual, a delicate layer which arises inside the ramus of the mandible, meeting and joining its fellow of the opposite side beneath the throat. Its fibres pass downward and backward; and its posterior portion overlaps and is superficial to the antero-inferior part of the posterior mylo-hyoid.

Mylo-hyoideus posterior (figs. 1 and $3, M^{2}$ ). A considerable but delicate muscular lamella arises from the inner side of the suspensorium of the mandible, and, passing downwards beneath the throat, meets its fellow of the opposite side. It is immediately superficial to the genio-hyoid, but anteriorly it passes above the anterior mylo-hyoid, so that the fibres of the latter are superficial to it. Posteriorly this muscle gradually loses itself in the delicate fascia investing the muscles of the chest.

Above, this muscle is closely connected with a thin muscular layer which springs from the dense fascia binding down the muscles of the occipital crest, and which ends in the fascia which encloses the levator claviculæ. 
A double-bellied muscle (fig. $1, Z$ ), which might be called a superficial temporal, arises posteriorly from the anterior border of the suspensorium. It here forms a delicate sheet of fibres which converge and are implanted into a tendon which passes beneath the strong zygomatic ligament which connects the posterior margin of the orbit with the lower end of the suspensorium. Anteriorly other muscular fibres spring from the upper border of the mandible, and passing backwards are inserted into the tendon before mentioned.

Temporalis * (fig. 6, T). This muscle is of prodigious size ; and it would be interesting to know what is the use to the Chameleon of so singularly voluminous a temporal. It springs from the whole surface of the temporal fossa, and from the occipital crest, where it appears on the back of the head, having the most anterior part of the longissimus dorsi on its inner side, and the complexus on its outer side. It is inserted into the upper border of the mandible, between the coronoid process and the articular surface. I did not find any distinct masseter $\uparrow$.

The depressor mandibula (figs. 1 and 6, D), or digastric, arises from the postero-external margin of the singular occipital crest and of the suspensorium. It is inserted into the posterior end of the mandible.

The pterygoids $\ddagger$ (figs. 1,3 , and $5, P t$.) are closely united. The external pterygoid is thick and large, arising from the inner side of the much downwardly prolonged pterygoid, and being inserted into the adjacent side of the mandible, between the coronoid process and the angle of the jaw.

The internal pterygoid is much smaller, and passes from the outside of the pterygoid to the posterior part of the mandible.

\section{Muscles of the Hyoid.}

The genio-hyoid $\S$ (figs. 3, 6, and $7, G$. H.) arises from the hinder side of the mandible, at and near its symphysis. Passing backward it ends in a delicate fascia (closely connected with the under surface of the basihyal), which also receives the fibres of the sterno-hyoid, the two muscles thus forming a sheet only irterrupted by fascia.

The cerato-mandibular $\|$ (figs. 3, 6, and 7, C.M.) arises in common with the last, of which it may be considered a differentiation. It is inserted into the summit of the thyro-hyal or posterior cornu.

Levator arcuum (fig. $7, A$ ). A small muscle may perhaps be thus named which springs from the summits of the hyoidean cornua and loses itself in fascia within the lower jaw.

Cerato-hyoideus (fig. 7, $H$ ). This is a small but thick muscular

* See Cuvier, 'Lçeons d'Anat. Comp.' 1835, 2nd edition, tome iv. première partie, p. 137.

† This agrees with Meckel's observations. Anat. Comp. traduit par Sanson et Schuster, 1838, tome viii. p. 113.

$\ddagger$ Cuvier, l. c. p. 140 ; Meckel, l. c. p. 115.

\$ Cuvier, l. c. p. 531; Meckel, l. c. p. 141.

|| Cuvier, l. c. p. 531; Meckel, l.c. p. 141. 
Fig. 2 .

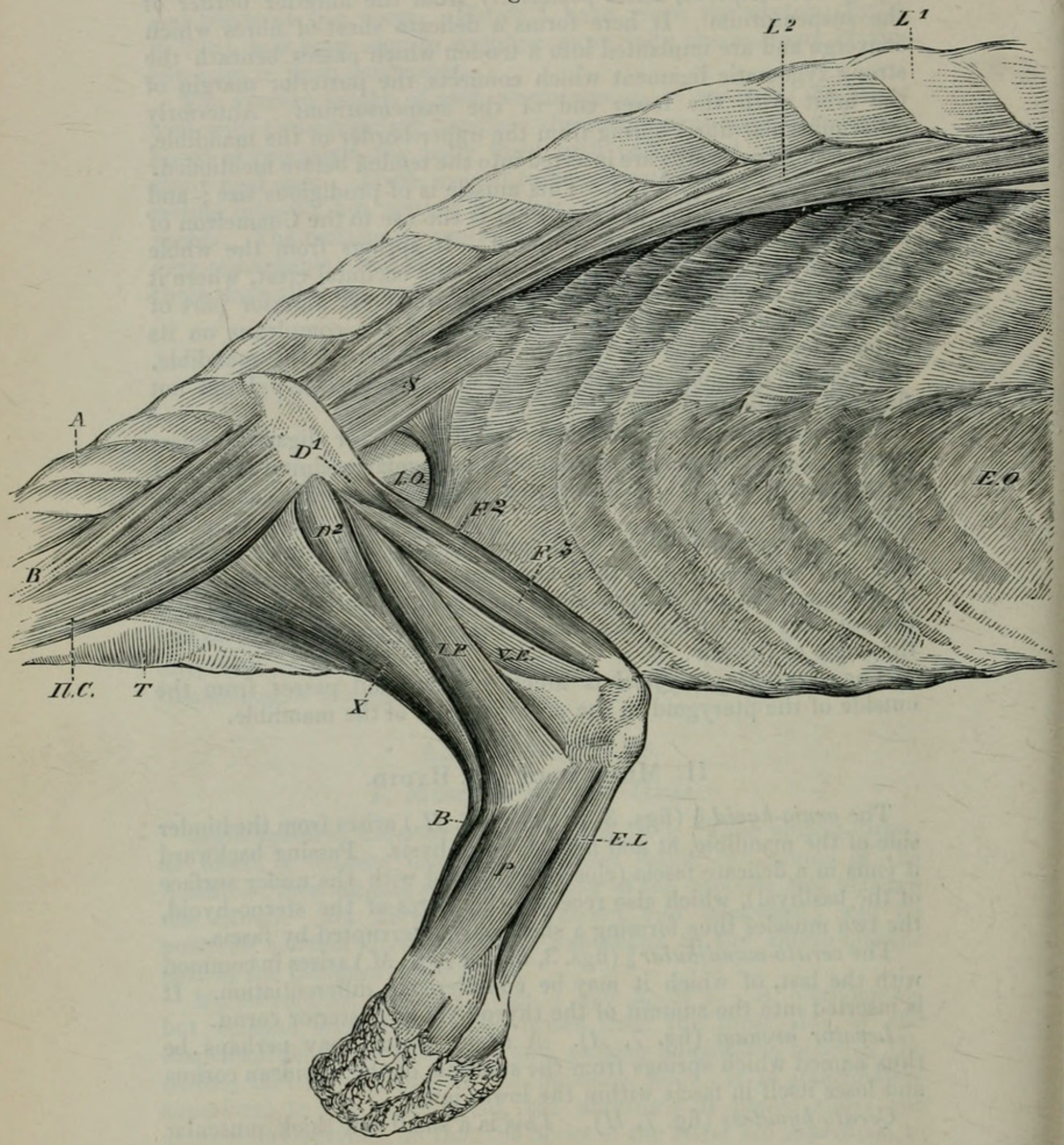

Superficial muscles.

$A B$. Supracaudal. $B$. Biceps femoris. $D^{\mathrm{l}}$. Gluteus primus. $D^{2}$. Gluteus secundus. E. L. Extensor longus digitorum. E. O. External oblique. $F^{2}$, $F^{3}$. Rectus femoris. Il. C. Ilio-caudal. I. O. Internal oblique. I.P. Ilioperoneal. $L^{1}, L^{2}$. Longissimus dorsi. $P$. Peroneus. $S$. Sacro-lumbalis. T. Transversus perinei, $V . E$. Vastus externus. X. Gluteus maximus. 
Fig. 1.

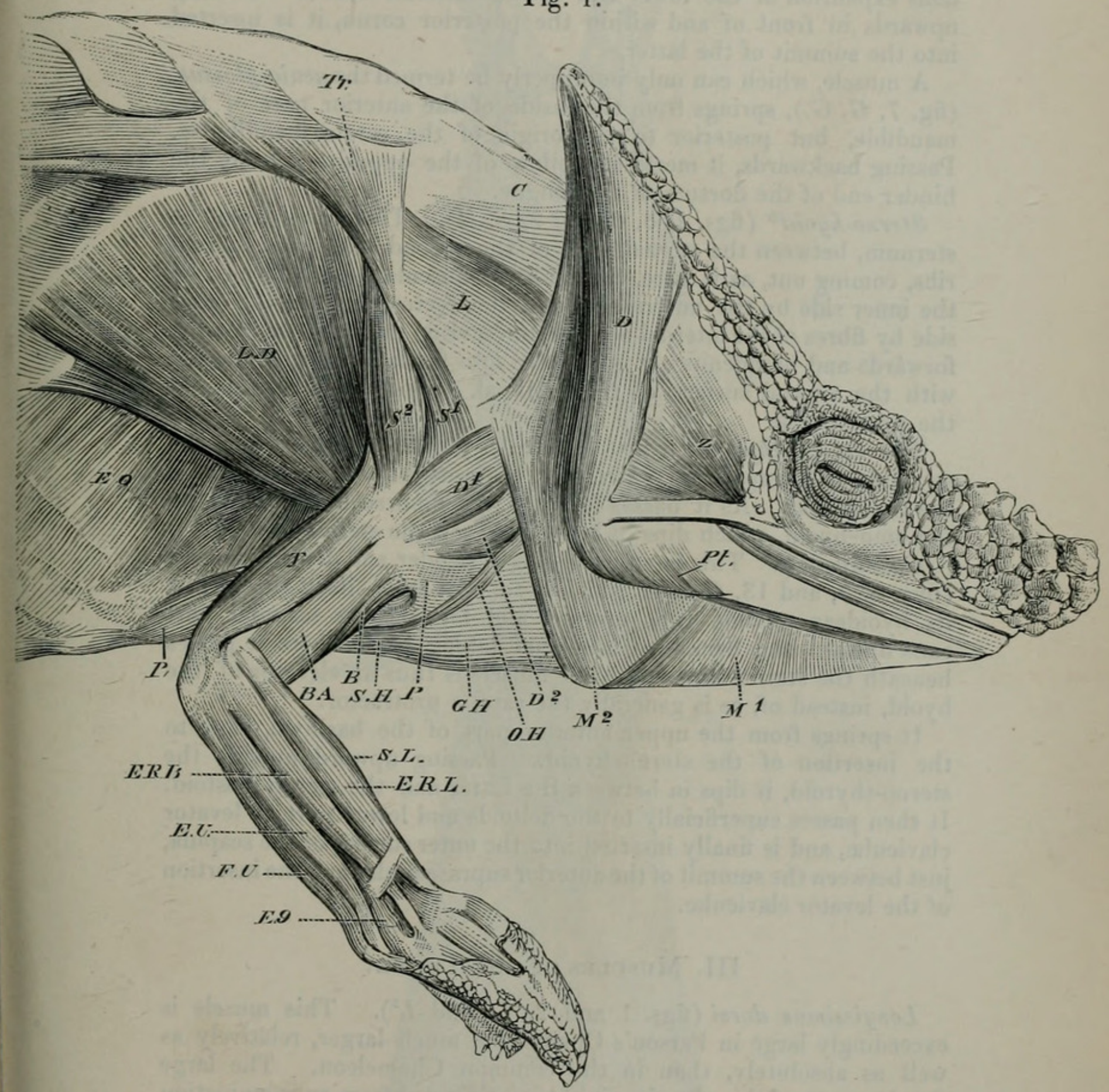

Superficial muscles.

B. Biceps. B.A. Brachialis anticus. C. Complexus. D. Digastric. $D^{1}, D^{2}$. Deltoid. $E^{9}$. Small extensor 9. E. O. External oblique. E. R. B. Extensor radialis brevior. E. R. L. Extensor radialis longior. E. U. Extensor ulnaris. $F . U$. Flexor ulnaris. G. H. Genio-hyoid. $L$. Levator claviculæ. L. D. Latissimus dorsi. $M^{1}$. Mylo-hyoid anterior. $M^{2}$. Mylohyoid posterior. O.H. Omo-hyoid. P. Pectoralis. Pt. Pterygoid. $S^{1}$, $S^{2}$. Suprascapulars. S. H. Sterno-hyoid. S.L. Supinator longus. T. Triceps. Tr. Trapezius. Z. Superficial temporal. 
mass which arises from the basihyal within the cup-like cartilaginous expansion of the lower end of the anterior cornu. Passing upwards in front of and within the posterior cornu, it is inserted into the summit of the latter.

A muscle, which can only improperly be termed the genio-glossus, (fig. $7, G$. G.), springs from the inside of the anterior part of the mandible, but posterior to the origin of the cerato-mandibular. Passing backwards, it meets its fellow of the opposite side at the hinder end of the dorsum of the tongue.

Sterno-hyoid* (figs. $1,3,6$, and $7, \boldsymbol{S} . \boldsymbol{H}$ ). This arises from the sternum, between the sternal ends of the second and third sternal ribs, coming out, as it were, from a little muscular pouch formed on the inner side by the anterior end of the rectus, and on the outer side by fibres of the internal oblique, or external intercostals. Passing forwards and broadening, it is inserted into fascia closely connected with the ventral surface of the basihyal, opposite the insertion of the genio-hyoid.

The sterno-thyroid $\dagger$ (figs. 6 and $7, T$. H.) springs from the sternum, and, expanding anteriorly, is inserted into the summit of the thyro-hyal. As it passes forward it is embraced externally by the omo-hyoid, which dips in between it and the sterno-mastoid.

Omo-hyoid $\ddagger$. This is an exceedingly slender and delicate muscle (figs. 6,7 , and $13, O . H$.), which is so bent upon itself that, while its hyoidean portion runs upward and forward, its scapular part runs upward and backward, the bend taking place where it passes beneath the sterno-mastoid. The muscle is thus an elevator of the hyoid, instead of, as is generally the case, a protractor.

It springs from the upper anterior part of the basihyal, close to the insertion of the sterno-hyoid. Passing upward outside the sterno-thyroid, it dips in between the latter and the sterno-mastoid. It then passes superficially to the deltoids and lower part of levator claviculæ, and is finally inserted into the outer surface of the scapula, just between the summit of the anterior suprascapular and the insertion of the levator claviculæ.

\section{Muscles of the Trunk.}

Longissimus dorsi (figs. 1 and 2, $L^{1}$ and $L^{2}$ ). This muscle is exceedingly large in Parson's Chameleon, much larger, relatively as well as absolutely, than in the common Chameleon. The large development of this muscle might be anticipated from an examination of the skeleton; for not only are the neural spines much prolonged, but the articular processes (zygapophyses) are so produced as to simulate (if they are not rather homologous with) the metapophyses of the Mammalia.

This large muscular mass is pretty clearly divisible into a larger upper and a smaller inferior portion.

* Cuvier, l. c. p. 532 ; Meckel, l. c. p. 136.
† Cuvier, l. c. p. 532 ; Meckel, l. c. p. 136.
† Cuvier, l. c. p. 532 ; Meckel, l. c. p. 136. 
Fig. 3 .

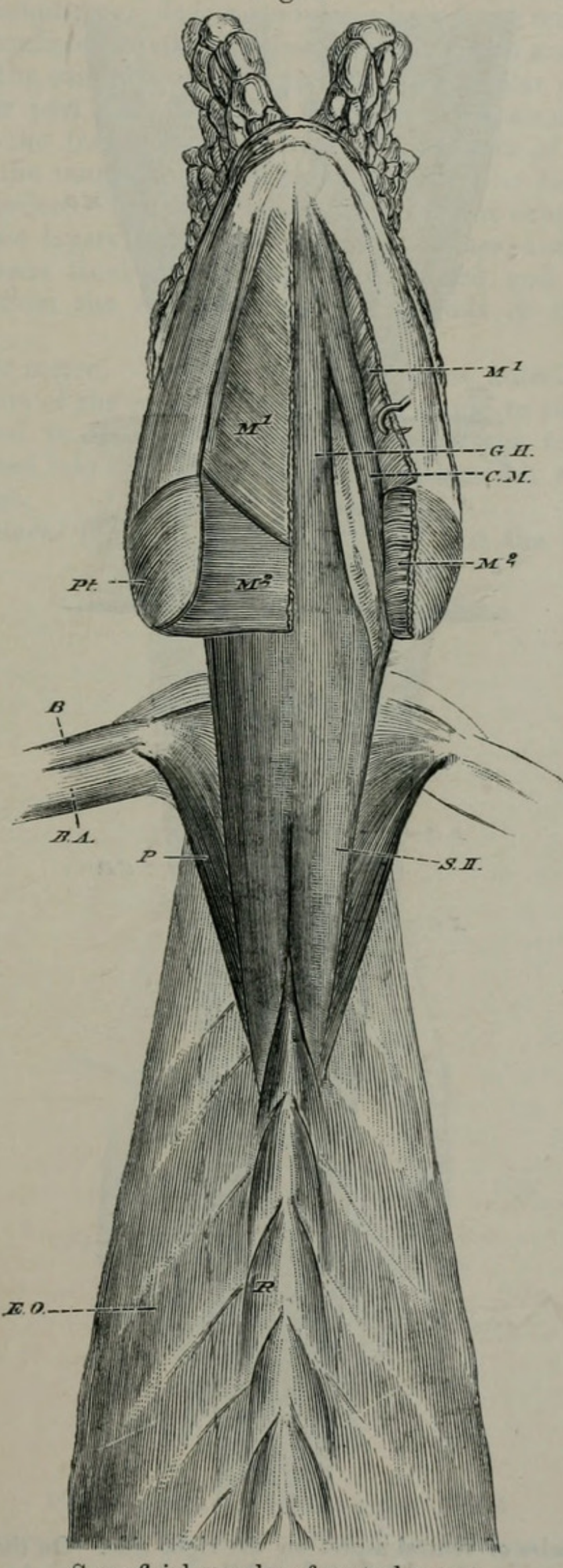

Superficial muscles of ventral aspect.

B. Biceps. B.A. Brachialis anticus. C.M. Cerato-mandibular. E. O. External oblique. G.H. Genio-hyoid. $M^{1}$. Mylo-hyoid anterior. $M^{2}$. Mylo-hyoid posterior. P. Pectoralis. Pt. Pterygoid. R. Rectus. S. $H$. Sterno-hyoid.

Proc. Zool. Soc.-1870, No. LVII. 
Fig. 4 .

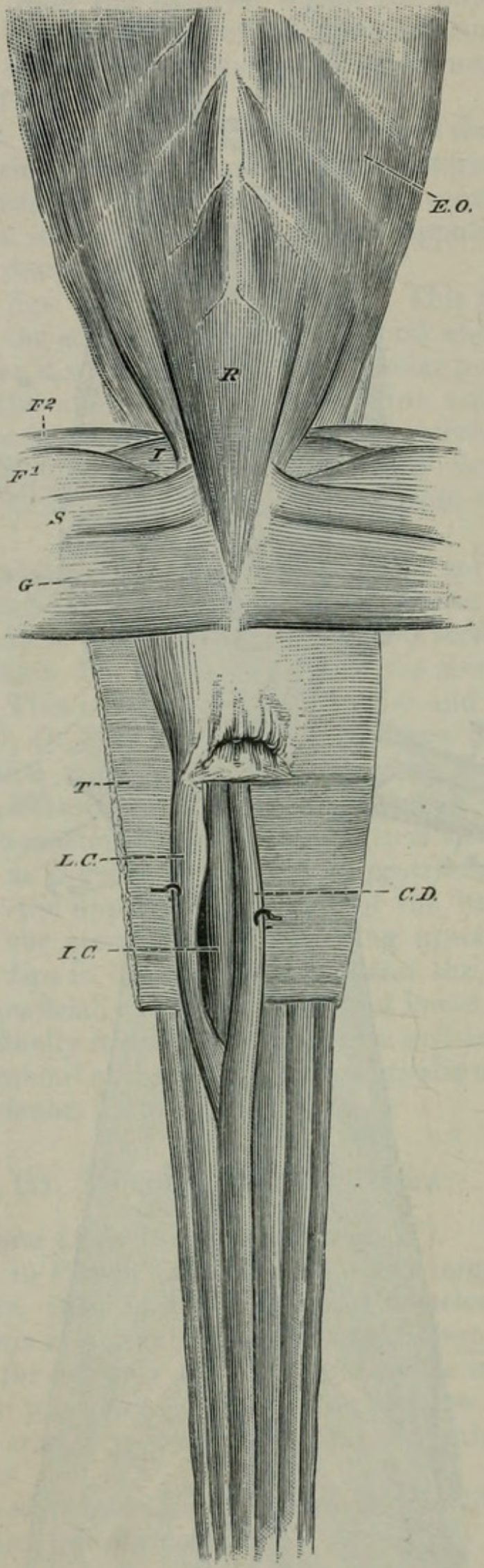

Superficial muscles of ventral aspect on the right side. On the left the transversus perinei is cut and reflected, and the ischio-caudal shown by the separation of the adjacent muscles.

C.D. Infero-caudal. E. O. External oblique. $F^{1}, F^{2}$. Rectus femoris. $G$. Gracilis. I. Iliacus. I. C. Ischio-caudal. L. C. Cloacal muscle. $R$. Rectus. S. Tibial adductor. T. Transversus perinei. 
The upper part $\left(\boldsymbol{L}^{1}\right)$ occupies the groove between the neural spines and the zygapophyses. It is bound down by a dense tendinous fascia, and shows tendinous thickenings passing downward and slightly forward, from the summits of the spines to the articular processes.

The lower part $\left(L^{2}\right)$ occupies the groove between the zygapophyses and the transrerse processes, and consists of a number of cones, with the muscular apices posterior and the tendinous aponeuroses anterior. Thus the muscle on being cut exhibits a number of aponeurotic layers placed one within the other, and shows externally tendinous thickenings, passing backward and very slightly downward, from the zygapophyses to the ends of the transverse processes.

Complexus major. This is merely the most anterior portion of the upper part of the longissimus dorsi. Passing to the back of the skull, internal to the postero-superior part of the temporal, it is deeply inserted into the side of the cranium, beneath the projecting occipital crest.

The complexus minor (figs. 1,6 , and $7, C$ ) is the most anterior

Fig. 5 .

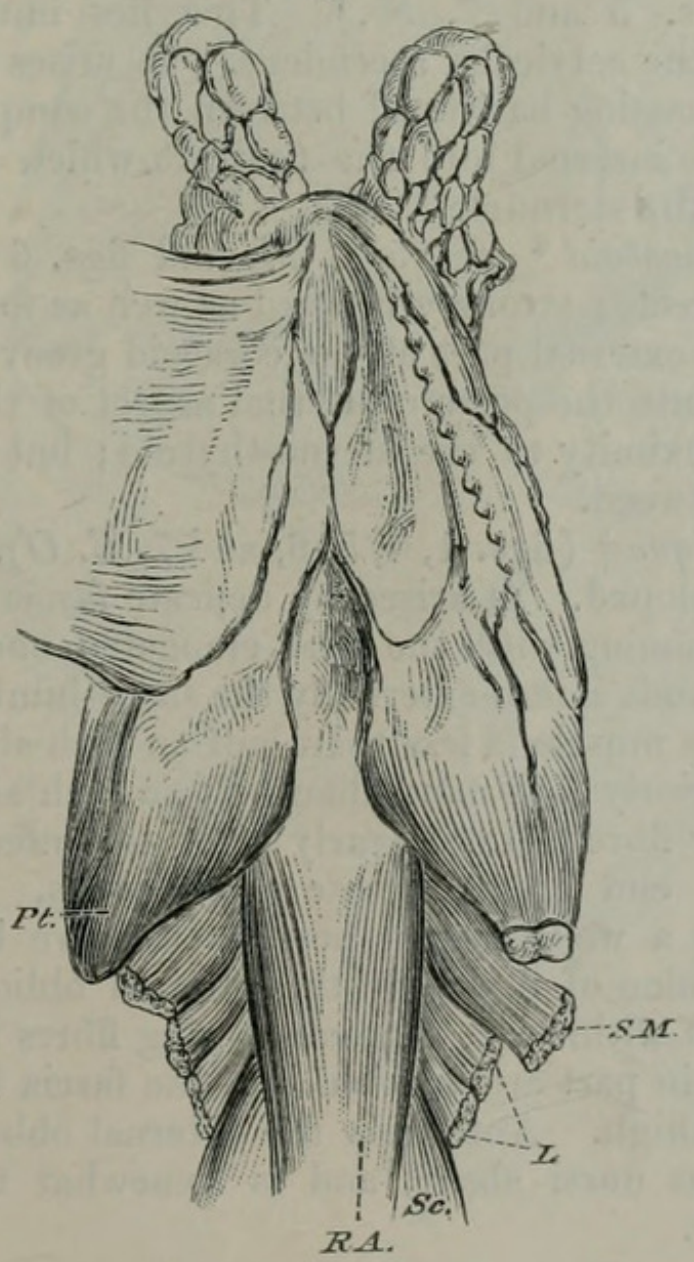

Deepest muscles of ventral aspect of neck.

L. Levator claviculæ. Pt. Pterygoid. R.A Rectus anticus. Sc. Scalenus, S. $M$. Sterno-mastoid. 
portion of the lower part of the longissimus dorsi. Diverging outward it is implanted into the postero-internal aspect of the suspensorium, and into the back of the skull. At its insertion this muscle has the postero-superior part of the temporal at its inner side, and the upper part of the depressor mandibulæ at its outer side. It is also implanted above and internal to the attachment of the sterno-mastoid.

Sacro-lumbalis (fig. $2, S$ ). This muscle arises from the dense fibrous tissue in which the ilium is more or less imbedded. Thence its fibres pass forward, being conterminous below with the origin of the external oblique, and conterminous above with the inferior margin of the lower part of the longissimus dorsi. Anteriorly this muscle becomes very indistinct, being with difficulty separable from the similarly directed fibres of the external intercostals. Passing forward beneath the latissimus dorsi, the trapezius, and the levator claviculæ, it ends by constituting the muscle next described.

Cervicalis ascendens (fig. 7, C.A ). This is the continuation forward of the sacro-lumbalis. It is connected with the ribs and transverse processes of the more anterior vertebræ, and is inserted into the atlas.

Scalenus (figs. 5 and $7, S c$.). This lies immediately on the ventral side of the cervicalis ascendens. It arises from the side of the atlas, and, passing backward between the complexus minor and rectus anticus, is inserted into the first rib which is elongated but does not reach the sternum.

The sterno-mastoid* (fig. 5, S. M, and figs. 6 and $7, S t . M$ ) is short, and is directed strongly upward as well as forward. It arises from the antero-external part of the coracoid groove of the sternum, and is inserted into the postero-internal aspect of the suspensorium. It is in close proximity to the sterno-thyroid; but the narrow omohyoid passes between.

External oblique $\dagger$ (figs. 1, 4, 5, 6, and $7, E . O$ ). This muscle is not largely developed. It arises by delicate fascia from the outside of the ribs (beginning with the first elongated one), at the line of fascia which bounds infero-externally the sacro-lumbalis. Anteriorly the origin of the muscle is less than half an inch above the angles of the ribs; posteriorly it is more than half an inch above them.

The muscular fibres do not nearly reach the inferior middle line of the body, but end in a delicate aponeurosis. Posteriorly this muscle ends in a well-marked border (concave backwards), thus allowing the tendon of origin of the internal oblique to come into view behind and within it. The converging fibres in part unite with the rectus, and in part are inserted into the fascia binding down the muscles of the thigh. Anteriorly the external oblique is overlapped by the latissimus dorsi above, and is somewhat blended with the pectoralis below.

* Meckel, l.c. p. 282.

+ Meckel (l. c. p. 287) says the abdominal muscles of the Chameleon are exceptionally feeble and simple. They are so; but in $C$. parsonii they are more developed (relatively as well as absolutely) than in the common Chameleon. 
1870$.

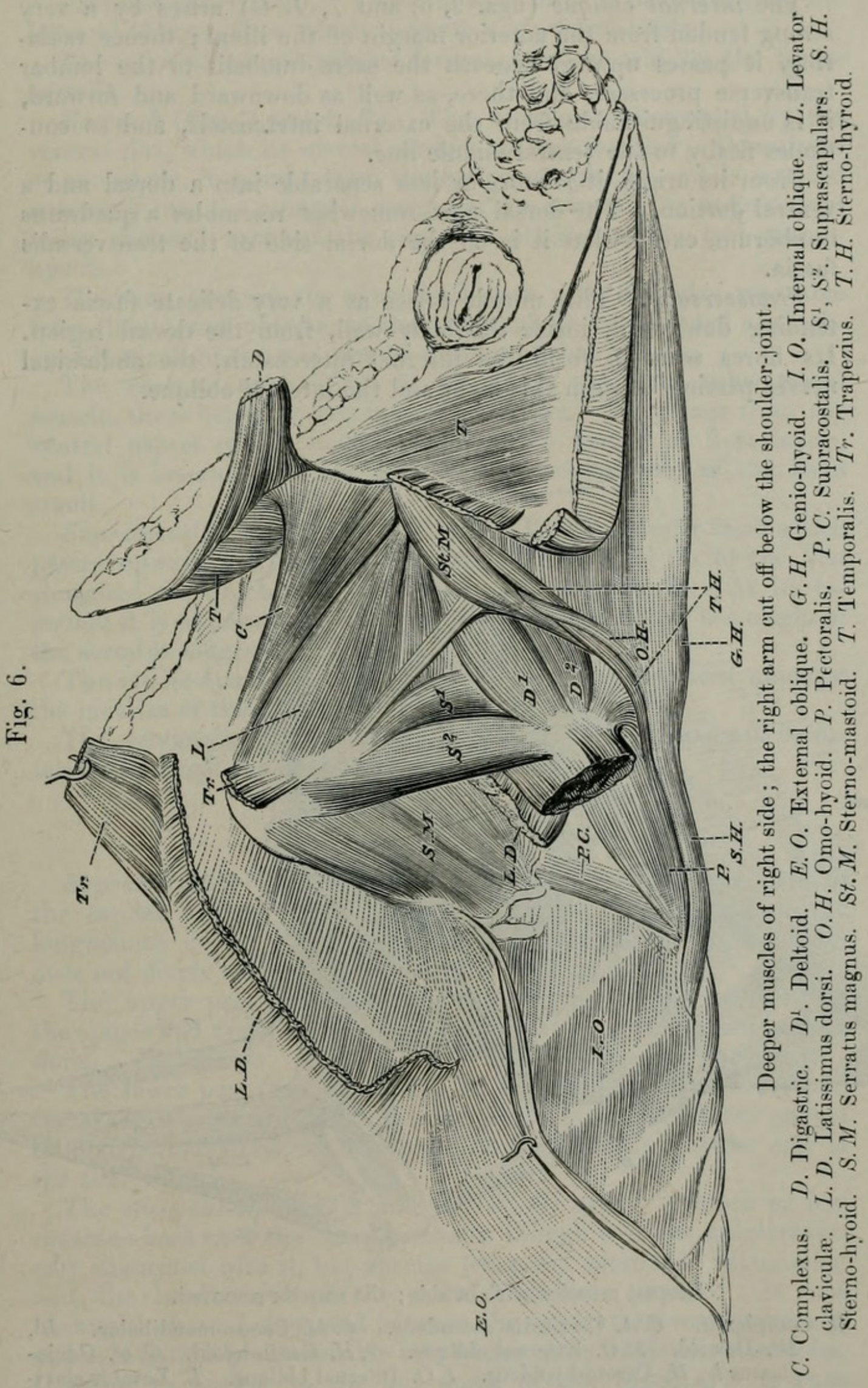


The internal oblique (figs. 2, 6, and $7, I . O$ ) arises by a very strong tendon from the anterior margin of the ilium; thence radiating, it passes upward beneath the sacro-lumbalis to the lumbar transverse processes, and there, as well as downward and forward, it is undistinguishable from the external intercostals, and so continues fleshy to the ventral middle line.

From its origin, it is more or less separable into a dorsal and a ventral portion. The dorsal part somewhat resembles a quadratus lumborum, except that it is on the dorsal side of the transversalis fascia.

Transversalis. This muscle arises as a very delicate fascia extending downward, inside the body-wall, from the dorsal region. Its fibres seem to form the internal intercostals, the abdominal nerves passing between this layer and the internal oblique.

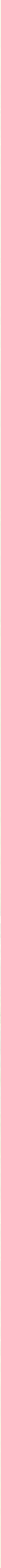


External intercostals. These muscles seem to be formed by the internal oblique, from which they are undistinguishable.

The internal intercostals are formed, as above said, by the transversalis.

Rectus * (figs. 3 and $4, R$ ). This muscle is interrupted by the ventral ribs, which its several portions connect together. Considered as one whole, it springs from the pubic symphysis, and is inserted anteriorly into the posterior margin of the sternum, its anterior end being enclosed between the posterior origins of the two sternohyoids.

The parts between the ventral ribs are with difficulty separable from the internal oblique, so that they might be regarded as thickened fasciculi of the mid-ventral portion of that muscle.

The rectus anticus (fig. $5, R . A$ ) is the only subvertebral muscle, there being no retrahentes costarum. It springs from the ventral aspect of the bodies of about the first 8 or 9 vertebræ, and it is inserted into the side of the occipital part of the basis cranii.

Supracostalis (figs. 6 and $7, P . C$ ). This is a fleshy band which passes upward and forward from the third sternal rib to the first elongated rib, which is in front of the first sternal rib. At its insertion it is conterminous with the most ventral part of the origin of the serratus magnus.

The sterno-hyoid and sterno-thyroid have been noticed amongst the muscles of the hyoid.

The pectoralis, latissimus dorsi, and sterno-coracoid will be described amongst the appendicular muscles.

\section{Muscles of the Tail.}

Supracaudal. The muscles which occupy the upper half of the caudal surface are the direct continuations backward of the longissimus dorsi. The continuation is direct, because the ilium does not divide them, but is superficial to them.

The upper part (figs. 2 and $27, A$ ) occupies the greove between the spines and zygapophyses, like the upper part of the longissimus dorsi.

The lower part (figs. 2 and $27, B$ ) occupies the groove between the zygapophyses and the transverse processes, like the lower part of the longissimus dorsi. These muscles are continued to the end of the tail.

The ilio-caudal (figs. 2 and 27, Il. C) seems to more or less continue backward the sacro-lumbalis, though it is not uninterruptedly connected with it, but springs from the sacro-iliac attachment and the hinder side of the sacral transverse process. It runs backward above, below, and between the caudal transverse processes, and is indistinctly subdivisible into two or more longitudinal muscles. It seems to answer to the ilio-caudal of the Urodelat. It runs

* Meckel, $l$. c. p. 287.

+ See P. Z. S. 1869 , pp. 268 and 463. 
backward to the end of the tail, and, except toward the root of that organ, furms fully half of each lateral caudal mass.

Fig. 8 .

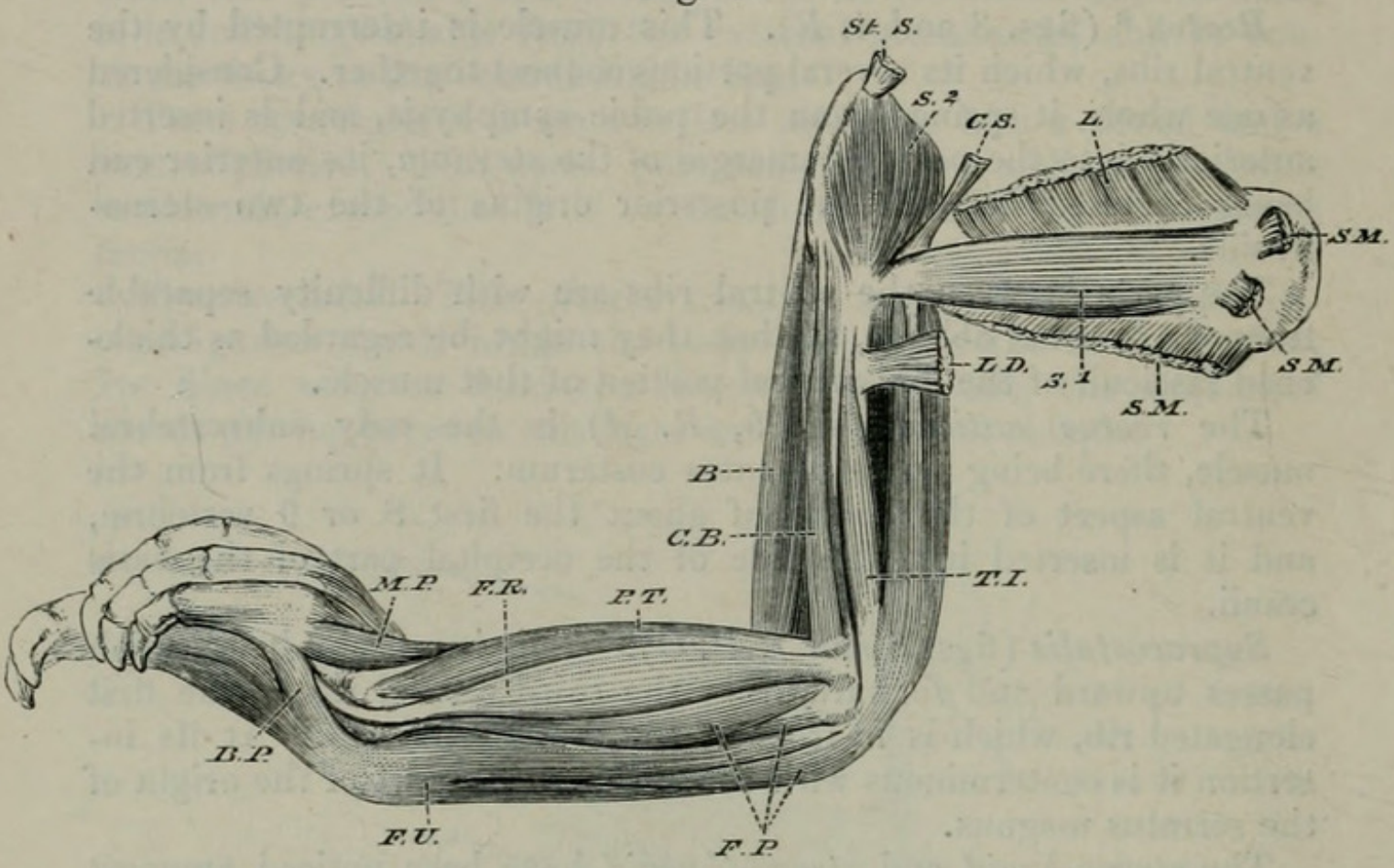

Inner side of right pectoral limb.

B. Biceps. B. P. Flexor brevis pollicis. C.B. Coraco-brachialis. C.S. Costocoracoid ligament. F.P. Flexor longus pollicis. $F$. R. Flexor radialis. $F$. U. F exor ulnaris. L. Levator claviculæ. L.D. Latissimus dorsi. M.P. Extensor metacarpi pollicis. P.T. Pronator teres. $S^{1}, S^{2}$. Subscapularis. S.M. Serratus magnus. St. S. Sterno-coracoid. T.I. Internal part of triceps.

Transversus perinei (figs. 4 and $27, T$ ). A muscle may perhaps be thus named which meets its fellow of the opposite side in the subcaudal middle line, behind the cloacal opening. Anteriorly it blends with what I provisionally distinguish as the gluteus maximus; posteriorly it loses itself in a delicate fascia enclosing the inferocaudal.

Infero-caudal (figs. 4 and 27,C.D). This muscle runs along the middle of the under surface of the tail for its whole length, passing, anteriorly, above the transversus perinei, and beside the cloacal aperture internal to the ischio-caudal. It ends on the postero-external wall of the cloaca.

The ischio-caudal (figs. 4 and 27, I. C) springs from the under part of the postsacral caudal vertebræ (from about the fourth to the twelfth), side by side with its fellow of the opposite side of the tail. .Passing forward within the cloacal muscle, it is inserted into the tuberosity of the ischium.

The cloacal muscle (figs. 4 and $27, L . C$ ) arises from beneath the tail, about the twelfth postsacral vertebra. It passes forward 
above the infero-caudal, outside the ischio-caudal, but within the lateral caudal. It is inserted into the hinder lip of the cloaca.

The femoro-caudal will be described amongst the muscles of the pelvic limb.

Fig. 9.

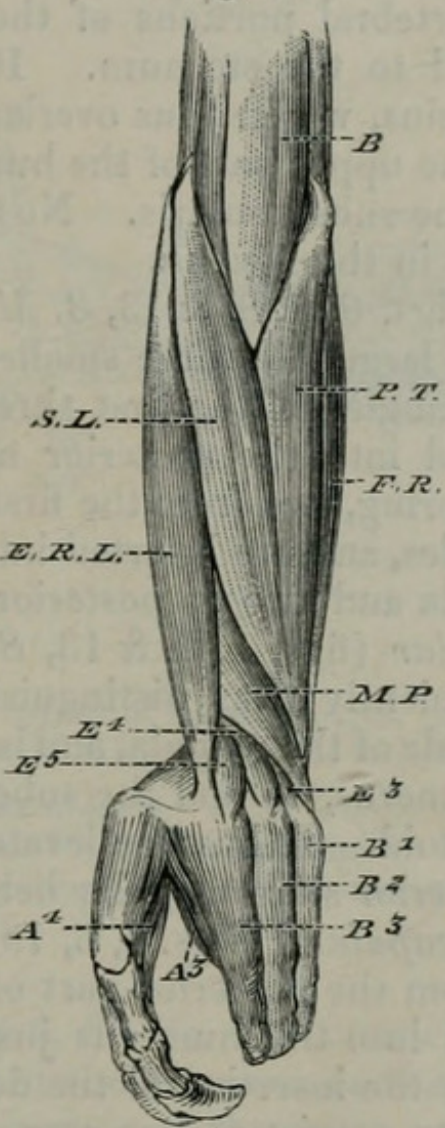

Radial side of right arm.

$A^{3}$. Adductor digiti terti. $A^{4}$. Adductor digiti quarti. $B$. Biceps. $B^{1}, B^{2}, B^{3}$. Extensores phalangorum. $E^{3}, E^{4}, E^{5}$. Extensores metacarporum. E. R.L. Extensor radialis longior. F.R. Flexor radialis. M.P. Extensor metacarpi pollicis. P. T. Pronator teres. S. L. Supinator longus.

\section{APPENDICULAR MUSCLES.}

\section{Muscles of the Pectoral Limb.}

Pectoralis* (figs. 1,3 , and $13, P$ ). This rather narrow but fleshy muscle arises from the sternum (partly within but mostly behind the origin of the sterno-mastoid), from the third sternal rib, and from the fascia of the external oblique. It is inserted into the anterior aspect of the radial tuberosity of the humerus, just external to the tendon of the biceps. Its most anterior part is superficial to the infero-median portion of the subclavius or epicoracohumeral.

The trapezius $\uparrow$ (figs. 1, 6, 13, Tr.) is an exceedingly small muscle, which arises from a strong fascia attached to the neural spines, from about the fifth to the seventh. Narrowing downward,

$$
\text { * Meckel, l. c. p. } 344 .
$$

+ Meckel, l. c. p. 310. 
it is inserted into the anterior part of the outer surface of the scapula, near its summit, between the insertions of the levator claviculæ and posterior suprascapular.

Latissimus dorsi (figs. 1, 6, 8, L. D). This rather large muscular sheet springs from the strong fascia which binds down the erector spinæ, and from the vertebral portions of the third and fourth of those ribs which extend to the sternum. Its origin extends forward beneath the trapezius, which thus overlaps it. It is inserted into the ulnar side of the upper part of the humerus, a little distance below the insertion of the subscapularis. No tendon passes down on its inner side, as it does in the Iguana.

Serratus magnus* (figs. $6,7,8, \& 13, S . M$ ). This is much divided, consisting of one large and three smaller portions. The first springs from about the angles of the first three ribs which join the sternum, and is inserted into the posterior margin of the scapula. The other three parts spring, two from the first rib, and one from the second, above their angles, and are inserted into the inner side of the upper part of the scapula and into its posterior margin.

Anterior suprascapular (figs. 1, 6, \& $13, S^{1}$ ). A muscle which may perhaps be conveniently thus distinguished springs from the anterior part of the outside of the scapula, and is strongly iuserted outside the head of the humerus, behind the subclavius, and in front of the insertion of the deltoid. It has the levator claviculæ and omohyoid in front, the posterior suprascapular behind.

The posterior suprascapular + (figs. $1,6,13, S^{2}$ ) is a thick fleshy muscle, which arises from the posterior part of the outer side of the scapula, and is inserted into the humerus just above (behind when the humerus is vertical) the insertion of the deltoid.

The deltoid appears to consist of two parts. The upper or posterior portion (figs. $1,6,7, \& 13, D^{1}$ ) arises from the inner end of the ventral margin of the coracoid groove of the sternum, just external to the origin of the second part of the deltoid, and internal to and overlapped by the sterno-mastoid. Some fibres arise from the spur of the epicoracoid. Passing down superficially to the subclavius, it is inserted into the head of the humerus, between the insertions of the pectoralis and of the second part of the suprascapular.

The second, lower or anterior part of the deltoid (figs. 1, 6, 7, \& $13, D^{2}$ ) arises from the innermost part of the ventral margin of the coracoid groove of the sternum, just within the origin of the first part of the deltoid. It is inserted into the humerus above the summit of the brachialis anticus, and on the antero-inferior side of the insertion of the first part of the deltoid. It is superficial to part of the subclavius; and its antero-inferior margin is conterminous with the upper border of the most anterior part of the pectoralis.

Omo-hyoid. This muscle has been described amongst the others which belong to the hyoid.

Subscapularis (fig. 8, $S^{1} \& S^{2}$ ). This large muscle consists of two distinct parts. One arises from the whole costal surface of the ossified part of the scapula, between the insertions of the levator clavi* Meckel, l. c. p. 313 .

+ Meckel, l.c. p. 342 . 
culæ and serratus magnus. The other part arises from the whole inner surface of the coracoid. Both parts have a common insertion into the ulnar tuberosity, which is close to the head of the humerus.

Fig. 10.

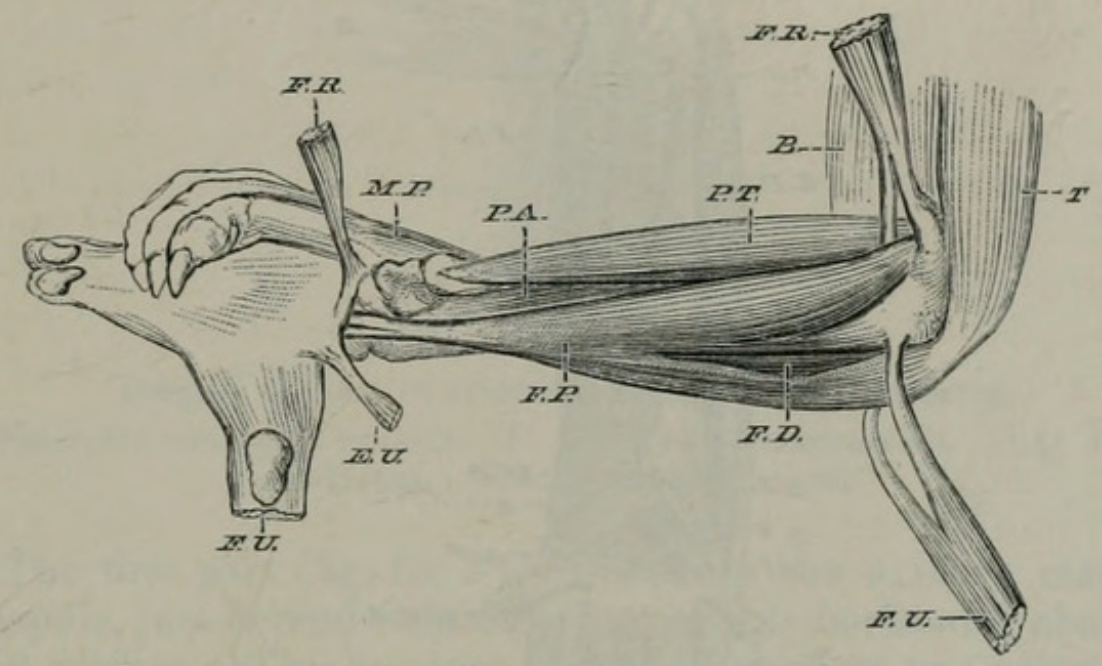

Deeper muscles of flexor aspect of right forearm, the flexor ulnaris and flexor radialis being eut and reflected.

Biceps. E. U. Extensor ulnaris. F. D. Flexor profundus digitorum. F.P. Flexor longus pollicis. $F . R$. Flexor radialis. $F . U$. Flexor ulnaris. M.P. Extensor metacarpi pollicis. P.A. Pronator accessorius. P. T. Pronator teres. T. Triceps.

Sterno-coracoid (fig. 8, St. S). A muscle, as in the Iguana, takes origin from the inside of the sternum, and is inserted, very strongly, into the antero-internal angle of the inner surface of the precoracoid, just external to its articulation with the sternum.

A dense membrane is attached, on the one hand, to the anterior margin of the first rib, on the other hand into the angle of the anterior margin of the shoulder-girdle, between the two parts (fig. 8, $C . S$ ) of the subscapularis. This sheet of membrane appears to represent the costo-coracoid muscle of the Ignana.

The levator clavicula (figs. $1,5,6,7,8,13, L$ ) is a very voluminous and more or less double mass. It arises from the basioccipital, and is inserted into the anterior margin of the scapula, overlapped by the omo-hyoid, and conterminous behind with the suprascapular.

Subclavius (fig. 13, S. C). This muscle, which I before named * epicoraco-humeral, but which Professor Rolleston considers to be the subclavius, springs from the whole anterior border of the coraco-epicoracoid. Passing downward and backward beneath the deltoid, it is inserted into the great tuberosity of the humerus, immediately in front of (above, the humerus being vertical) the insertion of the pectoralis, which muscle is superficial to it. The subclavius itself is superficial to the antero-external part of the short coraco-brachialis, with which (especially toward its hinder part) it is closely connected.

$$
\text { * P. Z. S. } 1867 \text {, p. } 778 .
$$


Fig. 11.

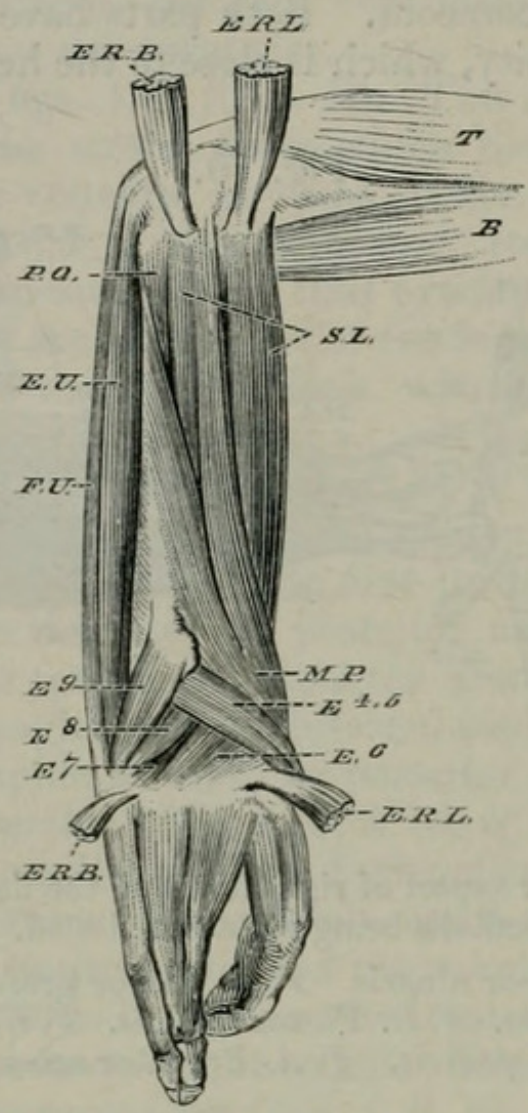

Deeper muscles of extensor aspect of right forearm, the extensores radiales longior and brevior being eut and reflected.

B. Biceps. $E^{4}-E^{9}$. Extensores metacarporum. E. R. B. Extensor radialis brevior. E.R.L. Extensor radialis longior. E. U. Extensor ulnaris. F. U. Flexor ulnaris. M.P. Extensor ossis metacarpi pollicis. P.Q. Pronator quadratus. S.L. Supinator longus. T. Triceps.

Coraco-brachialis * (fig. 8, C.B). This muscle consists of two parts :-

1. The first of these, or shorter portion, is a broad muscle like that of the Iguana. It arises, by muscular fibres, from the whole outer surface of the coracoid. It is inserted into the radial tuberosity of the humerus, and into about the upper two-fifths of the shaft of that bone, ending below in a point which extends between the innermost origin of the brachialis anticus and the most antero-external origin of the external part of the triceps.

2. The second, longer portion, arises by a strong but rather delicate tendon from the outer margin of the posterior end of the sternal groove of the coracoid. Long and slender, it passes downward, and is inserted, by muscular fibres, into the internal condyle.

Triceps $\dagger$ (figs. $1,8,10,11, \& 13, T, T I, T^{2}$ ). This muscle only consists of three parts; and the second and third of these are very closely united. 
Fig. 12.

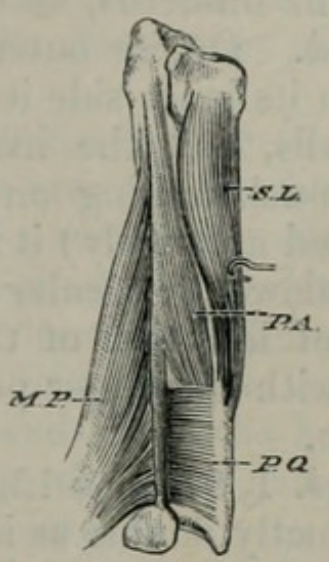

Deepest muscles of extensor surface of right forearm.

M. P. Extensor metacarpi pollicis. P.A. Pronator accessorius. P. Q. Pronator quadratus. S. L. Supinator longus.

1. The first part (fig. 13, $T$ ) arises from the axillary margin of the scapula, just behind (when the humerus is horizontal, above) the glenoid surface. This answers to both of the first two parts (external and internal long heads) of the triceps of the Iguaua; and a strong tendon on its inner surface indicates the part answering to the internal long head of that muscle in the last-named animal.

2. The second part arises from the whole posterior surface of the humerus and part of its outer and inner surfaces. Its origin extends upward (the humerus being placed vertically) to just below the head of the bone, and above the insertion of the second part of the deltoid. Inwardly it extends to just behind the insertion of the latissimus dorsi. Externally (fig. 13, $T^{2}$ ) it reaches the posterior border of the brachialis anticus.

3. The third part (fig. 8, T.I) is much the smallest, and is closely connected with the second part. It springs from the inside of the humerus, its origin rising to the level of the upper limit of the insertion of the latissinus dorsi.

These three parts unite togetber, and are inserted in common into the proximal end of the ulna, a large sesamoid ossicle being situated, behind the elbow, in the tendon of insertion.

The biceps (figs. $1,8,9,10,11,13,15, \& 16, B$ ) has a single origin, by a long and strong tendon, from the coracoid, just external to its sternal groove. This tendon is at first covered by fibres of the subclavius, and then passes over the short coraco-brachialis. Descending in front of the insertion of the pectoralis, it there becomes fleshy, and becomes more or less divisible into two bellies, which embrace the brachialis anticus in front, but leave part of the latter visible within and without the arm. It ends in two tendons, one for each belly (fig. 16, B), which, by their divergence, expose the brachialis anticus in the middle of the lower part of the upper arm. One of these tendons is inserted into the ulnar side of the front aspect of the radius, at the place of the tubercle; the other is inserted into the ulna, in front of its articular surface for the humerus. 
The brachialis anticus (figs. $1,13,16, B . A$ ) occupies the whole antero-external aspect of the humerus, extending upward as far as the insertion of the deltoid. On its outer side it has the external head of the triceps; and on its inner side it has the biceps, the short part of the coraco-brachialis, and the insertion of the pectoralis. Passing downward (and much uniting on its ulnar side with the biceps, which wraps it round anteriorly) it is inserted into the flexor surface of the ulna, just below its articular surface for the humerus, and between the tendons of insertion of the biceps. Its insertion is conterminous (fig. 16) with the upper part of the ulnar origin of the flexor longus digitorum.

Supinator longus* (figs. 1, 9, 11, \& 15, S.L). This muscle is very large, but not so distinctly double as in the Iguana. Its more superficial portion arises from the external condyle, and is inserted into the outer side of the radius for almost its whole length. Its deeper portion springs from quite the lower end of the humerus, external to its articulation with the radius. It is inserted into the upper half of the extensor surface of the radius.

The superficial part is closely connected, toward and at its origin, with the extensor carpi radialis longior, but is separated from it distally by the extensor ossis metacarpi pollicis. Ulnad it is conterminous with the insertion of the pronator teres. The deeper part is not only intimately united with the extensor carpi radialis longior, which covers it, but also with the long part of the extensor ossis metacarpi pollicis.

Fig. 13.

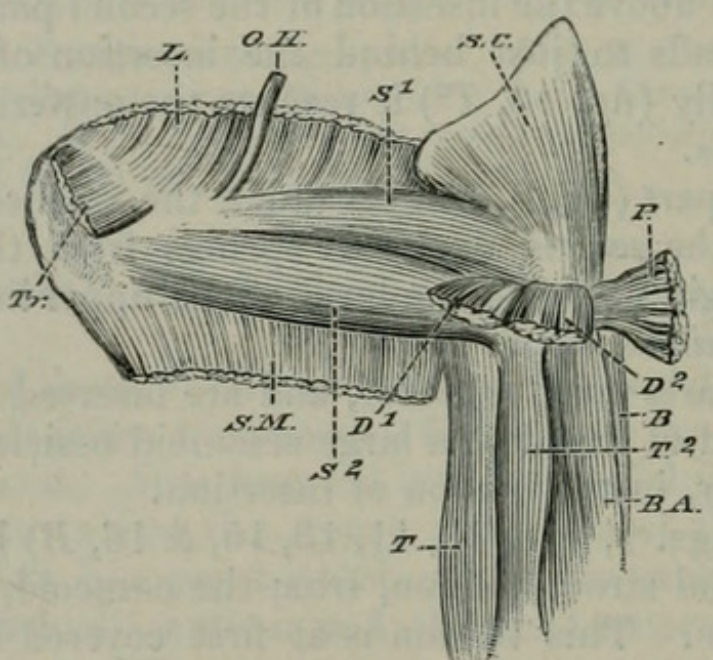

Outer surface of right scapula and upper arm.

B. Biceps. B. A. Brachialis anticus. $D^{1} \& D^{2}$. Deltoid. L. Lrvator claviculæ. O. H. Omo-hyoid. P. Pectoralis. $S^{1} \& S^{2}$. Suprascapulars. S. $C$. Subelavius. S.M. Serratus magnus. T. \& $T^{2}$. Triceps. Tr. Trapezius.

Extensor carpi radialis longior $\dagger$ (figs. 1, 9, \& 11, E.R. L). This muscle arises by tendinous fibres from the outer surface of the external condyle superficially to the long portion of the supinator longus,

* Meckel, l.c. p. 367 .

† Meckel, l.c. p. 381. 
with which, for some distance, it is very intimately connected. Passing distad, and quite separating from the extensor carpi radialis brevior, it is inserted into the distal part of the dorsum of the third metacarpal bone.

The extensor carpi radialis brevior (figs. $1 \& 11, E . R . B$ ) arises from the lower end of the external condyle, and from the humerus, quite close to the articular surface for the radius, and outside the origin of the deeper part of the supinator longus, with which, for some distance, it is intimately connected. Passing distad, and diverging from the extensor carpi radialis longior, it passes under a very strong tendinous arch (which extends from the lower end of the ulna to the radius), and is inserted into the ulnar side of the distal part of the dorsum of the fourth metacarpal.

Extensor carpi ulnaris * (figs. 1, 10,\& 11,E.U). This arises by a tendon which is common to it and to the larger (or radial) portion of the flexor carpi ulnaris. This tendon is attached (beneath the tendon of insertion of the triceps) to the back of the humerus, almost at its distal extremity. The muscle ends distally in a strong tendon, which, dipping down beneath that of the flexor carpi ulnaris, is inserted into the proximal part of the palmar surface of the fifth metacarpal and of its externally projecting process.

Pronator teres $\uparrow$ (figs. $8,9,10,14, \& 15, P . T$ ). The round pronator is very large, and arises by a strong tendon from the internal condyle, close to the insertion of the long part of the coraco-brachialis. It is inserted into about the lower four-fifths of the radius, toward its outer border.

The flexor carpi radialis (figs. $8,9,10, \& 14, F . R$ ) has a double origin. One tendon is from the internal condyle immediately below the origin of the pronator teres. The other tendon of origin springs from near the same spot as the first, but separated from it by the summit of part of the flexor profundus digitorum, which is thus embraced between these two tendons. The inner tendon is also much connected with the capsule of the joint between the humerus and ulna, so that it has the appearance of bifurcating. The muscle ends below in a strong tendon, which, passing down, with the flexor sublimis of the palm superficial to it, is inserted into the proximal end of the palmar surface of the first metacarpal, and thence runs on to the same part of the fifth metacarpal, thus constituting a palmar arch, beneath which the long flexor tendons run.

Pronator accessorius (figs. 10, 12, 14, 15, \& 16, P.A). A thick muscle, which seems to answer to the muscle I have thus named in the Iguana $\ddagger$, arises from the internal condyle, immediately beneath and within the humeral origin of the flexor profundus digitorum. It also arises from the radial border of the ulna and from the interosseous ligament, coming into view, when the deepest layer of the extensor surface is exposed (fig. 12), above the short pronator quadratus. It is inserted into rather more than the lower two-thirds of the flexor aspect of the radius (between the insertions of the pronator teres and

* Meckel, l. c. p. 383.

+ Meckel, l.c. p. 368.

‡ See P.Z. S. 1867 , p. 784 . 
the pronator quadratus), and into the radial carpal ossicle, into which are especially inserted the fibres from the interosseous ligament.

Pronator quadratus* (figs. $12 \& 15, P . Q$ ). This is small, and confined to the lower part of the forearm. It springs from the radial aspect of the ulna and from the lower part of its flexor surface, with the pronator accessorius superficial to it on the flexor aspect of the arm. It is inserted into the flexor aspect of the radius for about its distal fourth, but it does not go to the radial ossicle. It is altogether a transverse layer running directly from the ulna to the radius.

Flexor carpi ulnaris (figs. $1,8,10, \& 11, F . U$ ). This muscle is much more distinct from the flexor carpi radialis than it is in the Iguana. It has a double origin-one from the internal condyle, the other (by a tendon common to it and the extensor carpi ulnaris) from the lower end of the back of the humerus. Passing downward, the two parts unite, but, before doing so, leave exposed one part of the flexor profundus digitorum, as another part of that muscle comes to the surface between the flexor ulnaris and flexor radialis. It is inserted into the palmar ossicle, and therefore superficially to the tendon of the extensor carpi ulnaris.

Fig. 14.

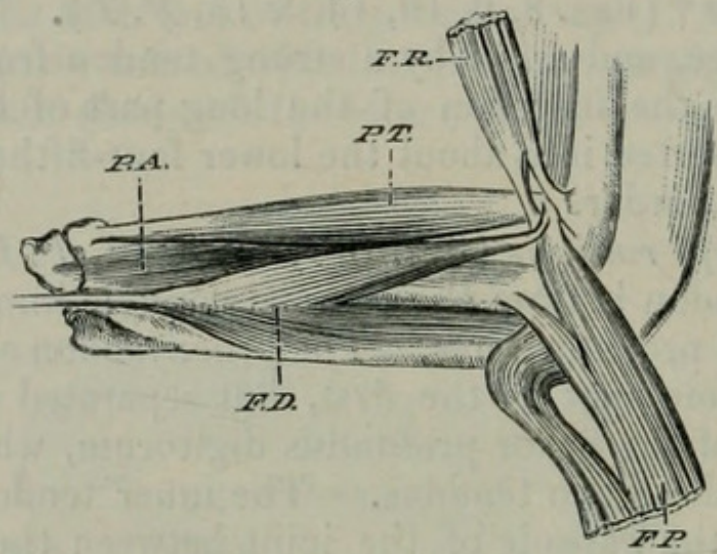

Deeper flexor surface of right forearm.

$F . D$. Flexor profundus digitorum. F.P. Flexor longus pollicis. F.R. Flexor radialis. P.A. Pronator accessorius. P. T. Pronator quadratus.

Flexor longus pollicis (figs. $8,10, \& 28, F . P$ ). This large muscle has three distinet origins. The first is from the internal condyle, between the two tendons of origin of the flexor carpi radialis. The second is from the internal condyle, below the first head of origin. These two parts soon unite to form one belly. The third head of origin springs from the olecranon and the radial aspect of the upper part of the ulna. It unites with the other belly about the middle of the forearm (where the ulnar nerve comes out over it), and passing distad ends in a strong tendon which divides into four, one division going to each of the three radial digits (pollex, index, and mid digit), and the fourth division uniting with that tendon of the flexor profundus digitorum which goes to the fourth digit. 
The fexor profundus digitorum (figs. 10, 14, 15, 16, \& 28, F.D) takes origin by only two heads. The first of these arises from the internal condyle in union with the similarly arising head of the flexor longus pollicis, and similarly embraced by the tendons of origin of the flexor carpi radialis. The second head springs from the radial side of the olecranon, and from the radial aspect of the ulna for about its upper three-fourths, its summit being contiguous (fig. 16) to the ulnar side of the insertion of the brachialis anticus. The two parts of the muscle having united about the middle of the forearm, it extends distad, and ends in a strong tendon which passes in a deep groove at the distal end of the ulna, and side by side with the tendon of the flexor longus pollicis. The tendon then bifurcates. The radial bifurcation very soon receives a short slip from the ulnar bifurcation, then a long slip from the flexor longus pollicis (its fourth and most ulnad tendon), and finally a long and very delicate slip, one more from the ulnar bifurcation. It then goes to the fourth digit. The ulnar bifurcation gives first a very short, and then a long and very delicate slip to the radial bifurcation, and then goes to the fifth digit.

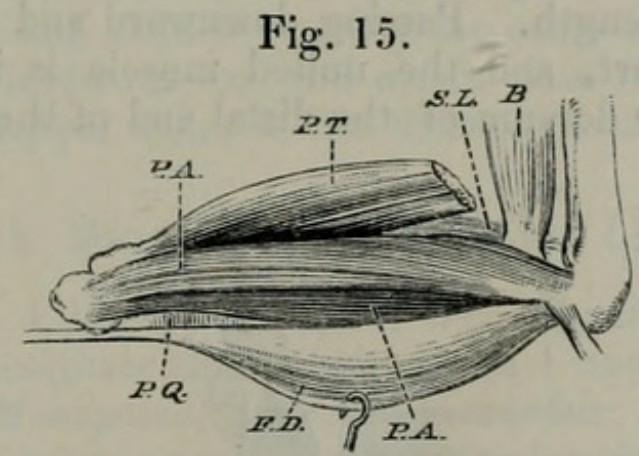

Deepest flexor surface of right forearm.

B. Biceps. F. D. Flexor profundus digitorum. P.A. Pronator accessorius. P.Q. Pronator quadratus. P. T. Pronator teres. S. L. Supinator longus.

Lumbricales (fig. 28). There are three lumbrical muscles in the hand.

The first of these arises from the ulnar side of the long flexor tendon of the fourth digit, and goes to the same side of the same digit.

The second arises from the radial side of the long flexor of the fourth digit, and goes to the same side of the same (fourth) digit.

The third arises from the ulnar side of the long flexor tendon of the third digit, and goes to the same (ulnar) side of the same (third) digit.

Flexor brevis digitorum. This muscle is confined entirely to the hand. It springs from the annular ligament which passes from the first to the fifth metacarpal, and is inserted into the digits, the long flexor tendons passing between its fibres.

Flexor brevis pollicis (fig. 8, B.P). A thick, short muscle which may perhaps be thus named arises from the palmar ossicle and annular ligament, and is inserted into the radial margin of the

Proc. Zool. Soc.-1870, No. LVIII. 
pollex distad and radiad of the insertion of the extensor ossis metacarpi pollicis.

Flexor brevis minimi digiti. Another small muscle arises from the ulnar side of the palmar ossicle, and is inserted into the ulnar side of the fifth digit.

Adductor digiti tertii (fig. 9, $A^{3}$ ). This springs from the ligament connecting the third and forth metacarpals, and is inserted into the ulnar side of the third digit.

Adductor digiti quarti (fig. 9, $A^{4}$ ). Another small muscle arises from the same ligament, connecting the third and fourth metacarpals, and is inserted into the radial side of the fourth digit.

The extensores metacarporum are very numerous, but are all short muscles, except the one which goes to the pollex.

Extensores I. and II. or extensor ossis metacarpi pollicis* (figs. $8,9,10,1] \& 12, M . P)$. This is a very large and even a double muscle, like the homotypal muscle of the pes. The longer part arises (in intimate connexion with the deeper part of the supinator longus) from the lower end of the humerus, close to its articulation with the radius. Passing downward, it joins the shorter part a little above the wrist. This shorter part springs from the radiad aspect of the ulna for its whole length. Passing downward and radiad, it unites with the longer part, and the united muscle is inserted into the radial aspect of the dorsum of the distal end of the first metacarpal bone.

Fig. 16 .

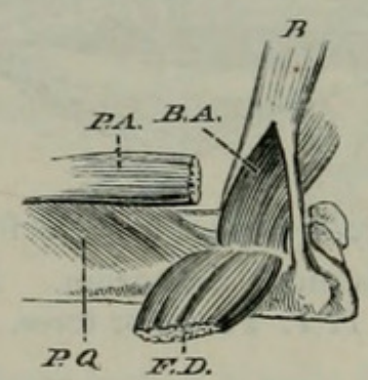

Part of deepest flexor surface of right forearm.

B. Biceps. B.A. Brachialis anticus. F.D. Flexor profundus digitorum. P. A. Pronator accessorius. P. Q. Pronator quadratus.

Extensor m. III. (fig. 9, $E^{3}$ ). This little muscle arises from the extensor aspect of the styloid process of the radius, and is inserted into the distal part of the dorsum of the first metacarpal.

Extensor $m$. $I V$. (figs. $9 \& 11, E^{4}$ ). This takes origin just beneath and beside the last-described muscle, and is similarly inserted into the second metacarpal.

The extensor $m$. $V$. (figs. $9 \& 11, E^{5}$ ) arises just beneath and beside the last described, and is similarly inserted into the third metacarpal. A few of its fibres take origin from the ulnar carpal ossicle.

The extensor $m$. VI. (figs. $9 \& 11, E^{6}$ ) springs from the central carpal ossicle, and from the dorsum of the first three metacarpals.

$$
\text { * Meckel, l.c. p. } 382 .
$$


It is inserted into the base of the fourth metacarpal. This muscle is overlapped by the extensores m. III., IV. \& V., and appears superficially (its fibres running in a contrary direction to those of the extensores last named) between the insertions of the extensor carpi radialis longior and the extensor carpi radialis brevior.

Extensor $m$. VII. (fig. 11, $E^{7}$ ). This is exceedingly small, and arises from the dorsal surface of the central carpal bone and passes to the fifth digit.

Extensor $m$. VIII. (fig. $11, E^{8}$ ). This muscle springs from the extensor surface of the ulnar carpal bone and passes to the dorsum of the fifth metacarpal.

Extensor $m . I X$. (figs. $1 \& 11, E^{9}$ ). A rather larger muscle takes origin from the ulnar side of the projecting styloid process of the ulna, and is inserted into the dorsum of the fifth metacarpal, side by side with the extensor $\mathrm{m}$. VIII.

Beside these extensors of the metacarpal bones, there are five extensors of the phalanges, extensores phalangorum (fig. $9, B^{1}, B^{2}$ $\& B^{3}$ ). Each of these passes from the dorsum of one of the metacarpals to the ungual phalanx of the same digit.

Interossei. Beside the small muscles which have been described as flexores breves and adductors, there are other small muscles, which may be termed interrosseous, and which pass from the palmar surface of the metacarpal bones to the sides of the digits.

\section{Muscles of the Pelvic Limb.}

Gracilis (figs. 4, 18, 19, 23, \& 24, G). By this name it is convenient to still designate the muscle which $I$ have already so named in the Iguana, Menopoma, and Menobronchus. Nevertheless Professor Rolleston is very possibly right in deeming it not to be the homologue of the human gracilis; yet I cannot but, remark its great resemblance to the muscle I have called gracilis of the Echidna, though freely admitting that I may have been wrong in so calling the muscle in question in that Monotreme. Whatever should be its true designation, it is very large and stout in Parson's Chameleon. It arises from the whole pubo-ischiatic symphysis, and is inserted into the tibial side of the the tibia, just below and within the internal lateral ligament.

The tibial adductor (figs. 4, 18, 19, 21, 23, \& 24, S) arises by a rather strong tendon from the brim of the pelvis, just internal to the iliacus and a little distance from the anterior end of the pubic symphysis. Continuing distad, it bifurcates just above the semitendinosus. The smaller part goes (in common with, but above, the semitendinosus) into the tibial aspect of the interarticular cartilage. The larger part goes (in common with the tendon of the semimembranosus) into the antero-peroneal aspect of the head of the tibia, passing, from behind forwards, between the tibia and fibula.

Semimembranosus (figs. 17, 23, \& 24, S. M). A muscle (which seems to answer to the second part of the muscle I have called semimembranosus in the Iguana) arises from the postero-inferior aspect 
of the tuberosity of the ischium, close to the origin of the semitendinosus, which is superficial and posterior to it. It is inserted by a long and strong tendon (in common with the peroneal part of the bifurcating tibial adductor) into the antero-peroneal aspect of the head of the tibia.

Fig. 17.

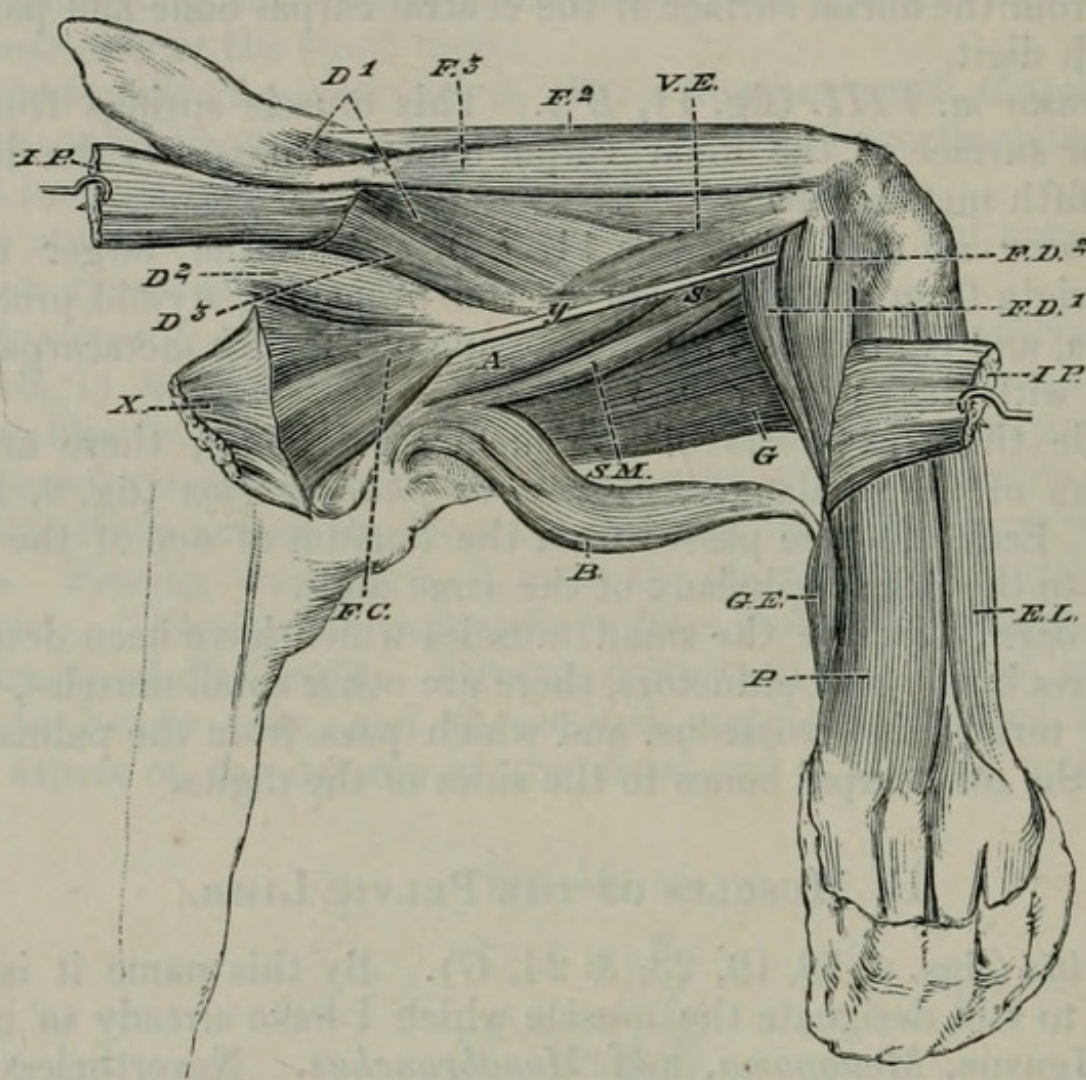

Deeper muscles of outer aspect of right pelvic limb; the ilio-peroneal cut and reflected.

A. Adductor. B. Biceps. $D^{1}$. Gluteus primus. $D^{2}$. Gluteus secundus. $D^{3}$. Gluteus tertius. E. E. Extensor longus digitorum. $F^{2} \& F^{3}$. Rectus femoris. F.C. Femoro-caudal. F. $D^{1}$. Flexor longus digitorum. F. $D^{2}$. Flexor tertius digitorum. G. Gracilis. G. E. Gastrocnemius externus. I.P. Ilio-peroneal. P. Peroneus. S. Tibial adductor. S. M. Semimembranosus. $V . E$. Vastus externus. X. Gluteus maximus. $y$. Tendon of femoro-caudal.

Semitendinosus (figs. 18, 19, 23, \& 24, S.T.). This springs, in common with the biceps, close to the tuberosity of the ischium, from the tendinous ilio-ischiatic arch, just behind the origin of the semimembranosus. Crossing beneath the tibial adductor, it is inserted into the tibial aspect of the interarticular cartilage, in common with (though below) the smaller (tibial) branch of the bifurcating tibial adductor. This may, perhaps, be the muscle which Professor Rolleston considers to be the gracilis.

Biceps (figs. 2, 17, 18, 23, \& 24, B.). This muscle takes origin from the before-mentioned ilio-ischiatic tendinous arch, close opposite to and more or less continuous with the gluteus maximus. Passing downward to the calf of the leg, it is inserted, by a tendon, 
between the distal ends of the gastrocnemii, into the peroneal aspect of the plantar ossicle. It has the gastrocnemius internus superficial to it, and is itself superficial to the gastrocnemius externus.

Fig. 18.

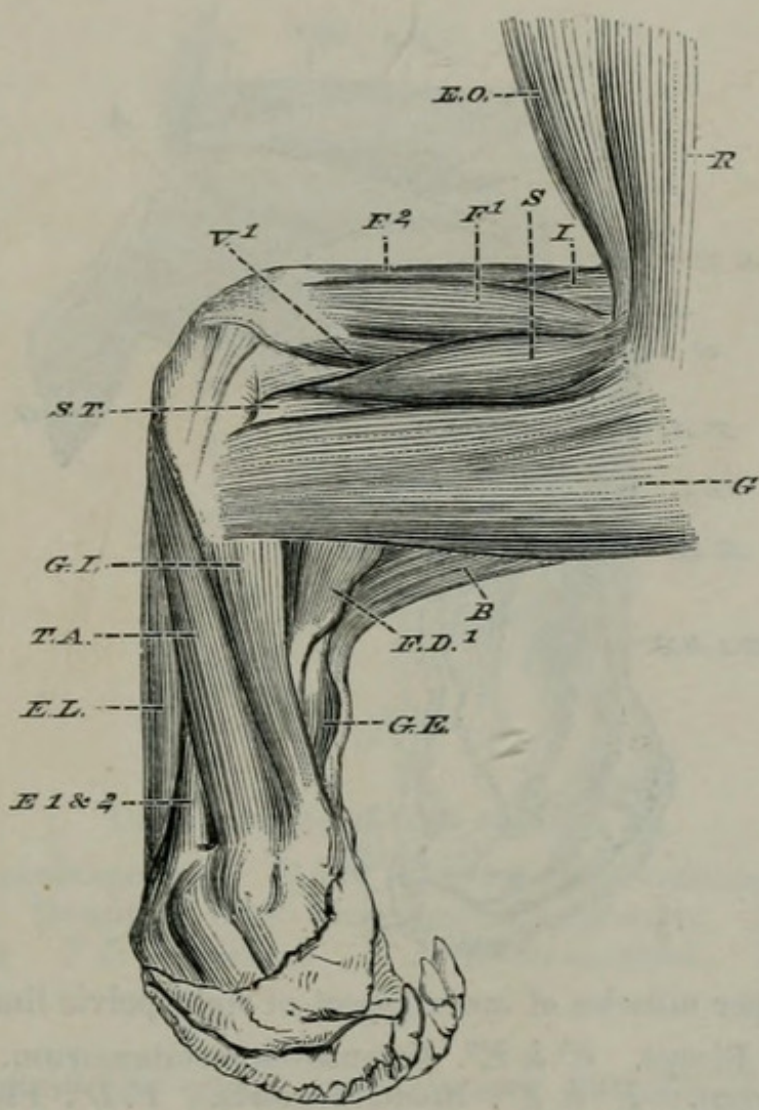

Inner side of right pelvic limb.

B. Biceps. E. L. Extensor longus digitorum. $E^{1} \& E^{2}$. Extensores metatarsorum. E. $O$. External oblique. $F^{1} \& F^{2}$. Rectus femoris. $F . D^{1}$. Gluteus primus. G. Gracilis. G. E. Gastrocnemius externus. I. Iliacus. S. T. Semitendinosus. T. A. Tibialis anticus. V.I. Vastus internus.

The ilio-peroneal (figs. 2, 17, 19, 20, 23, \& 24, I. P) arises from the outside of the ilium, just behind and more or less beneath the origin of the third part of the rectus femoris. Passing distad, and greatly expanding, it is inserted outside the leg into the posterior margin of the fibula between the peroneus and the tibialis posticus. It covers in the great sciatic nerve.

The iliacus (figs. $4,18,19,21, \& 22, I, I^{1}, I^{2}, I^{3}$ ) is more or less divisible into three parts.

The first part takes origin from the inside of the ilium, below the tendon of origin of the internal oblique.

The second part extends far back, springing from the inside of the ischium.

The third and smallest part arises from just inside the pubis, but only extends a very little on the visceral surface of the pelvis.

These three parts join together, and are inserted together into the 
upper part of the shaft of the femur, passing beneath what I have distinguished as the first part of the gluteus medius, and just below and slightly tibiad to the insertion of what $I$ have called gluteus minimus.

Fig. 19 .

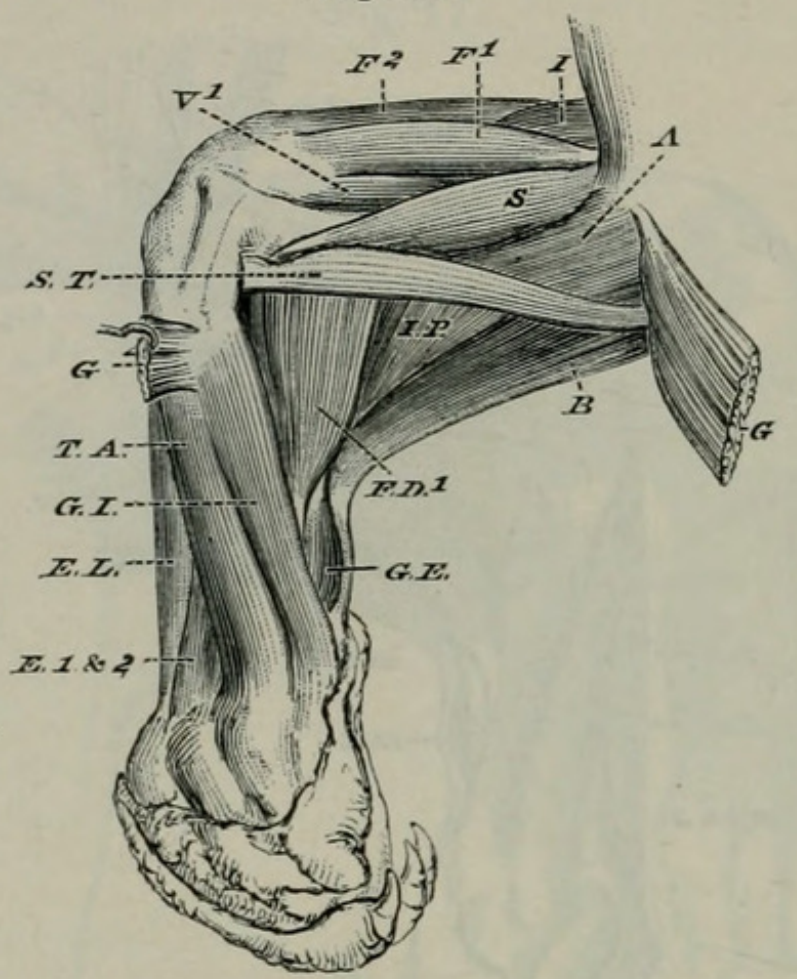

Deeper muscles of inner aspect of right pelvic limb.

A. Adductor. B. Biceps. $E^{1} \& E^{2}$. Extensores metatarsorum. E. L. Extensor longus digitorum. $F^{1} \& F^{2}$. Rectus femoris. $F \cdot D^{1}$. Flexor longus digitorum. G. Gracilis. G.E. Gastrocnemius externus. G.I. Gastrocnemius internus. I. Iliacus. I. P. Ilio-peroneal. S. Tibial adductor. S. T. Semitendinosus. T. A. Tibialis anticus. $V^{1}$. Vastus internus.

Gluteus maximus (figs. $2,17, \& 27, X$ ). This name has been applied by me in the Iguana*, Menopoma $\dagger$, and Menobranchus $\ddagger$, to a muscle which, on further consideration, seems to me can have little claim to it. On the other hand, I think that the muscle which I called pyriformis in the Iguana $\S$, answers to the one I am now about to describe in the Chameleon, and which has a considerable resemblance to that which I designated as gluteus maximus in theEchidna\|. It arises, in Parson's Chameleon, from the transverse processes of the more anterior caudal vertebræ, and is inserted into the tendinous arch which passes from the posterior margin of the ilium to the tuberosity of the ischium. It is blended posteriorly with the transversus perinei, and, but for the tendinous arch, would be continuous with the biceps, thus strongly resembling the gluteus maximus of the Echidna.

* P.Z.S. 1867 , p. 791.

$\ddagger$ P. Z. S. 1869, p. 464.
II Trans. Linn. Soc. vol. xxv. 1866, p. 391, pl. 53. figs. 2, 9, $m x$.
† P.Z.S. 1869 , p. 270.

§ P.Z.S. 1867 , p. 793 , fig. 15, P.f. 
Femoro-caudal (figs. 17, 24, \& $2 \pi, F . C \& y$ ). This is large and fleshy, and arises beneath the transverse processes of the four caudal vertebræ behind the sacral vertebræ. The anterior and smaller part of this muscle is somewhat separate, and folded over the hinder and larger part. The muscle is in part inserted into the

Fig. 20 .

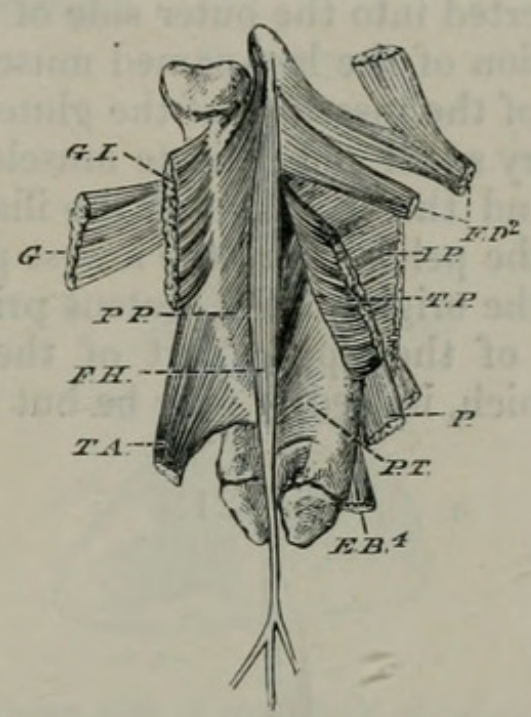

Deep muscles of back of right leg.

E. $B^{4}$. Extensor phalangorum. F. $D^{2}$. Flexor tertius digitorum. F. H. Flexor hallucis. G. Gracilis. G.I. Gastrocnemius internus. I. P. Mlio-peroneal. P. Peroneus. PP. Popliteus. P.T. Peroneo-tibial. T.P. Tibialis pos-
ticus.

posterior aspect of the great trochanter; in part it ends in a very delicate tendon $(y)$, which runs along the outer edge of the semimembranosus, the great sciatic nerve crossing it superficially on its outer side. The tendon dips down beneath the head of the flexor tertius digitorum on one side, and the tendon of the gastrocnemius externus and the head of the flexor longus digitorum on the other. It is inserted into the posterior aspect of the interarticular cartilage, which is placed between the femur and the tibia.

Three muscles, which I cannot at present accurately determine, but which I provisionally designate as gluteus primus, gluteus secundus, and gluteus tertius, pass from the ilium to the outside of the femur.

Gluteus primus (figs. $4,17, \& 21, D^{1}$ ). This seems to answer to the muscle I have called gluteus medius in the Iguana*. It arises between two heads of the rectus femoris, from the lower part of the outer side of the ilium. Passing downwards, just in front of the gluteus tertius, and beneath the third part of the rectus femoris, it is inserted into the middle of the outer side of the shaft of the femur, between the forked origin of the vastus externus.

The gluteus secundus (figs. 17, 22, \& 27, $D^{2}$ ) springs from the postero-external surface of the ilium, having the femoro-caudal con-

$$
\text { * P. Z. S. 1867, p. } 791 .
$$


tiguous to it behind, and the ilio-peroneal in front. It is inserted into the postero-external side of the great trochanter, immediately in front of the insertion of part of the femoro-caudal, and conterminous with the hinder border of the gluteus primus.

Gluteus tertius (fig. 17, $D^{3}$ ). A small and delicate muscle, which I thus distinguish, arises from a small portion of the lowest part of the posterior margin of the ilium, beneath the origin of the gluteus secundus. It is inserted into the outer side of the great trochanter, just below the insertion of the last-named muscle, and conterminous with the upper end of the insertion of the gluteus primus.

Pectineus? A very small and delicate muscle lies hidden between the gluteus tertius and the insertion of the iliacus. It arises, just behind the brim of the pelvis, from the lowest part of the outer side of the ilium, below the origin of the gluteus primus. It is inserted into the outer side of the upper part of the femur, beneath the gluteus tertius, of which, indeed, it may be but an accessory portion.

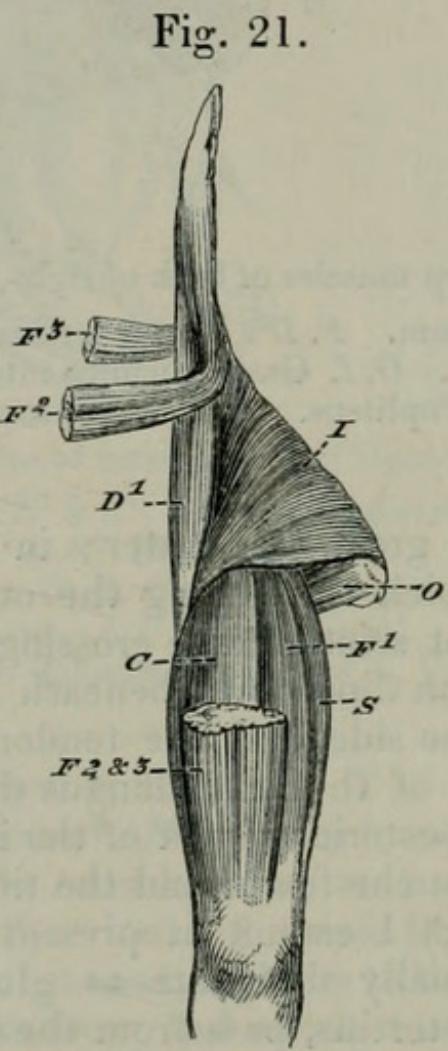

Front view of right thigh.

C. Crureus. $D^{1}$. Gluteus primus. $F^{1}, F^{2}, \& F^{3}$. Rectus femoris. I. Iliacus. $O$. Obturator externus.

Adductor (figs. 19, 23, \& 24, A). This thick muscle arises from the pelvis, at and near the ischiatic symphysis. Passing down, it is inserted into rather the outside of the shaft of the femur, below the insertion of the femoro-caudal and below and outside the insertions of the obturators. It is obscurely divided into a longer and more slender posterior part, and a thicker, shorter, more anterior portion. 
The quadratus femoris (fig. 22, $Q$ ) arises from the postero-superior side of the tuberosity of the ischium, and is inserted into the summit of the head of the femur, above the great trochanter, but more in front (i.e. on the extensor aspect) of the femur.

Obturator externus (fig. 21, O). This muscle arises from the outer surface of the ischium, and is conterminous with the quadratus femoris. It is inserted all along the great trochanter, on the inner side of the femoro-caudal.

Fig. 22 .

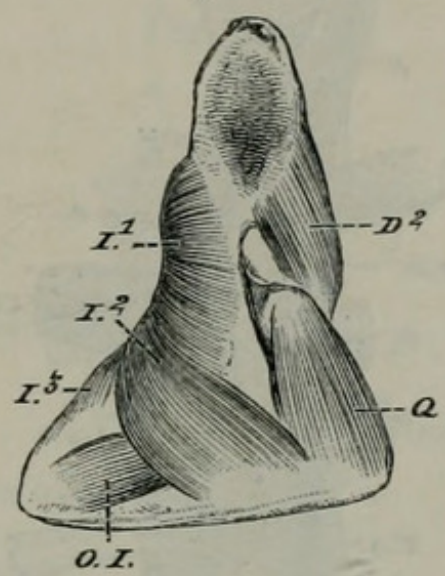

Inner side of right half of pelvis.

$D^{2}$. Gluteus secundus. $I^{1}, I^{2}, I^{3}$. Iliacus. O.I. Obturator internus.

Q. Quadratus femoris.

Obturator internus (fig. 22, O.I). This muscle arises inside the pubis, conterminous with the inner margin of the origin of the third part of the iliacus. Passing downward (through the obturator foramen, and thus becoming superficial to the second part of the iliacus), it is inserted into the femur along its posterior side down to the summit of the insertion of the adductor.

Rectus femoris (figs. $2,4,17,18,19, \& 21, F^{1}, F^{2}, \& F^{3}$ ). Three distinct muscular parts seem to belong to the category to which the rectus femoris of Mammals belongs. One of these parts seems to represent that which I have called rectus femoris in the Iguana*, and the other two parts to answer to what I have called gluteus maximus in the Iguanat.

The first part $\left(F^{1}\right)$ arises by a very strong tendon from the margin of the acetabulum.

The second part $\left(F^{2}\right)$ springs from the anterior margin of the ilium, in common with the tendon of the internal oblique.

The third part $\left(F^{3}\right)$ takes origin from the posterior margin of the ilium, between the origins of the gluteus primus and the ilio-peroneal.

Passing downward these three parts unite with the deeper extensor muscles of the thigh.

Vastus externus (figs. $2 \& 17, V . E$ ). This muscle arises from the lower half of the outer side of the femur. Distally it fuses with the other extensors.

$$
\text { * P. Z. S. } 1867 \text {, p. } 791 .
$$

+ Ibid. 
The vastus internus (fig. 19, V.I) is a rather small muscle arising from the inside of the shaft of the femur, almost down to the distal end of the bone. It blends below with the other extensors.

Fig. 23.

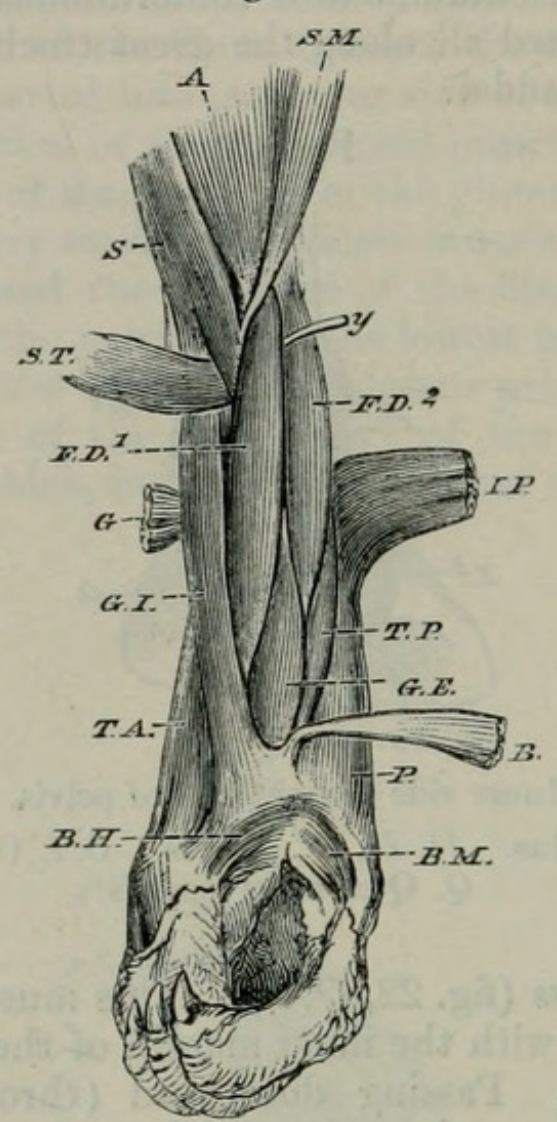

Back view of right leg.

- B. Biceps. B.H. Flexor brevis hallucis. B.M. Flexor brevis minimi digiti. $F . D^{1}$. Flexor longus digitorum. $F \cdot D^{2}$. Flexor tertius digitorum. G. Graeilis. G. E. Gastrocnemius externus. G.I. Gastrocnemius internus. I.P. Ilio-peroneal. $P$. Peroneus. $S$. Tibial adductor. $S . M$. Semimembranosus. S. T. Semitendinosus. T. A. Tibialis anticus. T.P. Tibialis posticus. $y$. Tendon of femoro-caudal.

Crureus (fig. 21, C). This is very large, but with difficulty separable from the two preceding muscles. It arises from the extensor surface of the femur, its origin extending upward to the neck of the bone on its inner aspect (passing up on the inner side of the insertion of the iliacus); fusing with the other extensors, it is inserted with them into the patella.

The gastrocnemius externus (figs. 17, 18, 19, 23, \& 24, G. E) arises by a long and strong, but delicate tendon from the posteroperoneal aspect of the interarticular cartilage. This tendon passes down between the flexor longus and flexor tertius digitorum. Rapidly broadening downward (as a fleshy mass having the gastrocnemius internus superficial to it), it is inserted into the plantar ossicle.

The gastrocnemius internus (figs. 18, 19, 20, 23, \& 24, G. I) does 


\section{$2 \mathrm{BHL}$ Biodiversity Heritage Library}

Hudson, Robert. 1870. "December 6, 1870." Proceedings of the Zoological Society of London 1870, 796-890.

https://doi.org/10.1111/j.1469-7998.1870.tb00469.x.

View This Item Online: https://www.biodiversitylibrary.org/item/90543

DOI: https://doi.org/10.1111/j.1469-7998.1870.tb00469.x

Permalink: https://www.biodiversitylibrary.org/partpdf/73761

\section{Holding Institution}

Natural History Museum Library, London

\section{Sponsored by}

Natural History Museum Library, London

\section{Copyright \& Reuse}

Copyright Status: Public domain. The BHL considers that this work is no longer under copyright protection.

This document was created from content at the Biodiversity Heritage Library, the world's largest open access digital library for biodiversity literature and archives. Visit BHL at https://www.biodiversitylibrary.org. 